\title{
DNA-Encoded Library Hit Confirmation: Bridging the Gap Be- tween On-DNA and Off-DNA Chemistry
}

Bing Xia*, G. Joseph Franklin, Xiaojie Lu, Katie L. Bedard, LaShadric C. Grady, Jennifer D. Summerfield, Eric X. Shi, Bryan W. King, Kenneth E. Lind, Cynthia Chiu, Eleanor Watts, Vera Bodmer, Xiaopeng Bai, and Lisa A. Marcaurelle*

Encoded Library Technologies / NCE Molecular Discovery, R\&D Medicinal Science and Technology, GlaxoSmithKline, 200 Cambridge Park Drive, Cambridge, Massachusetts 02140, United States

Table of Contents

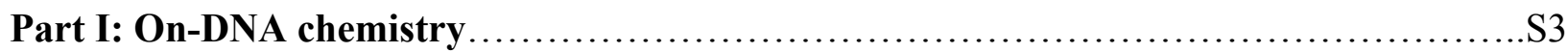

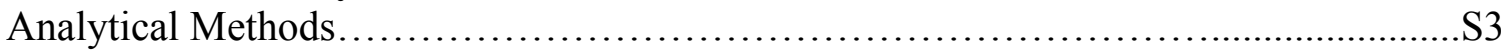

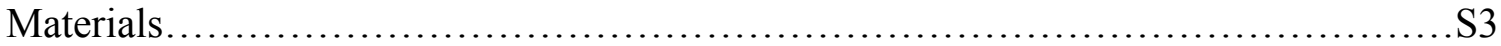

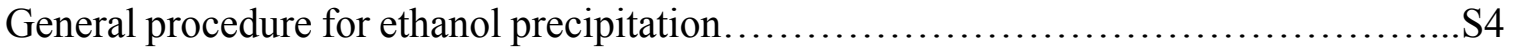

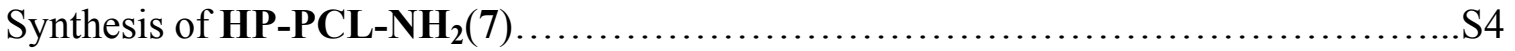

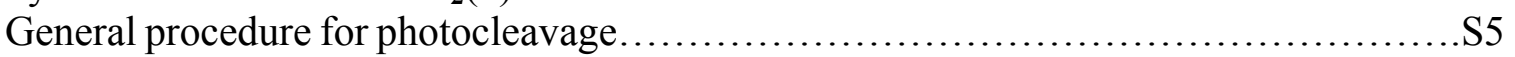

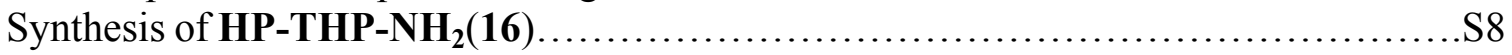

General procedure for THP cleavage................................................ 9

Case study of Photocleavable Linker (PCL) .......................................

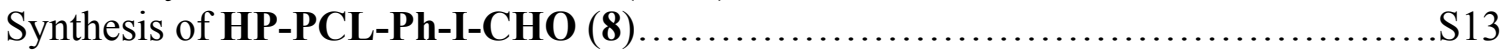

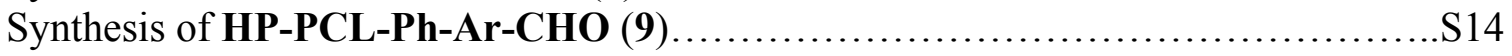

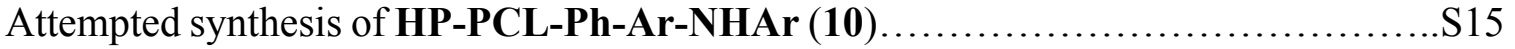

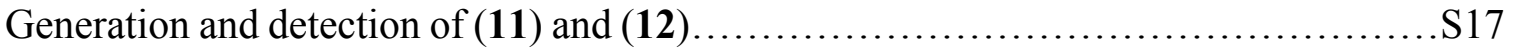

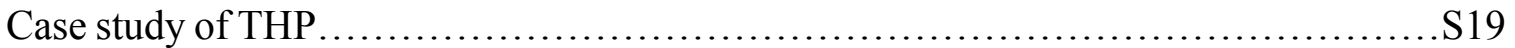

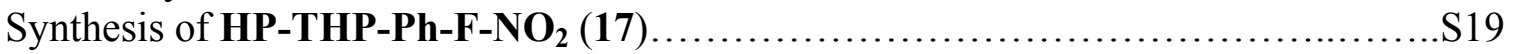

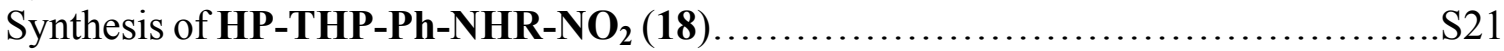

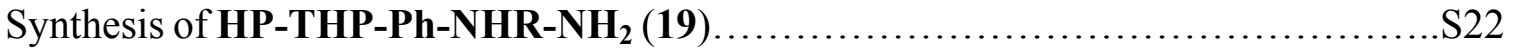

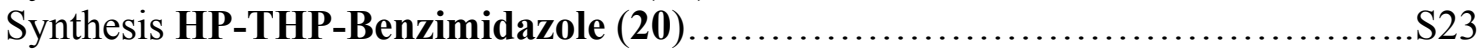

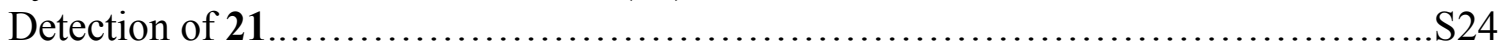

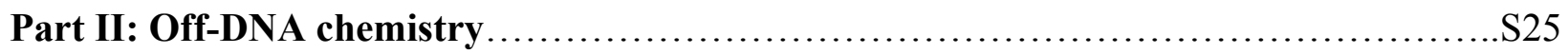

Synthesis of 3-\{[(4-chloro-3-hydroxyphenyl)amino]methyl $\}-5$-(4-chloro-7-quinolinyl)-

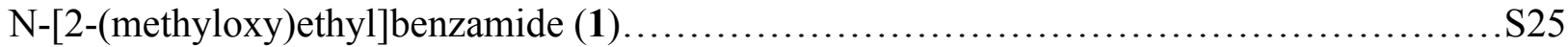

Synthesis of 3-(((4-chloro-3-hydroxyphenyl)amino)methyl)-5-(4-((4-chloro-3-

hydroxyphenyl)amino)quinolin-7-yl)-N-(2-methoxyethyl)benzamide (2)................S34

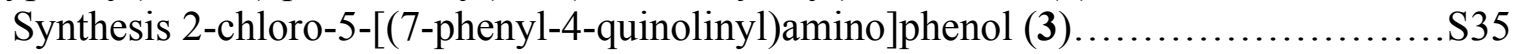

Synthesis of N-(7-phenylquinolin-4-yl)benzo[d]thiazol-5-amine (4)...............S38

Synthesis of 9H-fluoren-9-yl)methyl (2-((6-(azidomethyl)tetrahydro-2H-pyran-2-

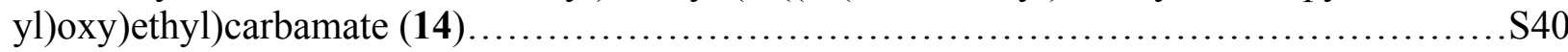




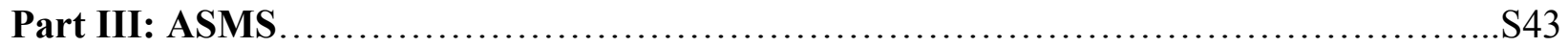

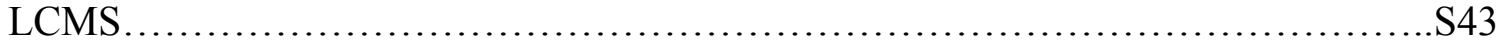

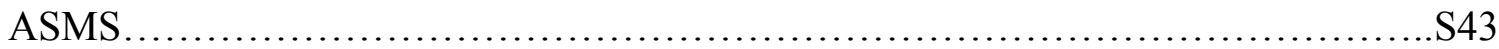

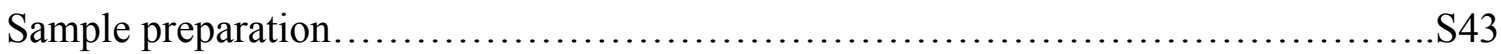

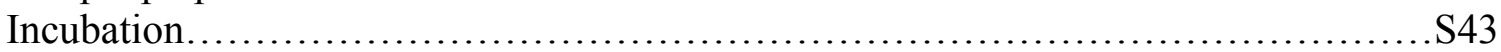

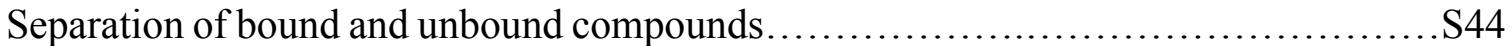

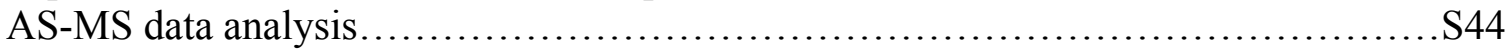

\section{Figures}

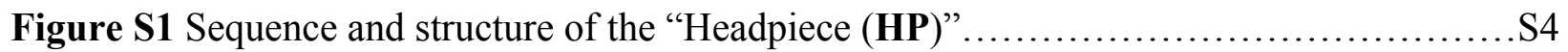

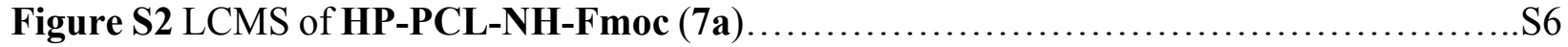

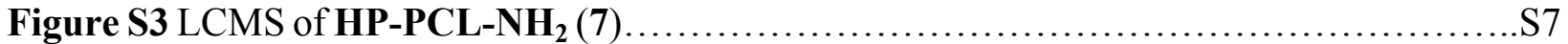

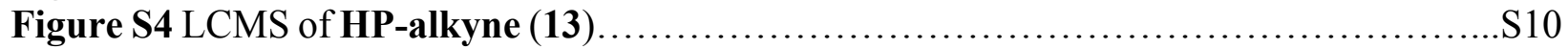

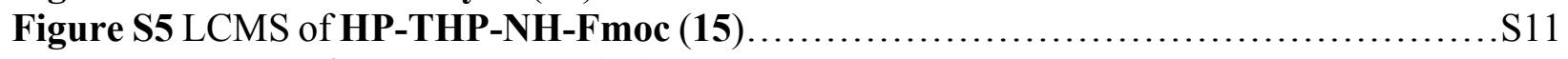

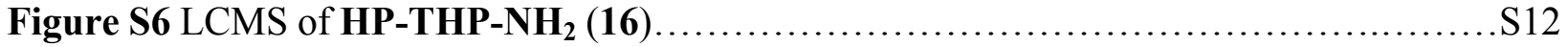

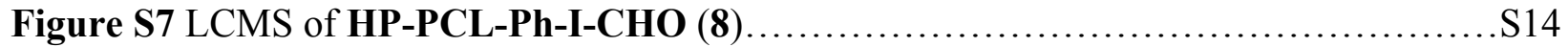

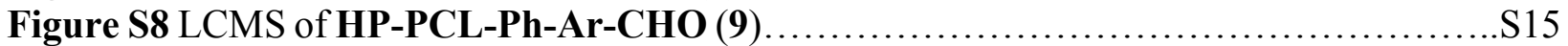

Figure S9 LCMS of attempted synthesis of HP-PCL-Ph-Ar-NHAr (10) .................S16

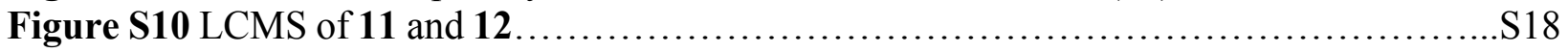

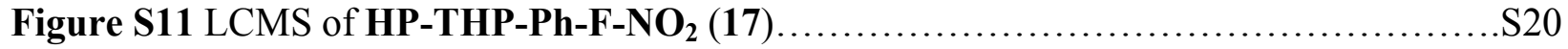

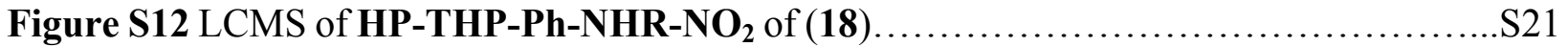

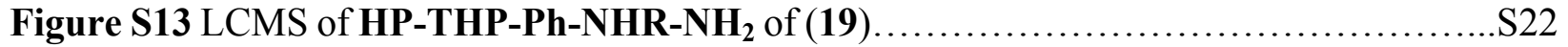

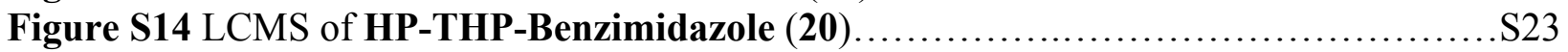

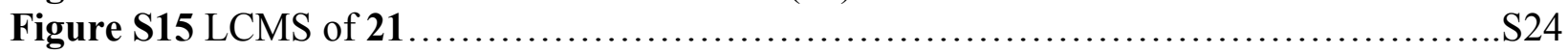

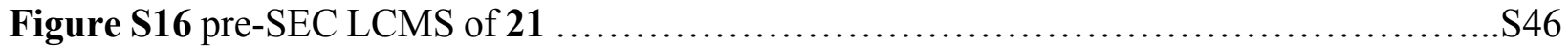

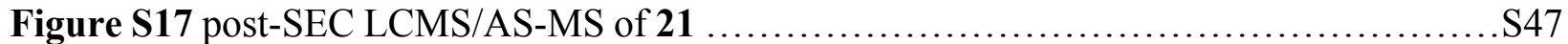

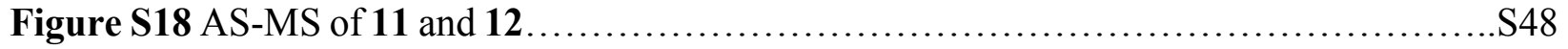

\section{Schemes}

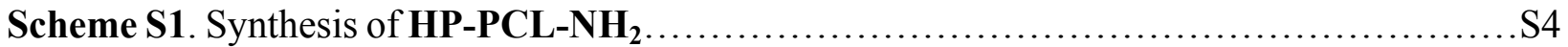

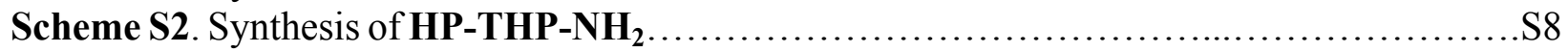

Scheme S3 Case study of Photocleavable Linker (PCL) .................................S13

Scheme S4 Case study of THP.......................................................... 


\section{Part I: On-DNA chemistry}

\section{Analytical Methods}

On-DNA reactions conducted were analyzed by LCMS. Samples (ca. 100 pmol) were

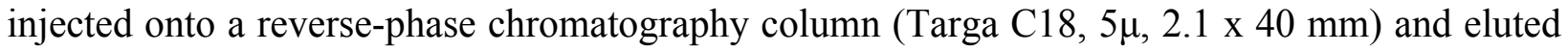
(15-70\% solvent B over $7 \mathrm{~min}, 0.36 \mathrm{~mL} / \mathrm{min}$ flow rate; Solvent A: $0.75 \%$ hexafluoroisopropanol

/ $0.38 \%$ triethylammonium acetate $/ 10 \mu \mathrm{M}$ EDTA in deionized water; Solvent B: $0.75 \%$ HFIP/0.38\% TEAA/10 $\mu \mathrm{M}$ EDTA in 90/10 methanol/water) with monitoring at $260 \mathrm{~nm}$. Effluent was analyzed on a ThermoFinnigan Advantage electrospray mass spectrometer or microtof mass spectrometer in negative ion mode. When necessary, mass deconvolution was achieved using Bruker Compass DataAnalysis 4.4.

\section{Materials}

All solvents and reagents, unless otherwise described, were purchased through vendors and used as supplied. DNA headpiece (HP) was obtained from Biosearch Technologies, Novato, CA. “Headpiece (HP).” Sequence: 5'-/5Phos/GAGTCA/iSp9/iUniAmM/iSp9/TGACTCCC-3'

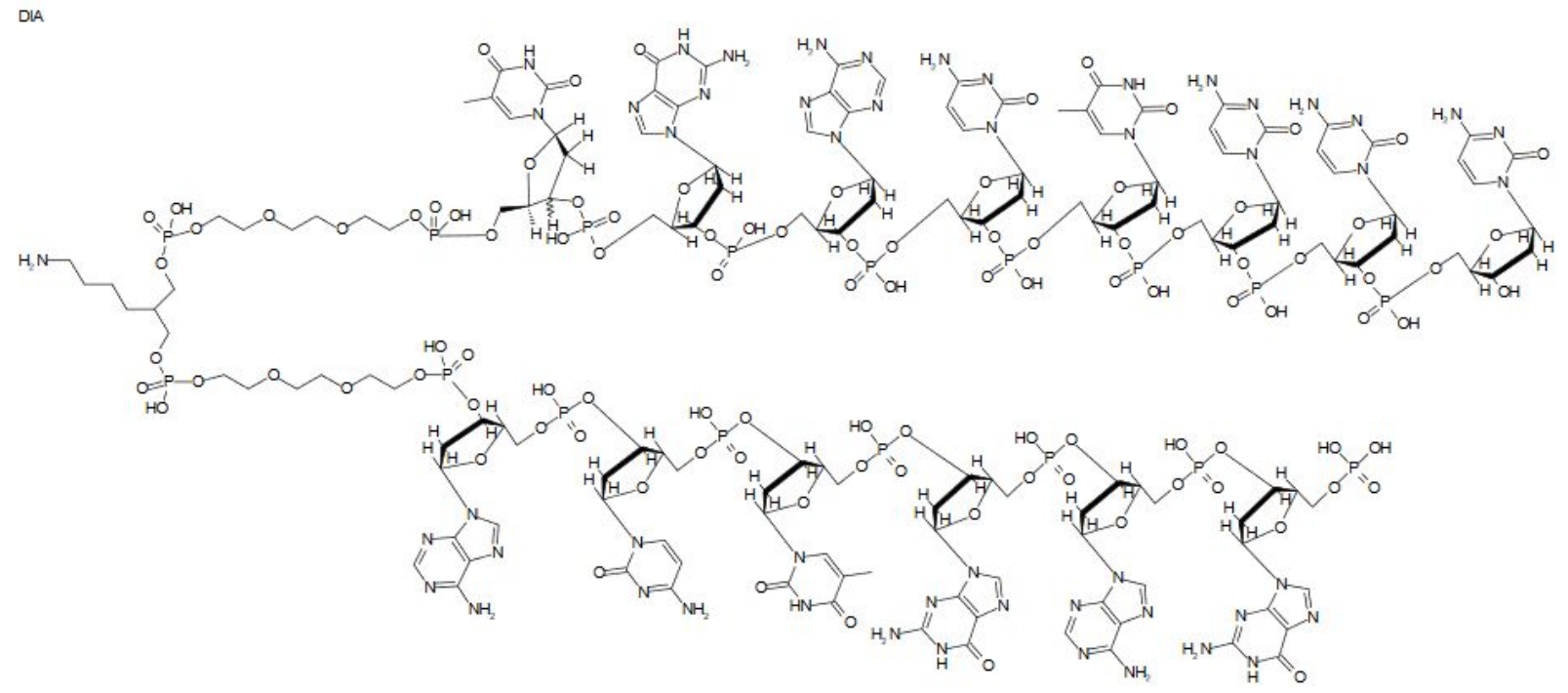




\section{$2 \mathrm{NH}_{2}, \mathrm{HP}^{-\mathrm{NH}_{2}}(5)$}

Figure S1. Sequence and structure of the "Headpiece (HP)". MW $=4937$ D

\section{General procedure for ethanol precipitation}

To the reaction mixture containing DNA, one-tenth volume of $\mathrm{NaCl}(5 \mathrm{M})$ was added, followed by the addition of 2.5 volumes of cold $100 \%$ ethanol. The mixture was left at $-80{ }^{\circ} \mathrm{C}$ for $1 \mathrm{~h}$ and then centrifuged for $20 \mathrm{~min}$ at $4{ }^{\circ} \mathrm{C}$ in a microcentrifuge at $13000 \mathrm{rpm}$. The supernatant was then removed and the DNA pellet was afforded as a white solid after freeze-drying.

\section{Synthesis of HP-PCL-NH}

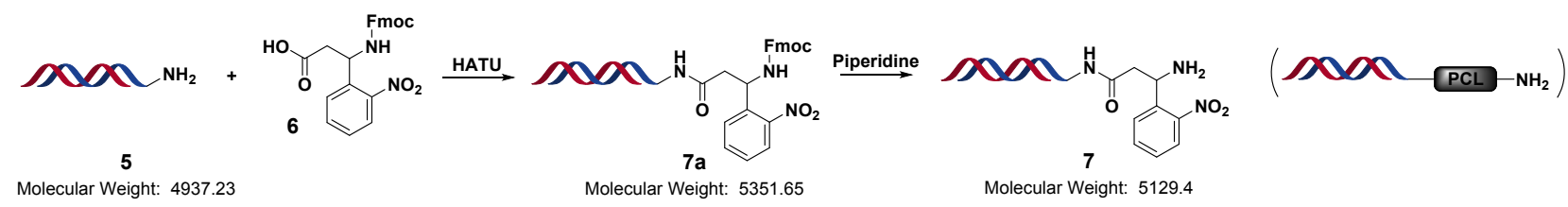

Scheme S1. Synthesis of HP-PCL-NH

In a plastic tube, 40 equiv. of 3-(9-Fluorenylmethyloxycarbonyl)amino-3-(2nitrophenyl)propionic acid (6, FMOC-ANP-OH, Innovochem, CAS \# 171778-06-6, $200 \mu \mathrm{mol}$ in $1 \mathrm{~mL}$ of DMF) was mixed with 40 equiv. of $\mathrm{N}, \mathrm{N}$-diisopropylethylamine $(200 \mu \mathrm{mol}$ in $1 \mathrm{~mL}$ of DMF), followed by 40 equiv. of HATU (1-[bis(dimethyl-amino)methylene]-1H-1,2,3triazolo[4,5-b]pyridinium 3-oxidehexafluorophosphate, $200 \mu \mathrm{mol}$ in $1 \mathrm{~mL}$ of DMF). The resulting mixture was quickly transferred into a solution of DNA headpiece $(\mathbf{H P})(\mathbf{5}, 5 \mu \mathrm{mol}$ in $5 \mathrm{~mL}$ of 250 $\mathrm{mM} \mathrm{pH} 9.4$ sodium borate buffer) and vortexed. The reaction proceeded at room temperature for 30 min and was monitored by LCMS (estimated LCMS conversion $>90 \%$ ). Upon completion, the 
reaction was subjected for ethanol precipitation and then reconstituted in water at $1 \mathrm{mM}$ of HPPCL-NH-Fmoc (7a). To this oligo solution was added $10 \%$ by volume of neat piperidine. The reaction was allowed to proceed at room temperature and monitored by LCMS (estimated LCMS conversion $>95 \%$ ). Once the reaction was complete, the "EtOH Precipitation Protocol" was followed, and then reconstituted in water at $2 \mathrm{mM}$ of $\mathbf{H P - P C L - N \mathbf { N } _ { 2 }}$ (7) for further steps. Purity of the final product crude mixture was determined by LCMS total ion count.

\section{General procedure for photocleavage}

The oligo $0.25 \mathrm{mM}$ solution in 4:1 (water:MeOH) was transferred to one well of a flat-bottomed, 24-well microtiter plate (Corning ${ }^{\circledR}$ Costar ${ }^{\circledR}$ clear polystyrene flat bottom, CLS3738). The reaction mixture was irradiated with $365 \mathrm{~nm}$ light at $4{ }^{\circ} \mathrm{C}$ for $1 \mathrm{~h}$ (light source should be positioned directly above transparent plate, $\sim 2 \mathrm{~cm}$, UVP 95-0192-01 Model UVLS-225D Mineralight UV Display Lamp, 254/365nm Wavelength, $115 \mathrm{~V}$ was used for photocleavage). Once the reaction was deemed complete, the "EtOH Precipitation Protocol" was followed. 

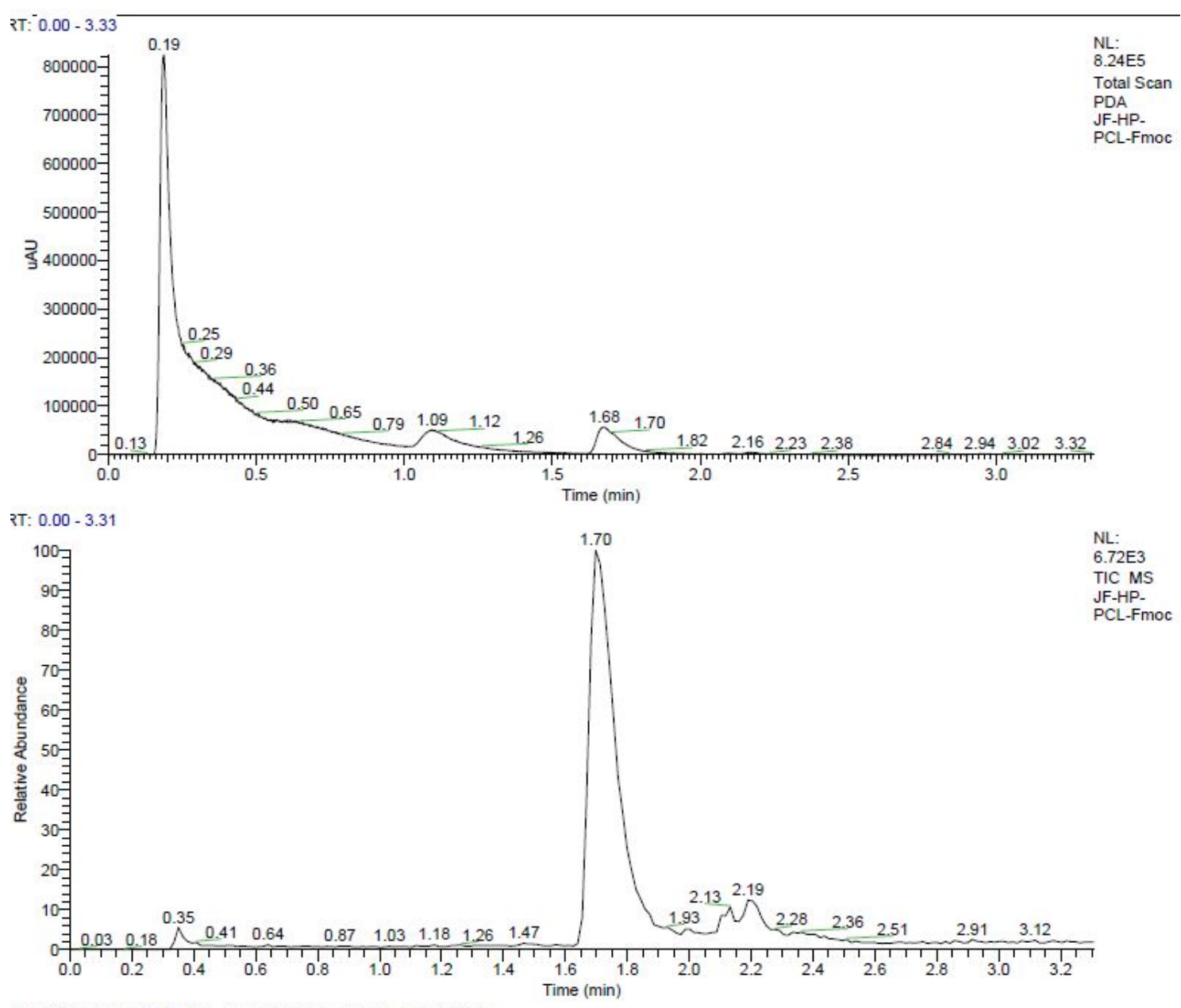

IF-HP-PCL-Fmoc \#117-128 RT: $1.68-1.84$ AV: 12 NL: 1.30 E 3

r: ITMS - c ESI Full ms [600.00-2000.00]

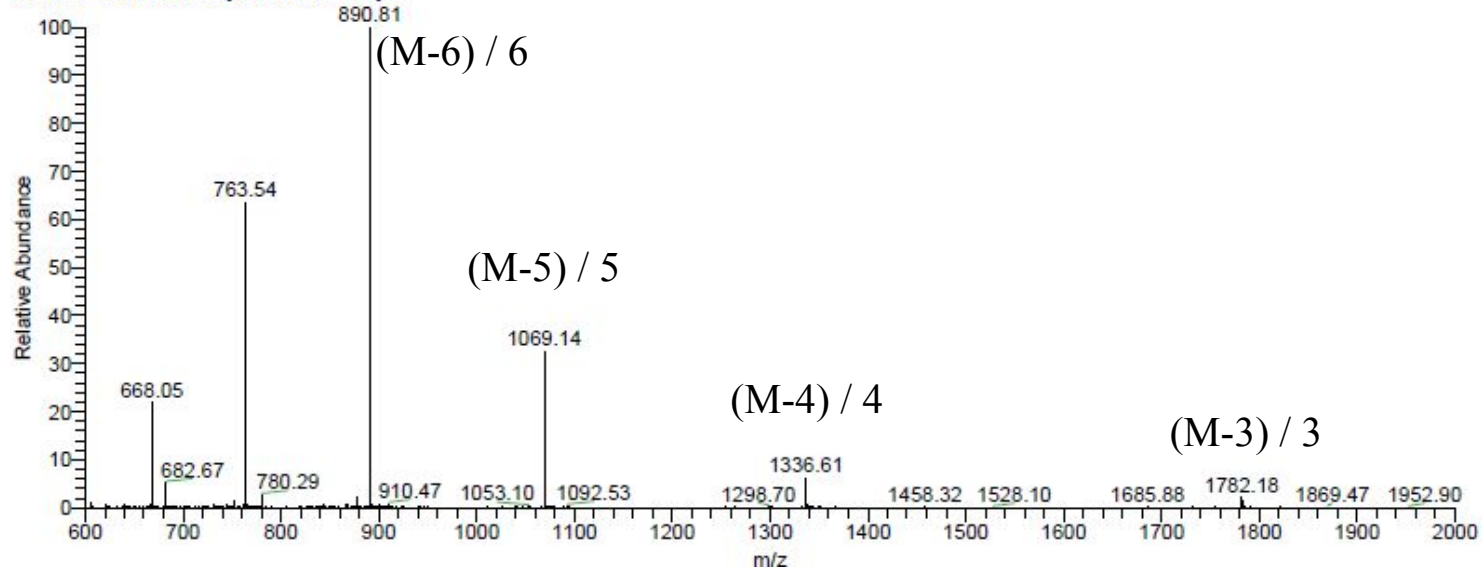

Figure S2. LCMS of HP-PCL-NH-Fmoc (7a), MW 5351.65, $\mathrm{C}_{178} \mathrm{H}_{233} \mathrm{~N}_{54} \mathrm{O}_{106} \mathrm{P}_{17}$. 

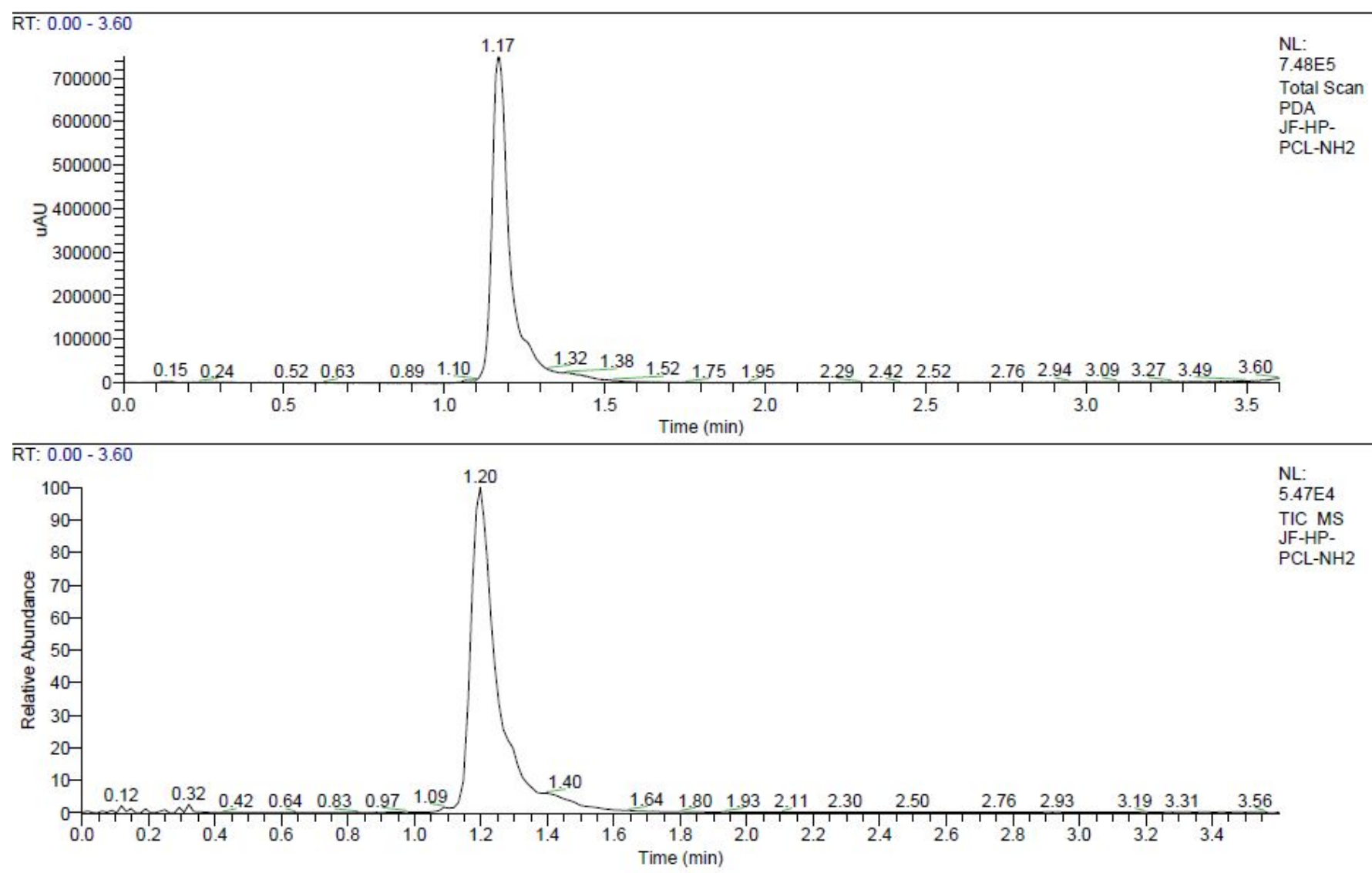

JF-HP-PCL-NH2 \#80-95 RT: 1.15-1.34 AV: $16 \quad$ NL: $8.78 E 3$

T: ITMS - c ESI Full ms [600.00-2000.00]

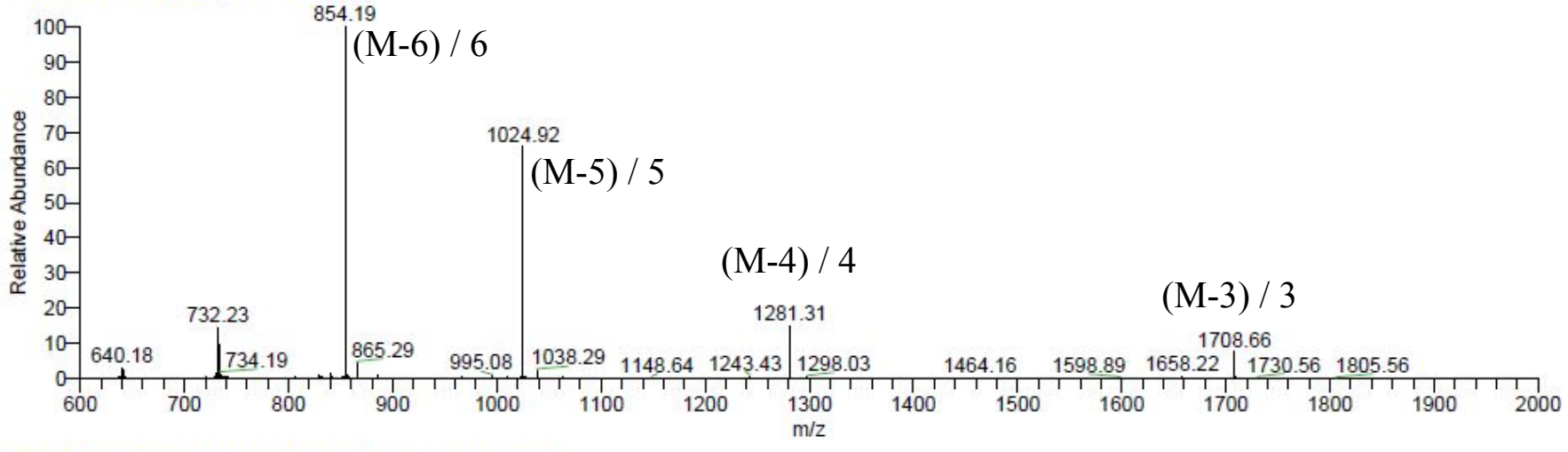

JF-HP-PCL-NH2 \#91-93 RT: 1.28-1.31 AV: 3 NL: 2.34E3

Figure S3. LCMS of HP-PCL- $\mathbf{N H}_{2}$ (7), MW 5129.40, $\mathrm{C}_{163} \mathrm{H}_{223} \mathrm{~N}_{54} \mathrm{O}_{104} \mathrm{P}_{17}$. 


\section{Synthesis of HP-THP-NH}

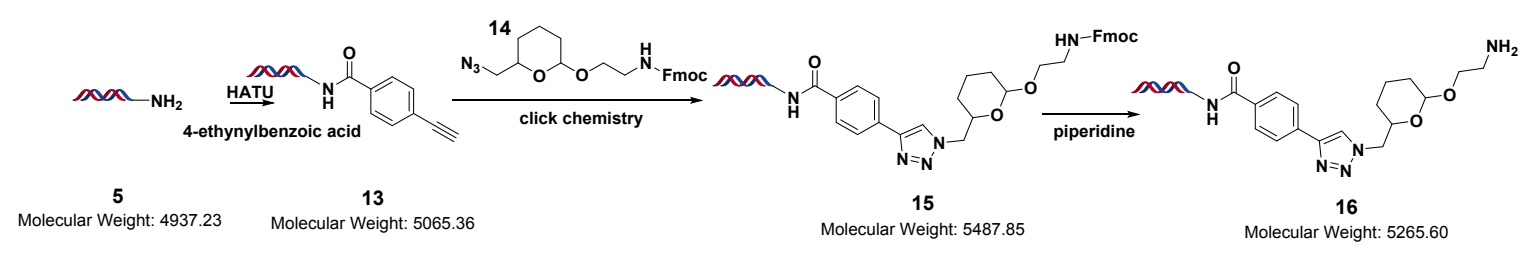

Scheme S2. Synthesis of HP-THP-NH2

In a plastic tube, 40 equiv. of 4-ethynylbenzoic acid (ASTA Tech CAS\# 10602-00-3, 200 $\mu \mathrm{mol}$ in $1 \mathrm{~mL}$ of DMF) was mixed with 40 equiv. of $\mathrm{N}, \mathrm{N}$-diisopropylethylamine $(200 \mu \mathrm{mol}$ in $1 \mathrm{~mL}$ of DMF), followed by 40 equiv. of HATU (1-[bis(dimethyl-amino)methylene]-1H-1,2,3triazolo[4,5-b]pyridinium 3-oxidehexafluorophosphate, $200 \mu \mathrm{mol}$ in $1 \mathrm{~mL}$ of DMF). The resulting mixture was quickly transferred into a solution of DNA headpiece $(5,5 \mu \mathrm{mol}$ in $5 \mathrm{~mL}$ of $250 \mathrm{mM}$ pH 9.4 sodium borate buffer) and vortexed. The reaction proceeded at room temperature for 30 min and was monitored by LCMS (estimated LCMS conversion $>90 \%$ ). Upon completion, the reaction was subjected for EtOH precipitation and then reconstituted in water at $2 \mathrm{mM}$.

To the $1 \mathrm{mM}$ HP-alkyne (13) $(5000 \mu \mathrm{L}, 5 \mu \mathrm{mol})$ in $250 \mathrm{mM} \mathrm{pH} 9.4$ sodium borate buffer, was added 20 equiv. of 200 mM DMA solution of 14*, (9H-fluoren-9-yl)methyl (2-((6(azidomethyl)tetrahydro-2H-pyran-2-yl)oxy)ethyl)carbamate (custom synthesized by GVK Bio, $500 \mu \mathrm{L}, 100 \mu \mathrm{mol})$, then added 10 equiv. of $200 \mathrm{mM}$ water solution of copper(II) sulfate pentahydrate $(250 \mu \mathrm{L}, 50.0 \mu \mathrm{mol})$, followed by 15 equiv. $200 \mathrm{mM}$ water solution of sodium ascorbate (sodium (R)-2-((S)-1,2-dihydroxyethyl)-4-hydroxy-5-oxo-2,5-dihydrofuran-3-olate) $(375 \mu \mathrm{L}, 75 \mu \mathrm{mol})$ and vortexed. The reaction proceeded at room temperature overnight. $1250 \mu \mathrm{L}$ DMA was then added to facilitate solubility, and the reaction was monitored by LCMS $(1 \mu \mathrm{L}$ aliquot of reaction mixture was added to a small Eppendorf tube, followed by $1 \mu \mathrm{L}$ of $100 \mathrm{mM}$ sodium diethyldithiocarbamate, mixed well, then added $50 \mathrm{uL}$ water, centrifuged using $30 \mu \mathrm{L}$ clear 
solution for LCMS) (estimated LCMS conversion $>90 \%$ ). Upon completion, the reaction was subjected to ethanol precipitation and then HP-THP-NH-Fmoc (15) was reconstituted in water at $2 \mathrm{mM}$. To this oligo solution was added $10 \%$ by volume of neat piperidine. The reaction was allowed to proceed at room temperature and monitored by LCMS (estimated LCMS conversion $>95 \%$ ). Once the reaction was complete, the "EtOH Precipitation Protocol" was followed, and then reconstituted in water at $2 \mathrm{mM}$ of HP-THP- $\mathbf{N H}_{2}$ (16) for further steps. Purity of the final crude product mixture was determined by LCMS total ion count.

*See part II, off-DNA chemistry, for synthesis of 14.

\section{General procedure for THP cleavage}

The oligo $0.25 \mathrm{mM}$ in $0.1 \%$ formic acid water solution was allowed to proceed at $60{ }^{\circ} \mathrm{C}$ for $1 \mathrm{~h}$. Once the reaction was complete, the "EtOH Precipitation Protocol" was followed. For small scale reactions, the plate was directly evaporated under a gentle stream of nitrogen, and the dried pellet was submitted for testing by ASMS. 


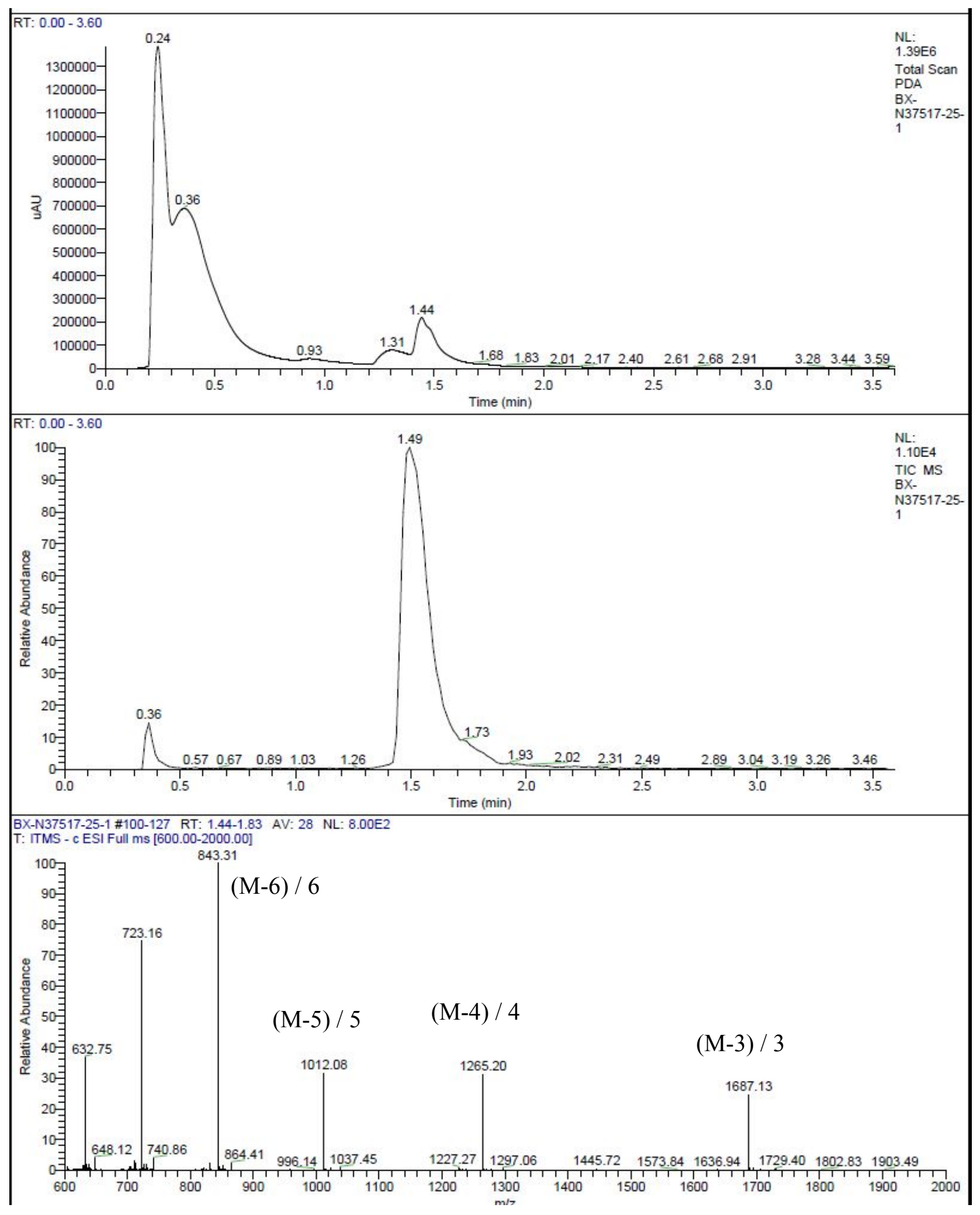

Figure S4. LCMS of HP-alkyne (13), MW 5065.36, $\mathrm{C}_{163} \mathrm{H}_{219} \mathrm{~N}_{52} \mathrm{O}_{102} \mathrm{P}_{17}$. 

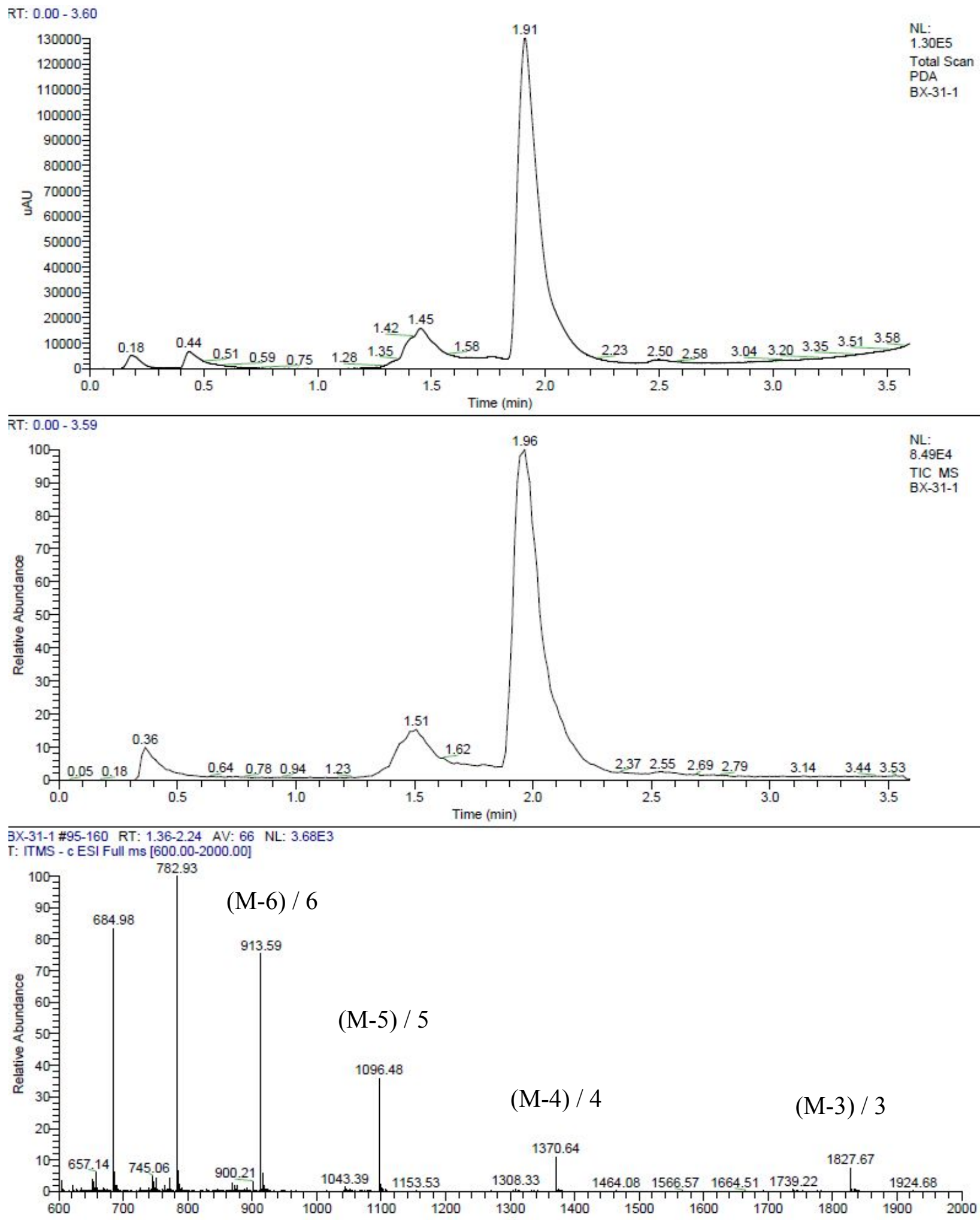

Figure S5. LCMS of HP-THP-NH-Fmoc (15), MW 5487.85, $\mathrm{C}_{186} \mathrm{H}_{245} \mathrm{~N}_{56} \mathrm{O}_{106} \mathrm{P}_{17}$. 


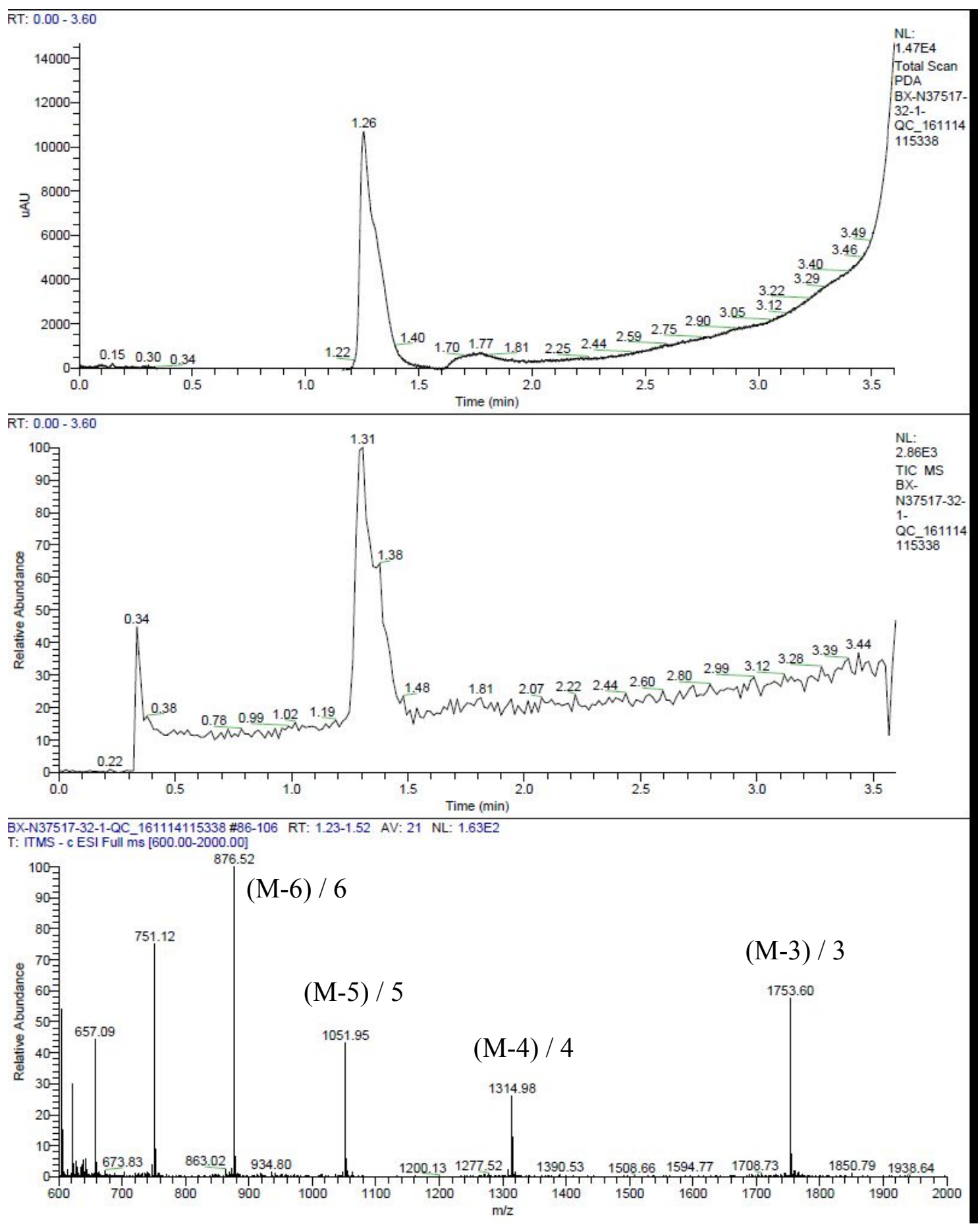

Figure S6. LCMS of HP-THP-NH $\mathbf{N H}_{2}$ (16), MW 5265.6, $\mathrm{C}_{171} \mathrm{H}_{235} \mathrm{~N}_{56} \mathrm{O}_{104} \mathrm{P}_{17}$. 


\section{Case study of Photocleavable Linker (PCL)}

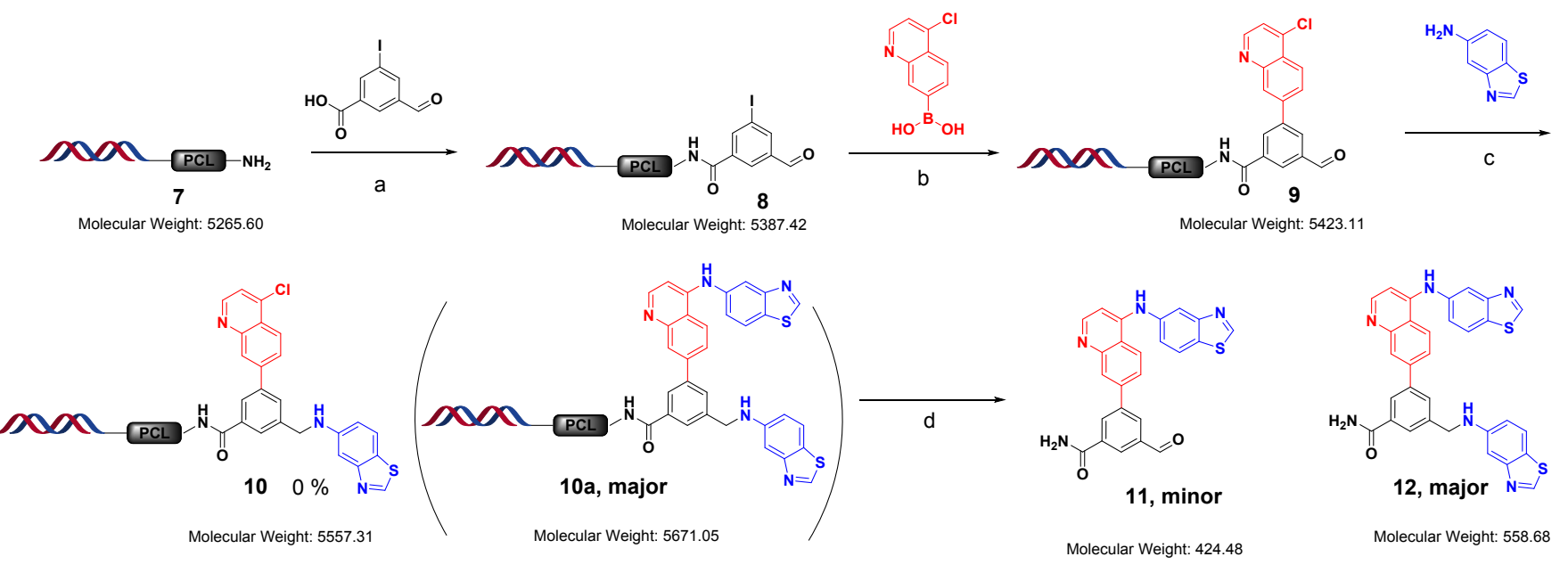

Scheme S3. Case study of Photocleavable Linker (PCL)

\section{Synthesis of HP-PCL-Ph-I-CHO (8)}

In a $2 \mathrm{~mL}$ plastic tube, 80 equiv. of 3-formyl-5-iodobenzoic acid $(12 \mu \mathrm{mol}$ in $60 \mu \mathrm{L}$ of

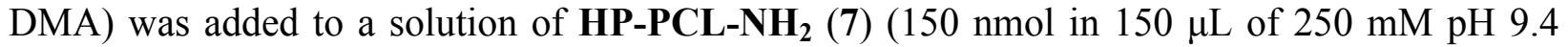
sodium borate buffer), followed by 80 equiv. of freshly prepared DMTMM water solution (12 $\mu \mathrm{mol}$ in $60 \mu \mathrm{L}$ ) and vortexed. The reaction proceeded at room temperature and was monitored by LCMS (estimated LCMS conversion $>80 \%$ ). Once the reaction was complete, the "EtOH Precipitation Protocol" was followed, and then reconstituted in water at $2 \mathrm{mM}$ of HP-PCL-Ph-ICHO (8) for the next step. 

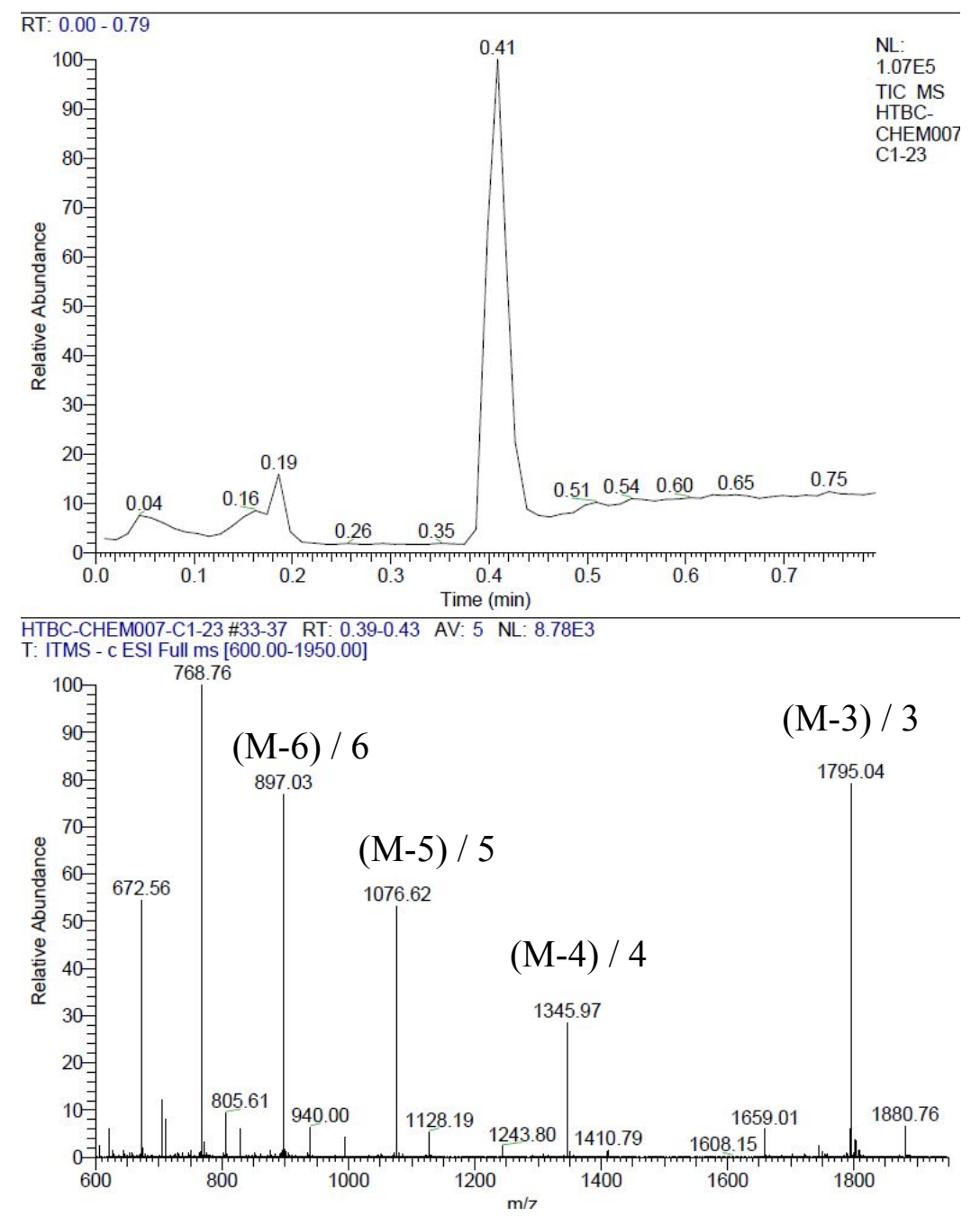

Figure S7. LCMS of HP-PCL-Ph-I-CHO (8), MW 5387.42, $\mathrm{C}_{171} \mathrm{H}_{226} \mathrm{IN}_{54} \mathrm{O}_{106} \mathrm{P}_{17}$.

\section{Synthesis of HP-PCL-Ph-Ar-CHO (9)}

In a $2 \mathrm{~mL}$ plastic tube, 40 equiv. of (4-chloroquinolin-7-yl)boronic acid (6 $\mu \mathrm{mol}$ in $10 \mu \mathrm{L}$ of DMA) and 80 equiv. of $\mathrm{Na}_{2} \mathrm{CO}_{3}(12 \mu \mathrm{mol}$ in $20 \mu \mathrm{L}$ of DMA $)$ were added to a solution of HPPCL-Ph-I-CHO (8) (150 nmol in $150 \mu \mathrm{L}$ of water), followed by 0.5 equiv. of degassed $\mathrm{Pd}\left(\mathrm{PPh}_{3}\right)_{4}$ (75 nmol in $25 \mu \mathrm{L}$ of acetonitrile) and vortexed. The reaction was allowed to proceed at $80{ }^{\circ} \mathrm{C}$ for $5 \mathrm{~h}$, and was monitored by LCMS (estimated LCMS conversion $>70 \%$ ). Once the reaction was deemed complete, the reaction mixture was centrifuged and then the supernatant was carefully removed from the Pd-containing precipitate using a pipette. The "EtOH Precipitation Protocol" 
was followed and the product reconstituted in water at $2 \mathrm{mM}$ of HP-PCL-Ph-Ar-CHO (9) for the next step.
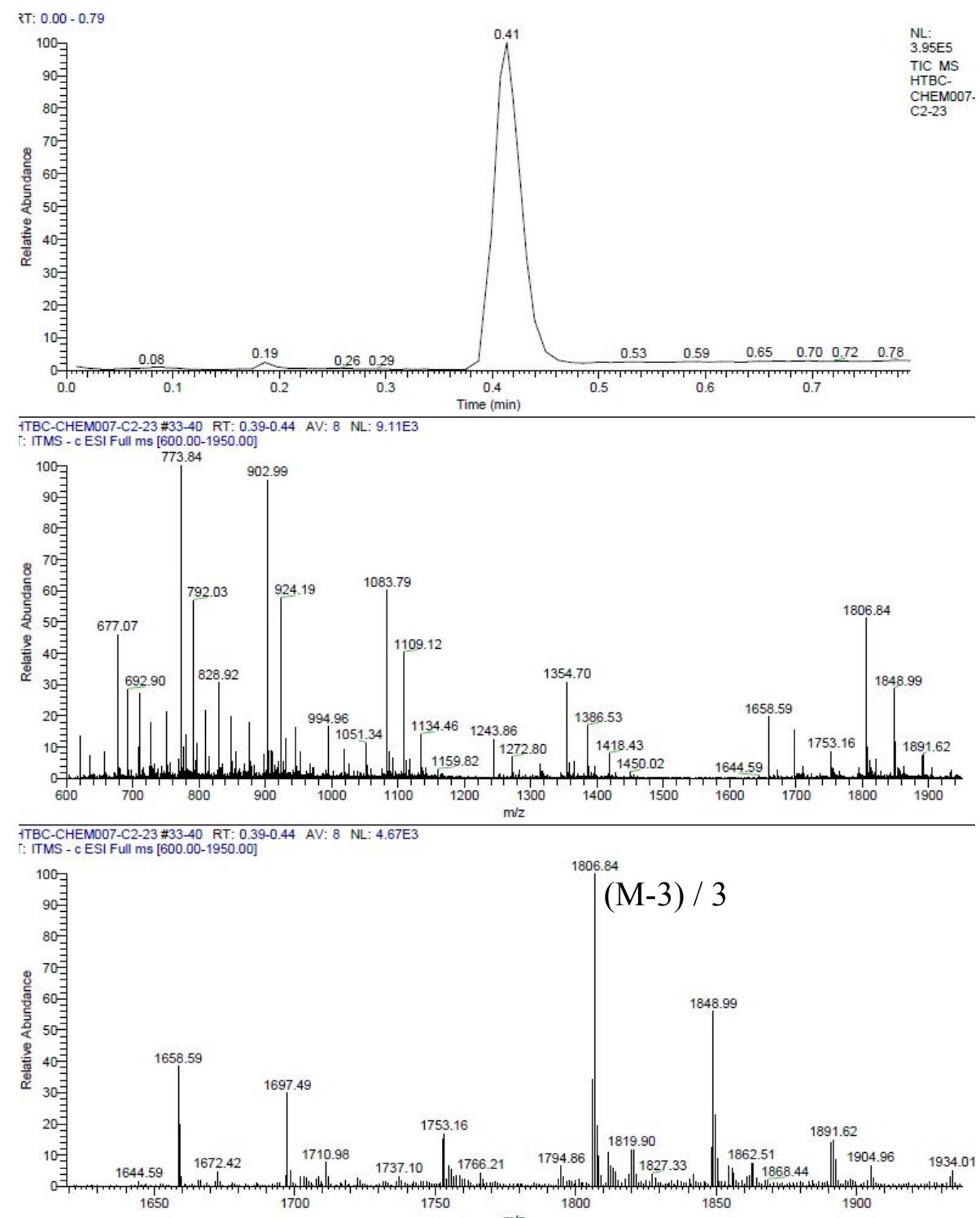

Figure S8. LCMS of HP-PCL-Ph-Ar-CHO (9), MW 5423.11, $\mathrm{C}_{180} \mathrm{H}_{231} \mathrm{ClN}_{55} \mathrm{O}_{106} \mathrm{P}_{17}$.

\section{Attempted synthesis of HP-PCL-Ph-Ar-NHAr (10)}

In a $2 \mathrm{~mL}$ plastic tube, 80 equiv. of benzo[d]thiazol-5-amine $(12 \mu \mathrm{mol}$ in $60 \mu \mathrm{L}$ of DMA) was added into a solution of HP-PCL-Ph-Ar-CHO (9) $(150 \mathrm{nmol}$ in $150 \mu \mathrm{L}$ of $250 \mathrm{mM}$ pH 5.5 sodium phosphate buffer), followed by 80 equiv. of freshly prepared sodium cyanoborohydride $\left(\mathrm{NaCNBH}_{3}\right)$ water solution $(12 \mu \mathrm{mol}$ in $30 \mu \mathrm{L})$ and vortexed. The reaction was allowed to proceed 
at $60{ }^{\circ} \mathrm{C}$ for $16 \mathrm{~h}$ and was monitored by LCMS (estimated LCMS conversion $>60 \%$, 10a). Once the reaction was complete, the "EtOH Precipitation Protocol" was followed and then reconstituted in water at $2 \mathrm{mM}$ for the next step.
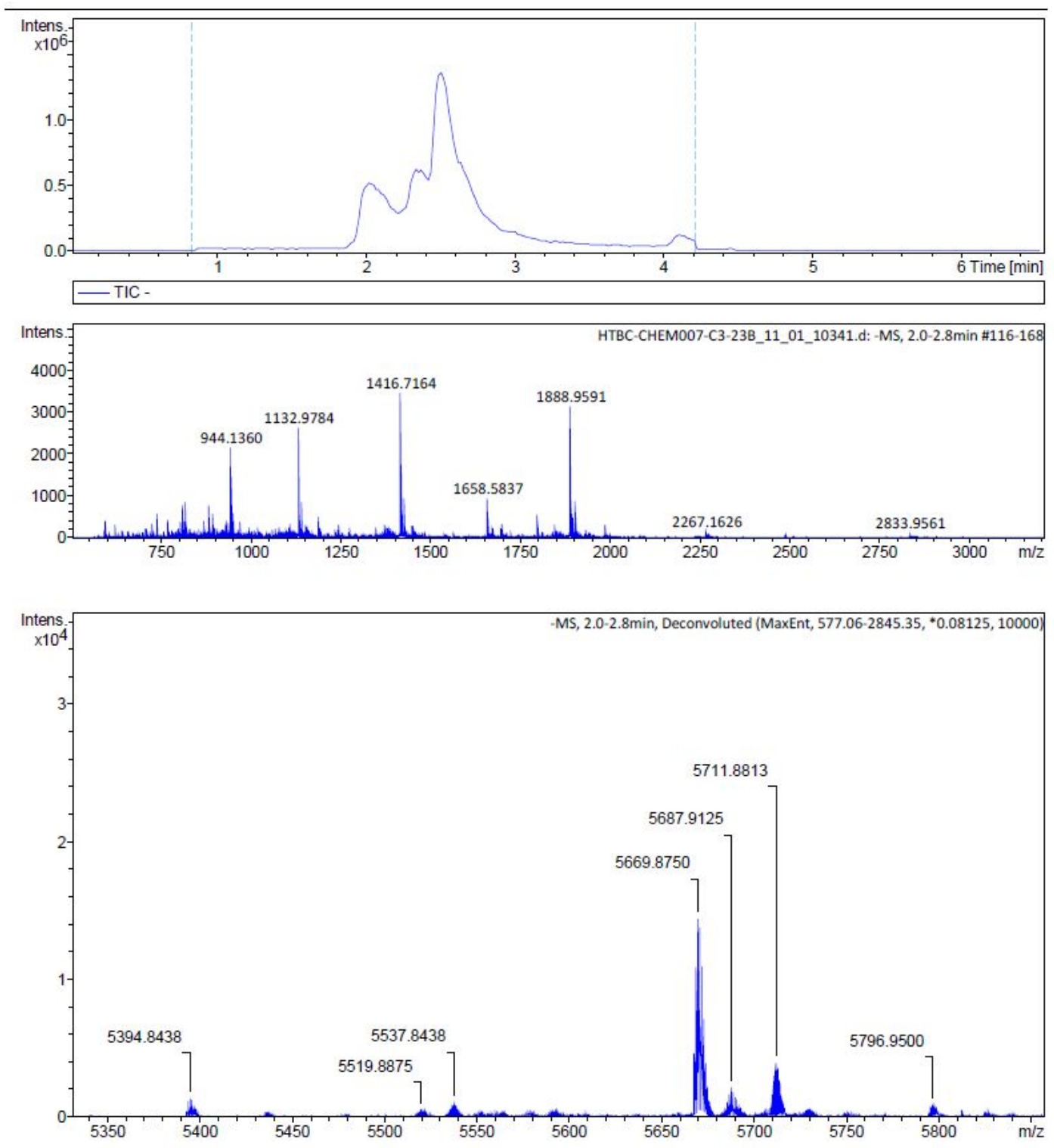

Figure S9. LCMS of attempted synthesis of HP-PCL-Ph-Ar-NHAr (10), MW 5557.31, $\mathrm{C}_{187} \mathrm{H}_{237} \mathrm{ClN}_{57} \mathrm{O}_{105} \mathrm{P}_{17} \mathrm{~S}$; 10a, MW 5671.05, $\mathrm{C}_{194} \mathrm{H}_{242} \mathrm{~N}_{59} \mathrm{O}_{105} \mathrm{P}_{17} \mathrm{~S}_{2}$. 
Generation and detection of (11) and (12)

The "General procedure for PCL cleavage" described above was followed for the generation of $\mathbf{1 1}$ and 12, also see the part III AS-MS. Compound 11 LCMS $(m / z):[\mathrm{M}+\mathrm{H}]^{+}$calc'd for $\mathrm{C}_{31} \mathrm{H}_{22} \mathrm{~N}_{6} \mathrm{OS}_{2}$, 559.13; found, 559.21. Compound 12 LCMS $(m / z)$ : $[\mathrm{M}+\mathrm{H}]^{+}$calc'd for $\mathrm{C}_{24} \mathrm{H}_{16} \mathrm{~N}_{4} \mathrm{O}_{2} \mathrm{~S}$, 425.10; found 425.23. 


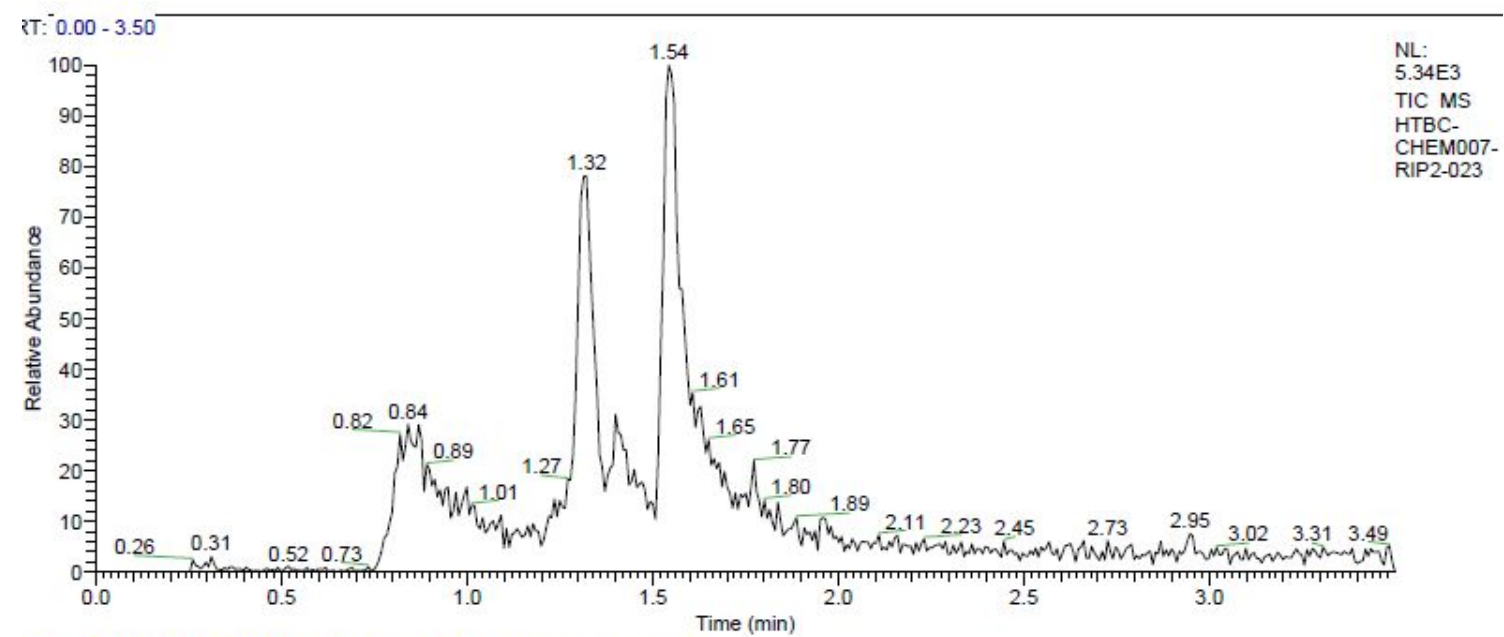

ITBC-CHEM007-RIP2-023 \#182-189 RT: 1.30-1.35 AV: 8 NL: $1.96 E^{3}$

: ITMS + c ESI Full ms [150.00-1600.00]

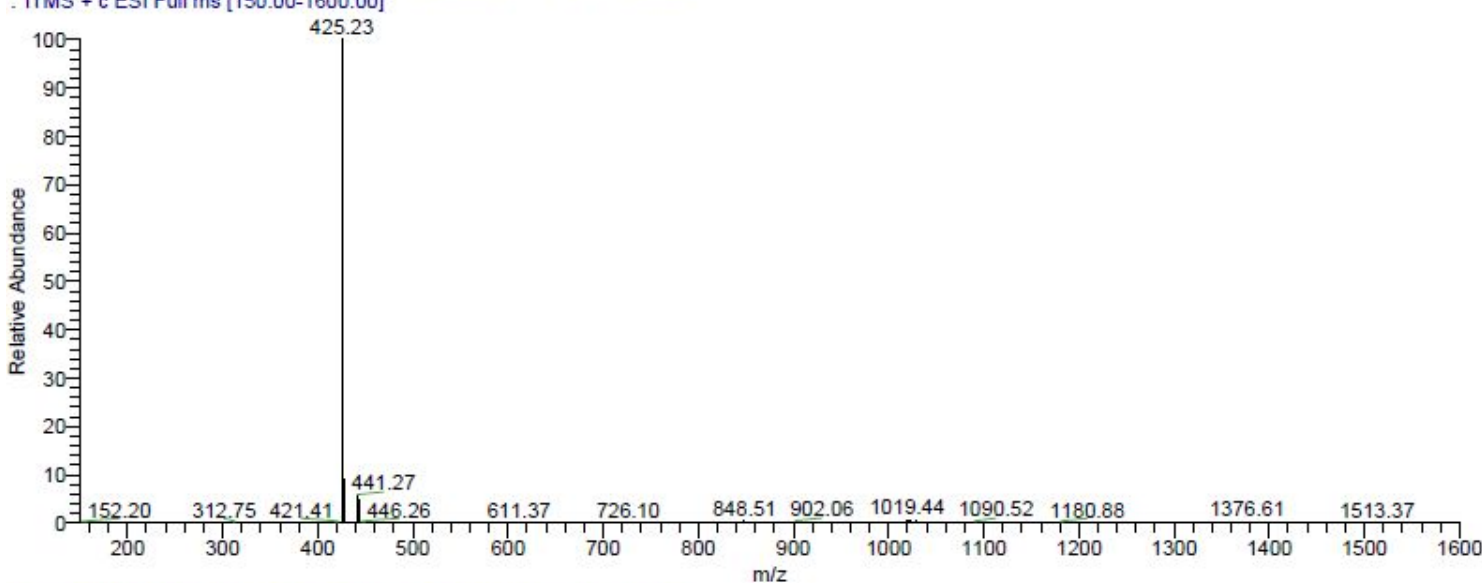

ITBC-CHEM007-RIP2-023 \#215-223 RT: $1.54-1.59$ AV: 9 NL: 1.04 E3

$\because$ ITMS + c ESI Full ms [150.00-1600.00]

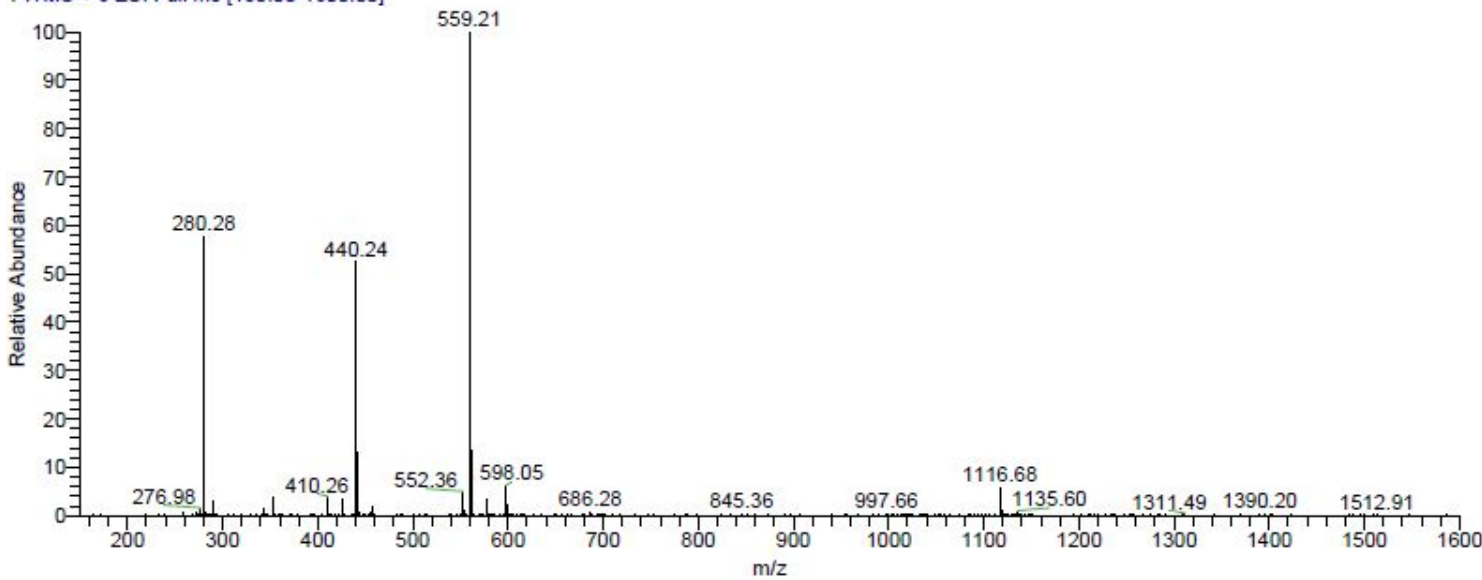

Figure S10. LCMS of $\mathbf{1 1}$ and 12 


\section{Case study of THP}

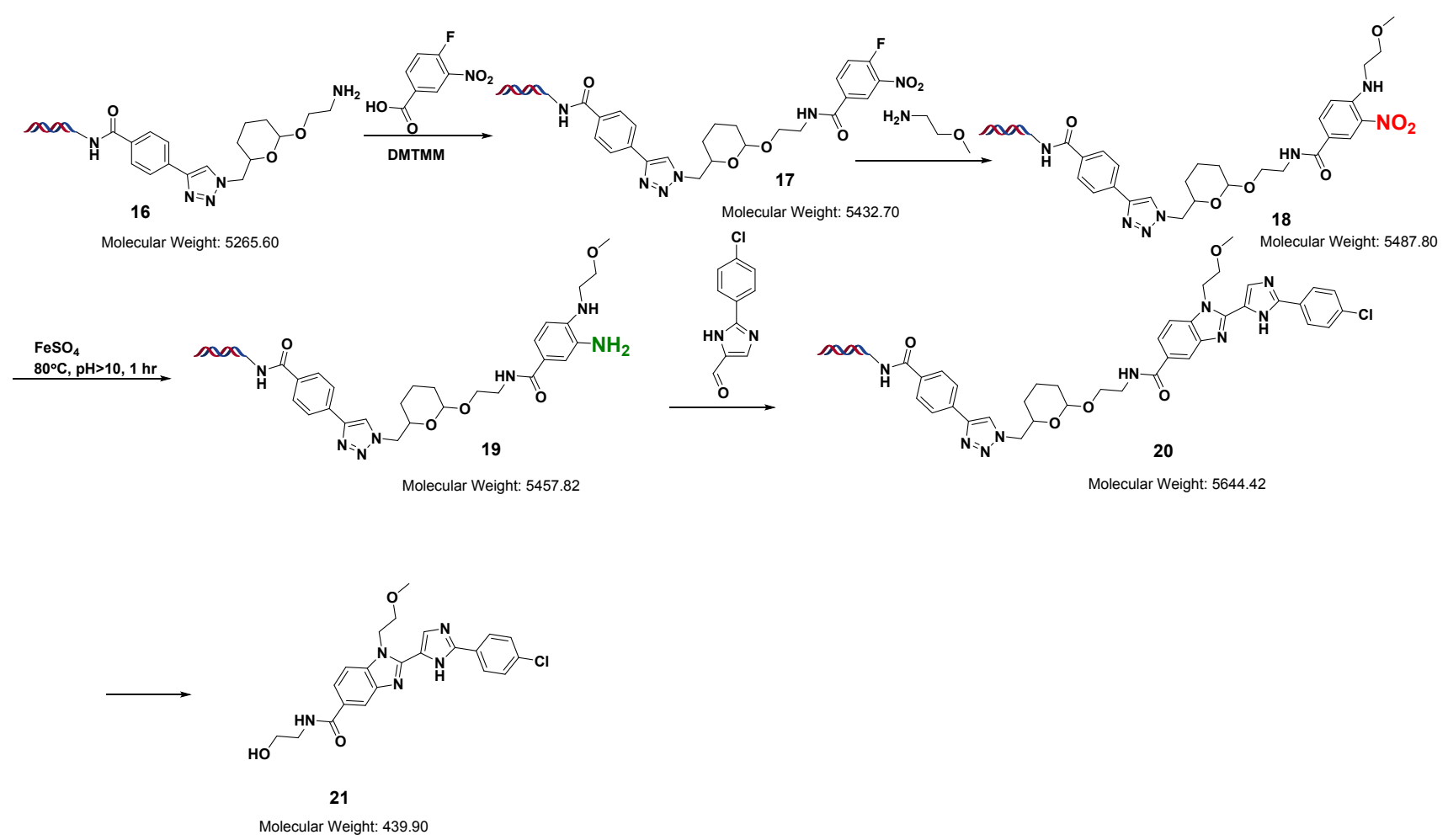

Scheme S4. Case study of THP

\section{Synthesis of HP-THP-Ph-F-NO 2 (17)}

In a $2 \mathrm{~mL}$ plastic tube, 40 equiv. of 4-fluoro-3-nitrobenzoic acid $(100 \mu \mathrm{mol}$ in $0.5 \mathrm{~mL}$ of DMA) was added into a solution of HP-THP-NH $\mathbf{2}$ (16) $(1 \mu \mathrm{mol}$ in $1 \mathrm{~mL}$ of $250 \mathrm{mM} \mathrm{pH} 9.4$ sodium borate buffer), followed by 100 equiv. of freshly prepared DMTMM water solution (100 $\mu$ mol in $0.5 \mathrm{~mL}$ ) and vortexed. The reaction was allowed to proceed at room temperature and was monitored by LCMS(estimated LCMS conversion $>80 \%$ ). Once the reaction was deemed complete, the "EtOH Precipitation Protocol" was followed, and the product was reconstituted in water at $2 \mathrm{mM}$ of HP-THP-NH $\mathbf{2}$ (17) for next step. 

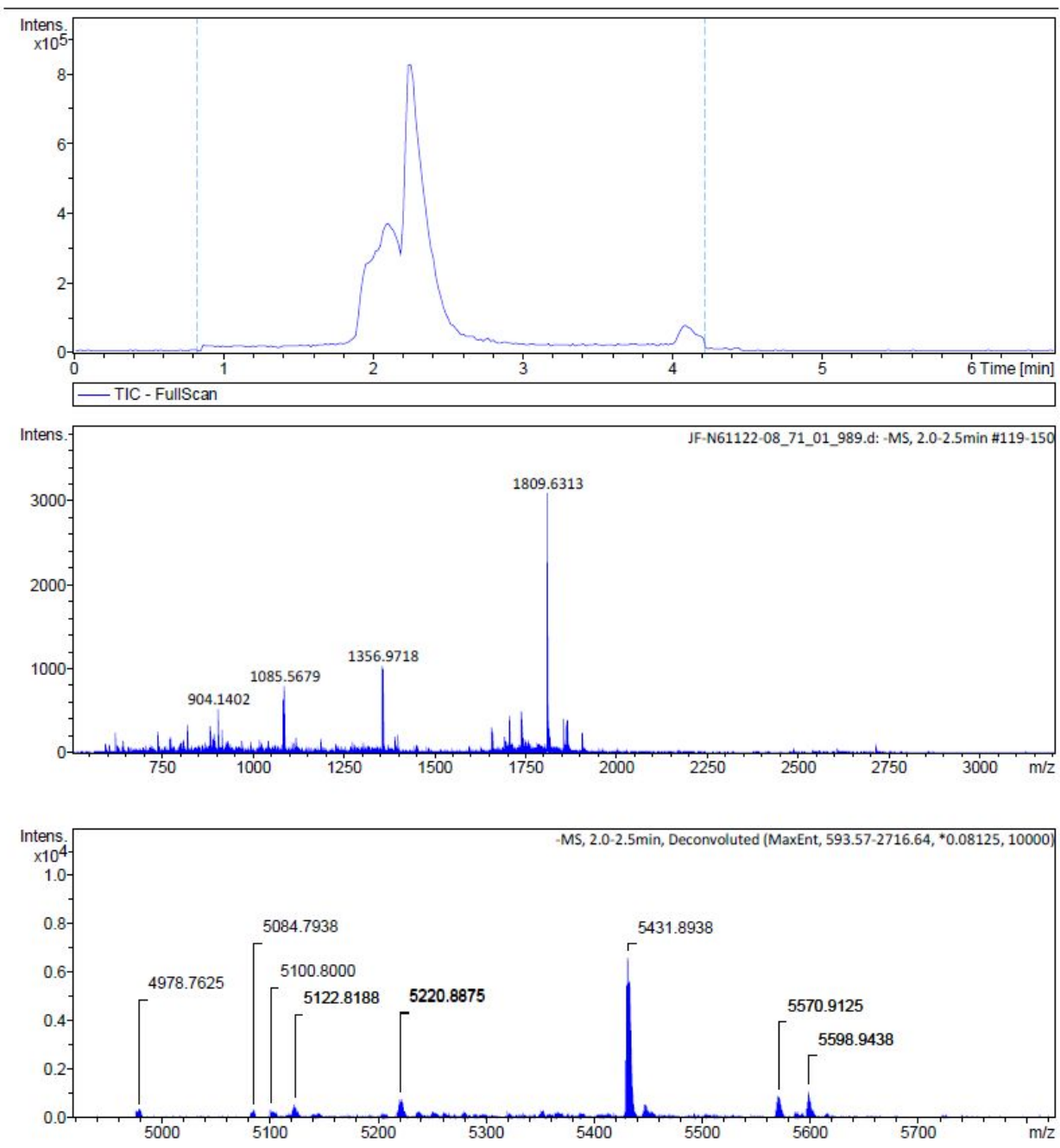

Figure S11. HP-THP-Ph-F-NO2 (17), MW 5432.70, $\mathrm{C}_{178} \mathrm{H}_{237} \mathrm{FN}_{57} \mathrm{O}_{107} \mathrm{P}_{17}$. 


\section{Synthesis of HP-THP-Ph-NHR-NO $2(18)$}

In a $2 \mathrm{~mL}$ plastic tube, 80 equiv. of 2-methoxyethan-1-amine $(24 \mu \mathrm{mol}$ in $120 \mu \mathrm{L}$ of acetonitrile: water=50:50) was added to a solution of $\mathbf{H P - T H P - P h - F - N O}$ (17) (300 nmol in 300 $\mu \mathrm{L}$ of $250 \mathrm{mM} \mathrm{pH} 9.4$ sodium borate buffer) and vortexed. The reaction was allowed to proceed at $60{ }^{\circ} \mathrm{C}$ for $1 \mathrm{~h}$ and was monitored by LCMS (estimated LCMS conversion $>85 \%$ ). Once the reaction was deemed complete, the "EtOH Precipitation Protocol" was followed, and the product reconstituted in water at $2 \mathrm{mM}$ of HP-THP-Ph-NHR-NO $\mathbf{2}$ (18) for the next step.
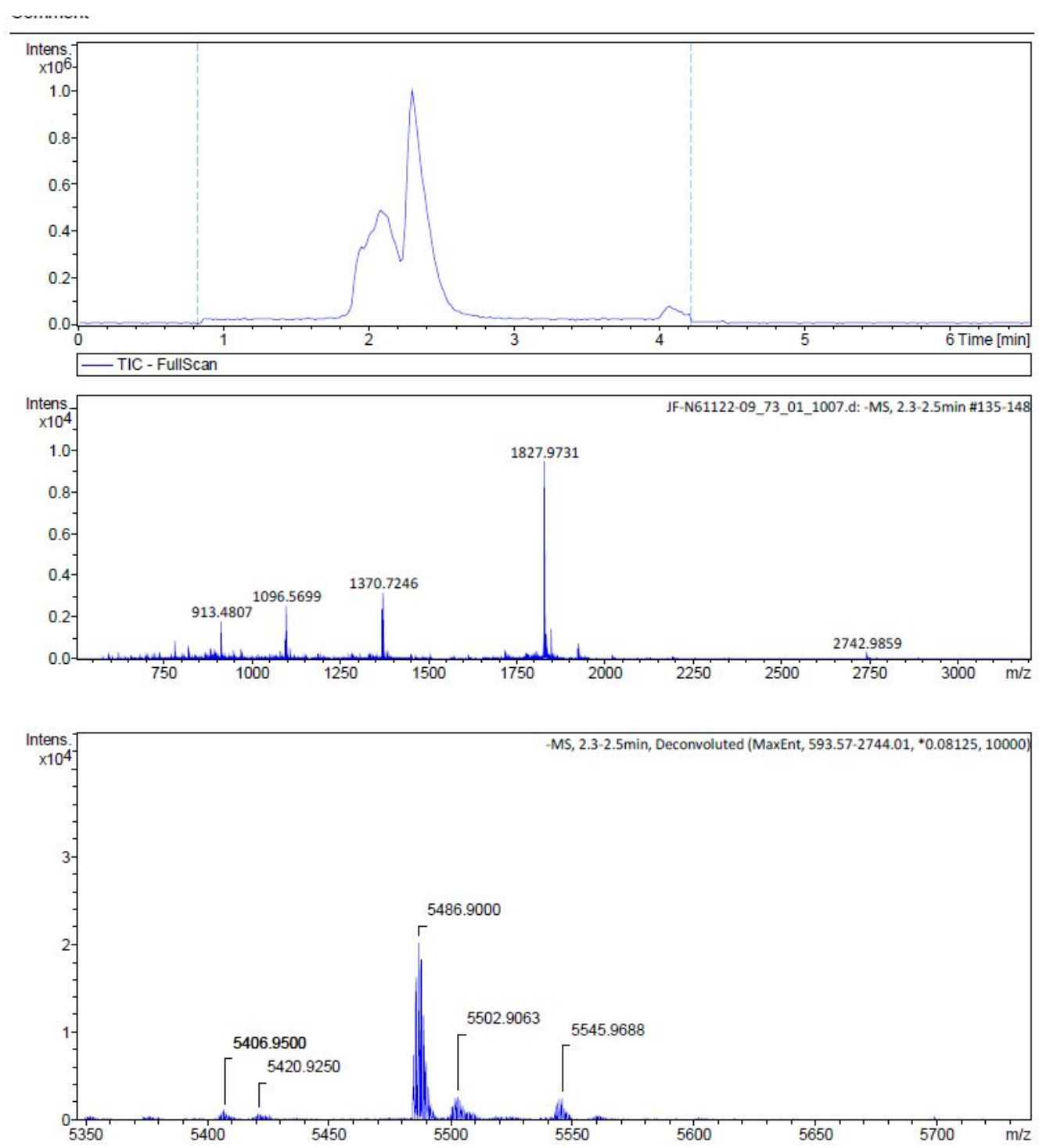

Figure S12. LCMS of HP-THP-Ph-NHR-NO (18), MW 5487.80, $\mathrm{C}_{181} \mathrm{H}_{245} \mathrm{~N}_{58} \mathrm{O}_{108} \mathrm{P}_{17}$. 


\section{Synthesis of HP-THP-Ph-NHR-NH 2 (19)}

In a $2 \mathrm{~mL}$ plastic tube, 40 equiv. of $\mathrm{FeSO}_{4}(12 \mu \mathrm{mol}$ in $60 \mu \mathrm{L}$ of water $)$ was added to a solution of HP-THP-Ph-NHR-NO $\mathbf{2}$ (18) $(300 \mathrm{nmol}$ in $300 \mu \mathrm{L}$ of $250 \mathrm{mM} \mathrm{pH} 9.4$ sodium borate buffer, with $10 \% \mathrm{v} / \mathrm{v} 1 \mathrm{M} \mathrm{NaOH}$ ) and vortexed. The reaction proceeded at $80{ }^{\circ} \mathrm{C}$ for $2 \mathrm{~h}$ and was monitored by LCMS (estimated LCMS conversion $>60 \%$ ). Once the reaction was deemed complete, the reaction mixture was centrifuged and a pipette was used to carefully remove the supernatant from the precipitate to follow the "EtOH Precipitation Protocol". The product was reconstituted in water at $2 \mathrm{mM}$ of HP-THP-Ph-NHR-NH $(\mathbf{1 9})$ for the next step.
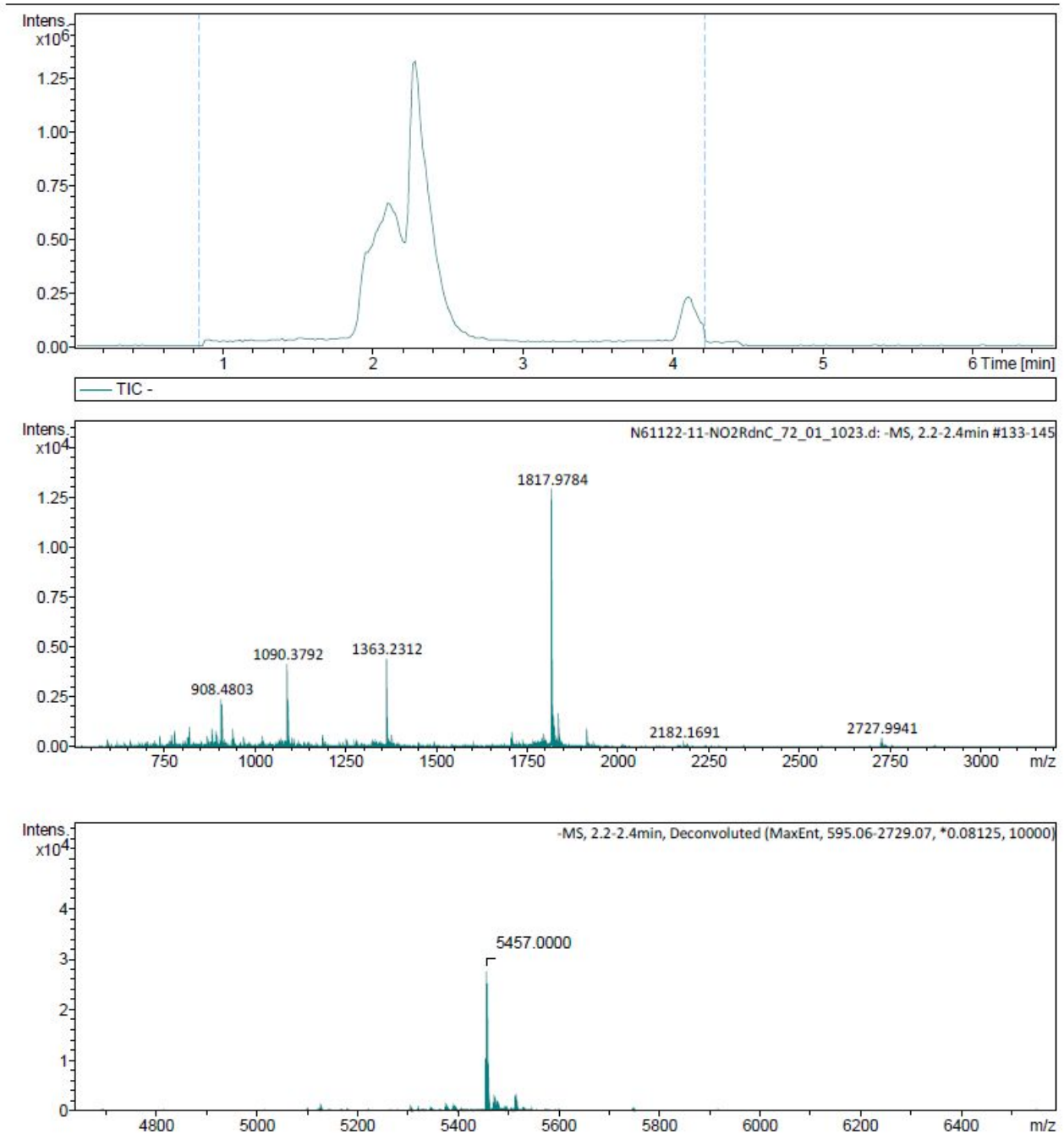

Figure S13. LCMS of HP-THP-Ph-NHR-NH2 (19), MW 5457.82, $\mathrm{C}_{181} \mathrm{H}_{247} \mathrm{~N}_{58} \mathrm{O}_{106} \mathrm{P}_{17}$. 


\section{Synthesis of HP-THP-Benzoimidazole (20)}

In a $2 \mathrm{~mL}$ plastic tube, 60 equiv. of 2-(4-chlorophenyl)-1H-imidazole-5-carbaldehyde (18 $\mu \mathrm{mol}$ in $90 \mu \mathrm{L}$ of DMA) was added to a solution of HP-THP-Ph-NHR-NH $(19)(300 \mathrm{nmol}$ in $300 \mu \mathrm{L}$ of $250 \mathrm{mM} \mathrm{pH} 5.5$ sodium phosphate buffer) and vortexed. The reaction was allowed to proceed at room temperature overnight and was monitored by LCMS (estimated LCMS conversion $>60 \%$ ). Once the reaction was complete, the "EtOH Precipitation Protocol" was followed and then the product was reconstituted in water at $2 \mathrm{mM}$ HP-THP-Benzimidazole (20) for the next step. 

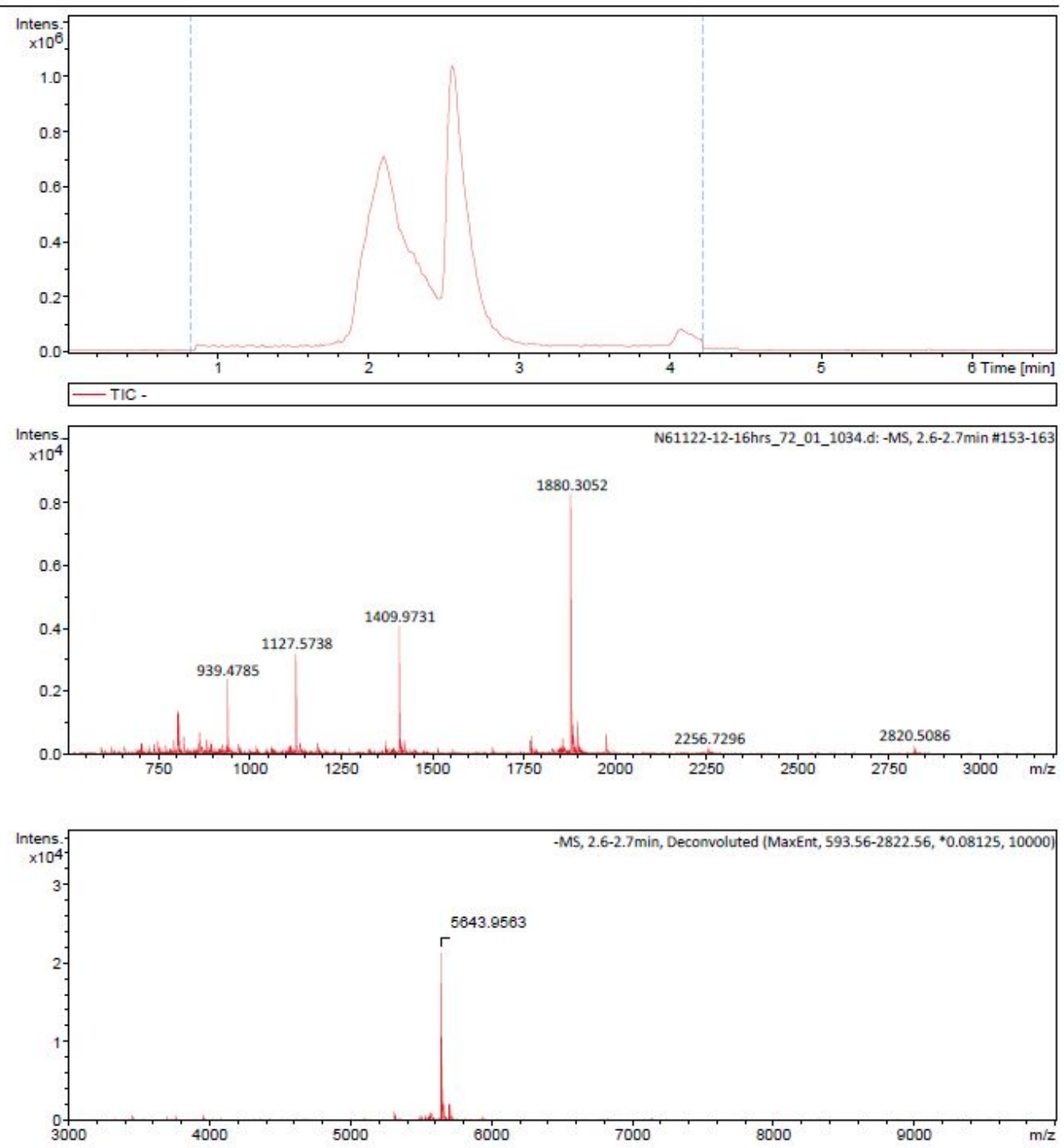

Figure S14. LCMS of HP-THP-Benzimidazole (20), MW 5644.42, $\mathrm{C}_{191} \mathrm{H}_{250} \mathrm{ClN}_{60} \mathrm{O}_{106} \mathrm{P}_{17}$.

\section{Detection of (21)}

The "General procedure for THP cleavage" described above was followed for the generation and detection of 21, also see part III AS-MS. LCMS $(m / z):[\mathrm{M}+\mathrm{H}]^{+}$calc'd for $\mathrm{C}_{22} \mathrm{H}_{22} \mathrm{ClN}_{5} \mathrm{O}_{3}, 440.14$; found, 440.25. 

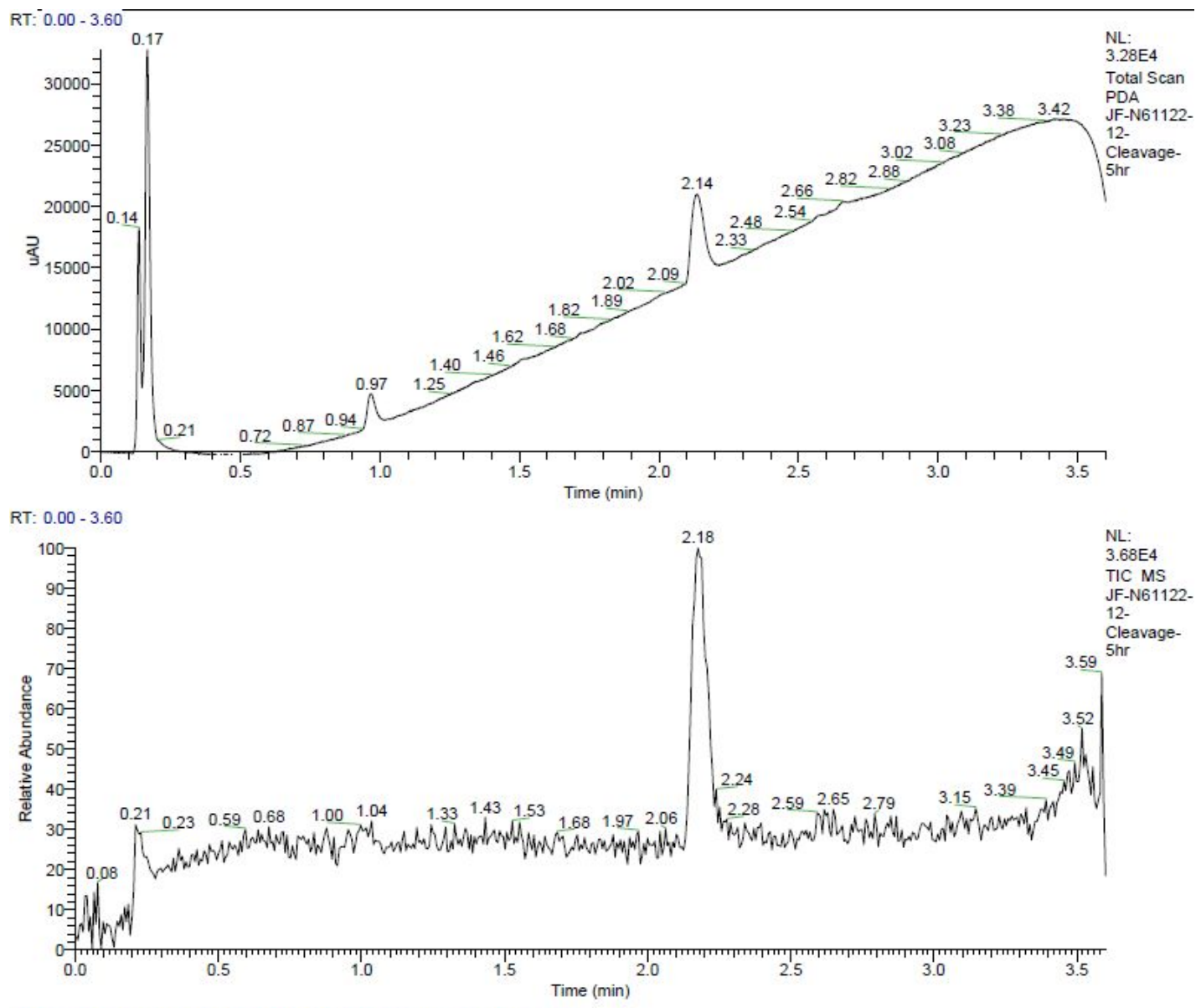

JF-N61122-12-Cleavage-5hr \#343-354 RT: $2.16-2.23$ AV: 12 NL: 9.33E3

T: ITMS + c ESI Full ms [60.00-1200.00]

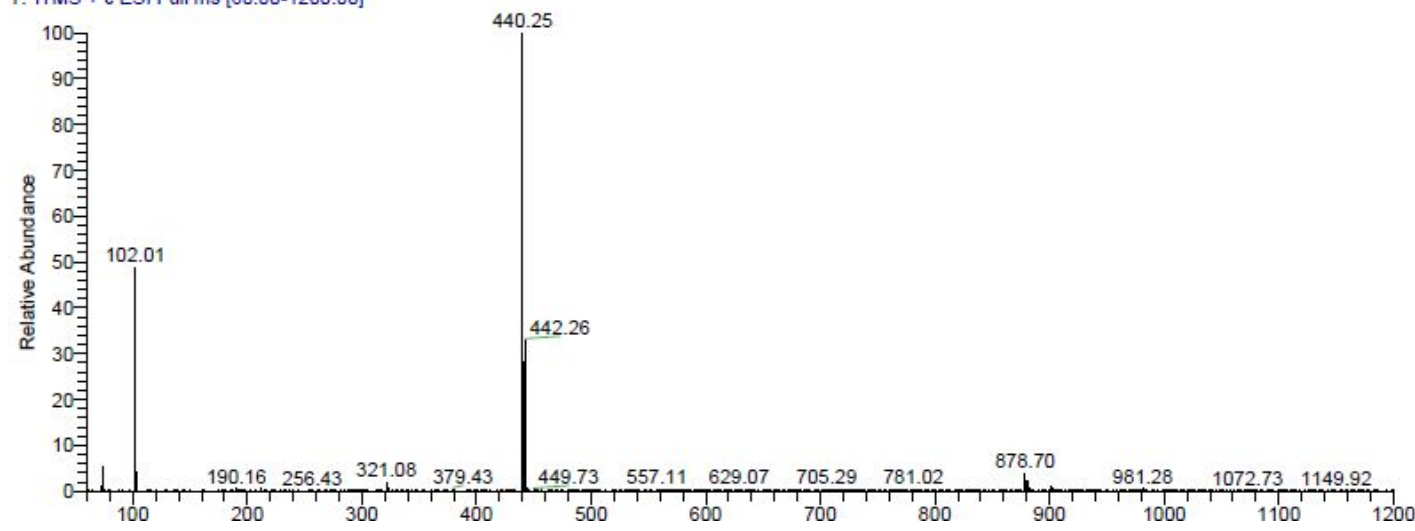

Figure S15. LCMS of 21

\section{Part II: Off-DNA chemistry}

Proton $\left({ }^{1} \mathrm{H}\right)$ NMR spectra were recorded at $400 \mathrm{MHz}$ at ambient temperature and chemical shifts are reported in parts per million. Data for ${ }^{1} \mathrm{H}$ NMR are reported as follows: chemical shift, , multiplicity $(\mathrm{s}=$ singlet, $\mathrm{d}=$ doublet, $\mathrm{t}=$ triplet, $\mathrm{q}=$ quartet, $\mathrm{m}=$ multiplet $)$, integration and 
coupling constants. All reagents were used as supplied by Sigma-Aldrich, unless otherwise stated. All reactions were carried out in oven-dried glassware, under an argon atmosphere unless otherwise noted.

Synthesis of 3-\{[(4-chloro-3-hydroxyphenyl)amino]methyl\}-5-(4-chloro-7-quinolinyl)-N-[2(methyloxy)ethyl]benzamide (1).

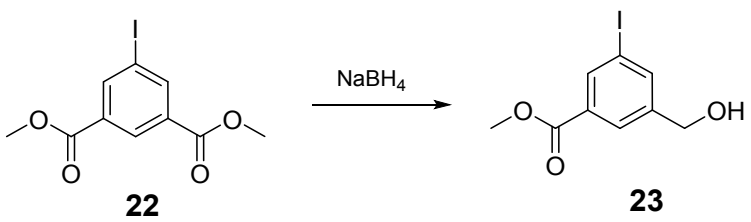

Step 1: To a heterogeneous mixture of dimethyl 5-iodo-1,3-benzenedicarboxylate (22, $3.50 \mathrm{~g}, 10.93 \mathrm{mmol})$ and sodium borohydride $(0.414 \mathrm{~g}, 10.93 \mathrm{mmol})$ in tetrahydrofuran (THF) (35 $\mathrm{mL})$ was added methanol $(5.0 \mathrm{~mL})$ dropwise. Evolution of gas was observed. The mixture was heated at $50{ }^{\circ} \mathrm{C}$ for $1 \mathrm{~h}$ during which time the reaction became homogeneous. LCMS analysis indicated the reaction was $\sim 60 \%$ desired product, $30 \%$ starting material, and $10 \%$ bis-reduced material. An additional $100 \mathrm{mg}$ of sodium borohydride was added and the reaction allowed to stir at $50{ }^{\circ} \mathrm{C}$ for an additional $\mathrm{h}$. LCMS analysis indicated that more of the starting material was consumed, but more undesired bis-reduced material was also present. A decision was made that the reaction had reached a point of diminishing returns. After cooling to room temperature, the solvent was removed under reduced pressure. The remaining residue was partitioned between ethyl acetate and water. The layers were separated, and the organic layer washed with brine and concentrated. Purification of the crude material by silica gel chromatography (CombiFlash; 1030\% ethyl acetate/hexanes) provided methyl 3-(hydroxymethyl)-5-iodobenzoate (23, $2.367 \mathrm{~g}$, 74\%) as a white solid. LCMS (m/z): [M+H] $]^{+}$calc'd for $\mathrm{C}_{9} \mathrm{H}_{10} \mathrm{IO}_{3}, 293.0$; found, 292.8. ${ }^{1} \mathrm{H}$ NMR $\left(400 \mathrm{MHz}, \mathrm{DMSO}-\mathrm{d}_{6}\right) \delta$ ppm $8.12-8.09(\mathrm{~m}, 1 \mathrm{H}), 7.96-7.91(\mathrm{~m}, 2 \mathrm{H}), 5.46(\mathrm{br} \mathrm{s}, 1 \mathrm{H}), 4.54(\mathrm{~s}$, 2H), $3.86(\mathrm{~s}, 3 \mathrm{H})$. 
${ }^{1} \mathrm{H}$ NMR of 23
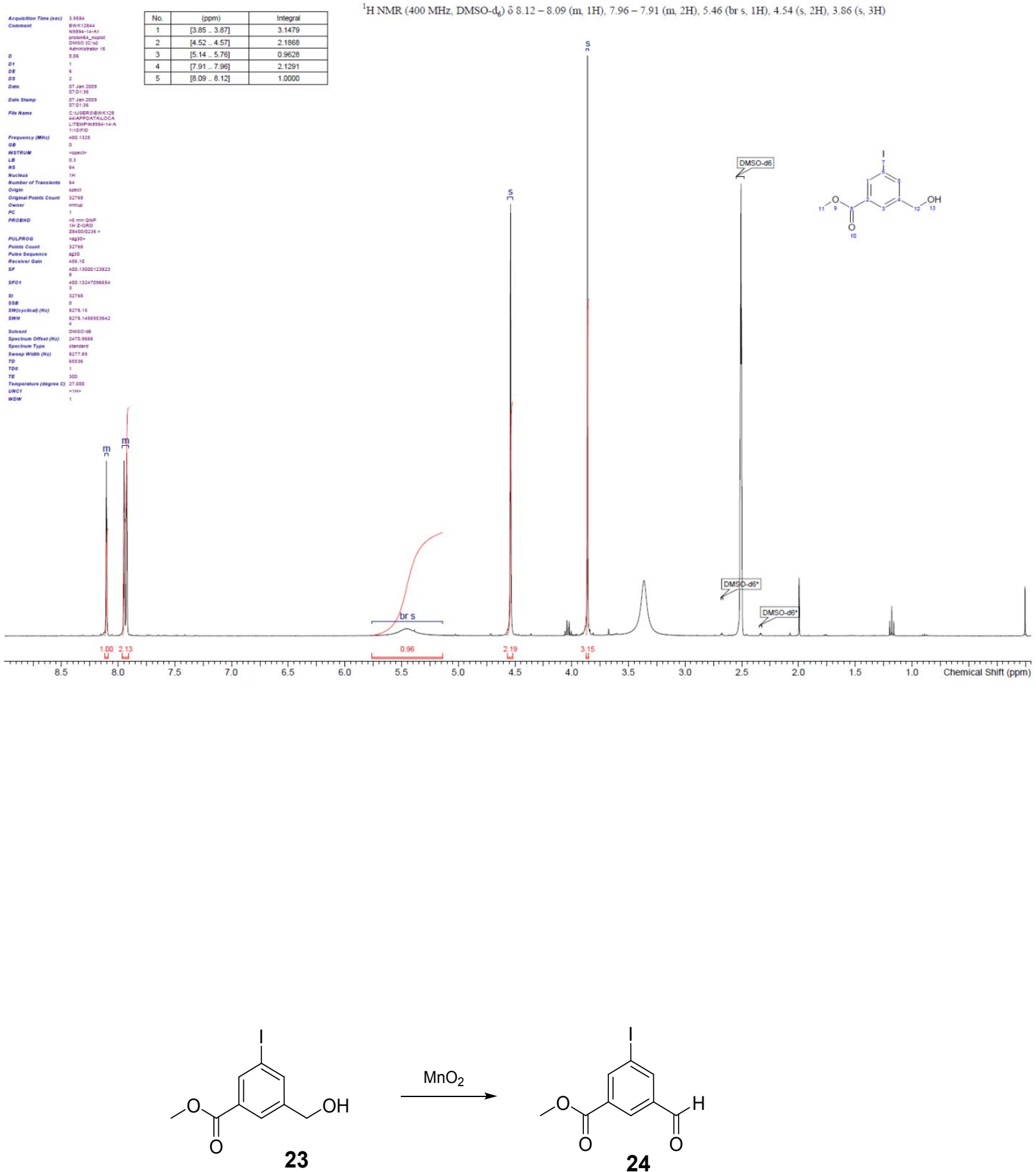

Step 2: A heterogeneous mixture of methyl 3-(hydroxymethyl)-5-iodobenzoate (23, $2.360 \mathrm{~g}, 8.08$ mmol) and manganese dioxide $(3.51 \mathrm{~g}, 40.4 \mathrm{mmol})$ in ethyl acetate $(20 \mathrm{~mL})$ was heated at reflux for $2.5 \mathrm{~h}$. Analysis of the reaction by LCMS confirmed $\sim 60 \%$ conversion to product. An 
additional $2.0 \mathrm{~g}$ of manganese dioxide was added and the reaction allowed to heat at reflux overnight $(\sim 15 \mathrm{~h})$. After cooling to room temperature, the reaction was filtered through a 0.45 micron PTFE filter and concentrated. Purification of the crude material by silica gel chromatography (CombiFlash; 0-35\% ethyl acetate/hexanes) provided methyl 3-formyl-5iodobenzoate $(\mathbf{2 4}, 1.360 \mathrm{~g}, 58 \%)$. LCMS $(\mathrm{m} / \mathrm{z})$ : $[\mathrm{M}+\mathrm{H}]^{+}$calc'd for $\mathrm{C}_{9} \mathrm{H}_{8} \mathrm{IO}_{3}, 290.9$; found, 290.8 . ${ }^{1} \mathrm{H}$ NMR (400 MHz, DMSO-d 6 ) $\delta$ ppm $10.02(\mathrm{~s}, 1 \mathrm{H}), 8.49(\mathrm{~d}, J=1.5 \mathrm{~Hz}, 2 \mathrm{H}), 8.42-8.40(\mathrm{~m}$, 1H), $3.91(\mathrm{~s}, 3 \mathrm{H})$.

${ }^{1} \mathrm{H}$ NMR of 24

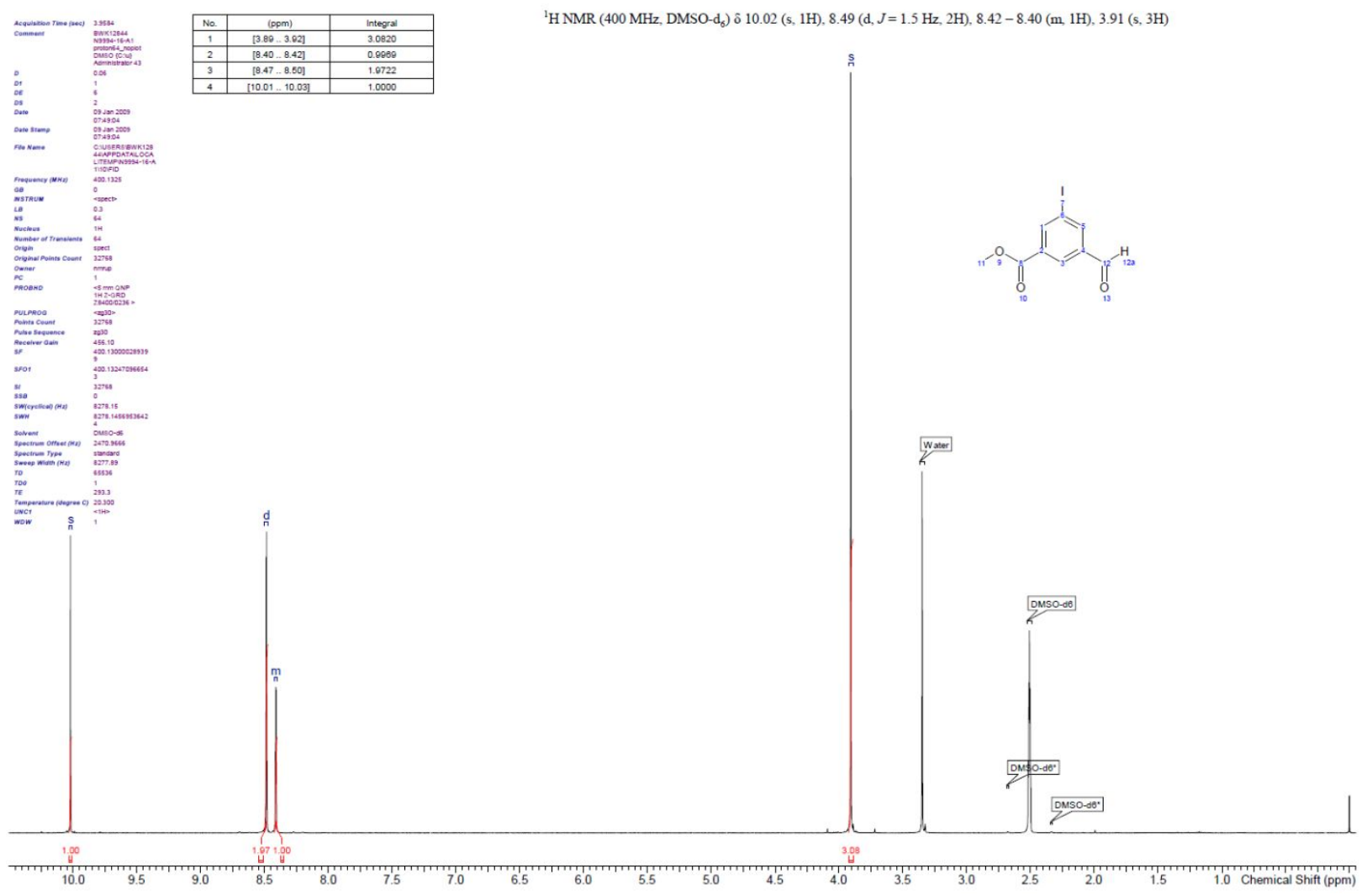




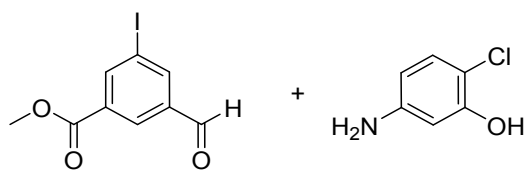

24
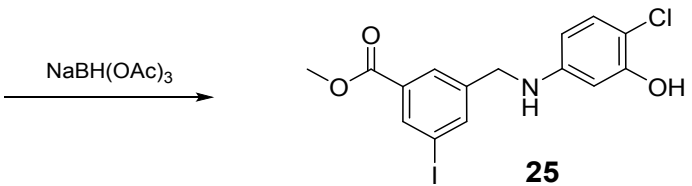

Step 3: To a heterogeneous mixture of methyl 3-formyl-5-iodobenzoate $(\mathbf{2 4}, 0.300 \mathrm{~g}, 1.034$ mmol), 5-amino-2-chlorophenol (0.156 g, $1.086 \mathrm{mmol})$, and acetic acid (0.062 mL, $1.086 \mathrm{mmol})$ in 1,2-dichloroethane (DCE) $(5 \mathrm{~mL})$ was added sodium triacetoxyborohydride $(0.263 \mathrm{~g}, 1.241$ mmol) in one portion. Over the next 1.5-2 $\mathrm{h}$, the reaction became homogeneous, then changed back to heterogeneous. The reaction was partitioned between ethyl acetate and $0.1 \mathrm{~N} \mathrm{NaOH}$ solution, and the layers were separated. The organic layer was washed with brine, dried over magnesium sulfate, and concentrated to give methyl 3-\{[(4-chloro-3hydroxyphenyl)amino]methyl $\}$-5-iodobenzoate $(\mathbf{2 5}, 430 \mathrm{mg}, 100 \%)$. LCMS $(\mathrm{m} / \mathrm{z}):[\mathrm{M}+\mathrm{H}]^{+}$and $[\mathrm{M}+2+\mathrm{H}]^{+}$calc'd for $\mathrm{C}_{15} \mathrm{H}_{14} \mathrm{ClINO}_{3}, 418.0$ and 420.0; found, 417.8 and 419.7. ${ }^{1} \mathrm{H}$ NMR (400 MHz, DMSO-d $\left.\mathrm{d}_{6}\right) \delta$ ppm $9.64(\mathrm{~s}, 1 \mathrm{H}), 8.12-8.08(\mathrm{~m}, 1 \mathrm{H}), 8.00-7.88(\mathrm{~m}, 2 \mathrm{H}), 6.94(\mathrm{~d}, J=8.6$ $\mathrm{Hz}, 1 \mathrm{H}), 6.48(\mathrm{t}, J=6.2 \mathrm{~Hz}, 1 \mathrm{H}), 6.15(\mathrm{~d}, J=2.5 \mathrm{~Hz}, 1 \mathrm{H}), 6.04(\mathrm{dd}, J=8.6,2.7 \mathrm{~Hz}, 1 \mathrm{H}), 4.26(\mathrm{~d}$, $J=6.1 \mathrm{~Hz}, 2 \mathrm{H}), 3.84(\mathrm{~s}, 3 \mathrm{H})$.

\section{${ }^{1} \mathrm{H}$ NMR of 25}



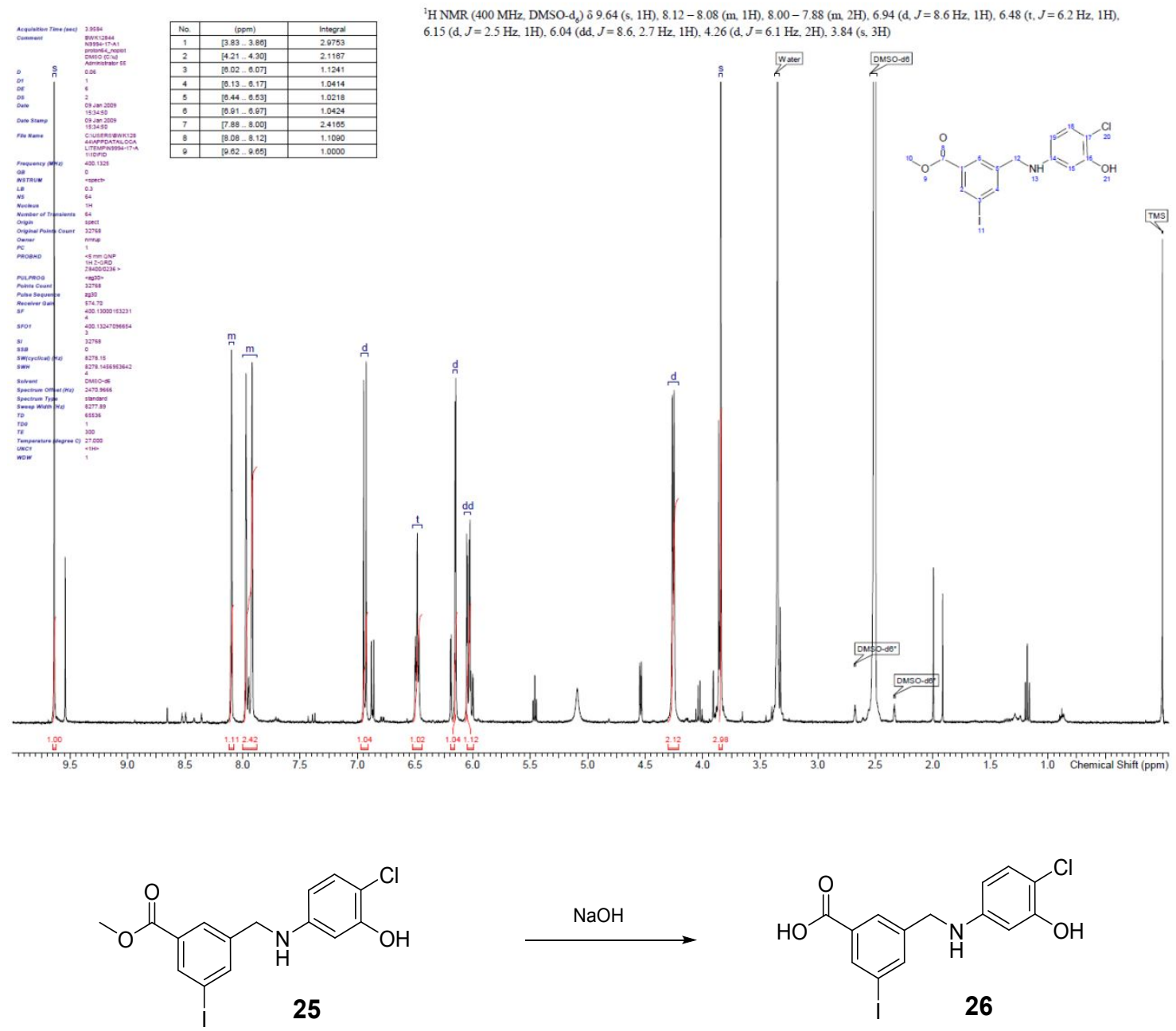

Step 4: A solution of methyl 3-\{[(4-chloro-3-hydroxyphenyl)amino]methyl\}-5-iodobenzoate (25, $0.430 \mathrm{~g}, 1.030 \mathrm{mmol})$ in 1,4-dioxane $(5 \mathrm{~mL})$ and sodium hydroxide solution $(2 \mathrm{M})(2.57 \mathrm{~mL}, 5.15$ mmol) was allowed to stir for $2 \mathrm{~h}$ at room temperature. The reaction was acidified to $\mathrm{pH} \sim 4$ by the addition of $2 \mathrm{M} \mathrm{HCl}$ solution $(\sim 2.6 \mathrm{~mL})$. A precipitate began to form. The reaction vessel was cooled to $0{ }^{\circ} \mathrm{C}$ with an ice/water bath. The mixture was filtered through a fritted funnel and the collected solid washed with a minimal amount of water and thoroughly dried to give $3-\{[(4$-chloro3-hydroxyphenyl)amino]methyl\}-5-iodobenzoic acid (26, 0.360 g, 87\%). LCMS $(\mathrm{m} / \mathrm{z})$ : $[\mathrm{M}+\mathrm{H}]^{+}$ and $[\mathrm{M}+2+\mathrm{H}]^{+}$calc'd for $\mathrm{C}_{14} \mathrm{H}_{12} \mathrm{ClINO}_{3}, 404.0$ and 406.0; found, 403.8 and 405.7. ${ }^{1} \mathrm{H}$ NMR (400 MHz, DMSO-d 6 ) $\delta$ ppm $13.27($ br s, $1 \mathrm{H}), 9.64(\mathrm{~s}, 1 \mathrm{H}), 8.08(\mathrm{t}, J=1.5 \mathrm{~Hz}, 1 \mathrm{H}), 7.95-7.88$ 
(m, 2H), $6.94(\mathrm{~d}, J=8.8 \mathrm{~Hz}, 1 \mathrm{H}), 6.47(\mathrm{br} \mathrm{t}, J=6.1 \mathrm{~Hz}, 1 \mathrm{H}), 6.15(\mathrm{~d}, J=2.8 \mathrm{~Hz}, 1 \mathrm{H}), 6.04$ (dd, $J$

$=8.6,2.5 \mathrm{~Hz}, 1 \mathrm{H}), 4.25($ br d, $J=5.1 \mathrm{~Hz}, 2 \mathrm{H})$.

${ }^{1} \mathrm{H}$ NMR of 26
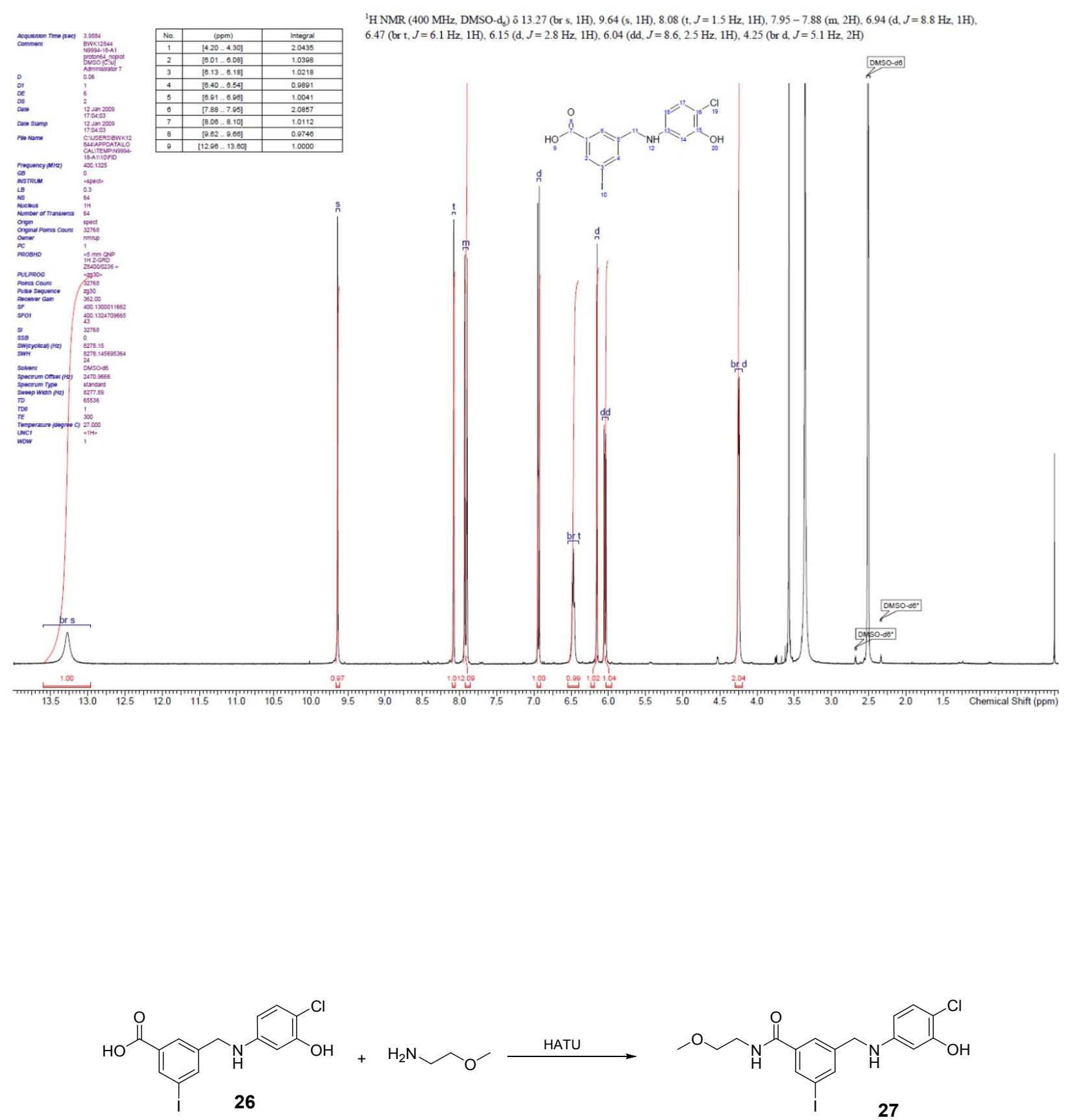
Step 5: To a solution of 3-\{[(4-chloro-3-hydroxyphenyl)amino $]$ methyl $\}$-5-iodobenzoic acid (26, $0.100 \mathrm{~g}, 0.248 \mathrm{mmol}), 2-\mathrm{methoxyethylamine}(0.023 \mathrm{~mL}, 0.260 \mathrm{mmol})$, and DIEA (0.043 $\mathrm{mL}$, $0.248 \mathrm{mmol})$ in $N, N$-Dimethylformamide (DMF) $(2 \mathrm{~mL})$ was added HATU $(0.099 \mathrm{~g}, 0.260 \mathrm{mmol})$ in one portion. The reaction was allowed to stir for $30 \mathrm{~min}$. LCMS analysis indicated approximately $40 \%$ starting material remained. A second portion of 2-methoxyethylamine $(0.023$ $\mathrm{mL}$ ) and HATU (99 mg) was sequentially added. The reaction was allowed to stir for $1 \mathrm{~h}$. The reaction was partitioned between ethyl acetate and water. The layers were separated, and the organic layer washed with brine, and concentrated. Purification of the crude material by silica gel chromatography (CombiFlash; 20-60\% ethyl acetate/hexanes) provided 3-\{[(4-chloro-3hydroxyphenyl)amino]methyl\}-5-iodo-N-[2-(methyloxy)ethyl]benzamide $(27,98 \mathrm{mg}, 86 \%)$. LCMS $(m / z):[\mathrm{M}+\mathrm{H}]^{+}$and $[\mathrm{M}+2+\mathrm{H}]^{+}$calc'd for $\mathrm{C}_{17} \mathrm{H}_{19} \mathrm{ClIN}_{2} \mathrm{O}_{3}, 461.0$ and 463.0; found, 461.0 and 462.9. ${ }^{1} \mathrm{H}$ NMR (400 MHz, METHANOL-d 4 ) $\delta$ ppm $8.03(\mathrm{~s}, 1 \mathrm{H}), 7.90-7.74(\mathrm{~m}, 2 \mathrm{H}), 6.95$ (br d, $J=8.3 \mathrm{~Hz}, 1 \mathrm{H}), 6.15-6.07(\mathrm{~m}, 2 \mathrm{H}), 4.28(\mathrm{~s}, 2 \mathrm{H}), 3.56-3.50(\mathrm{~m}, 4 \mathrm{H}), 3.36(\mathrm{~s}, 3 \mathrm{H})$. 
${ }^{1} \mathrm{H}$ NMR of 27
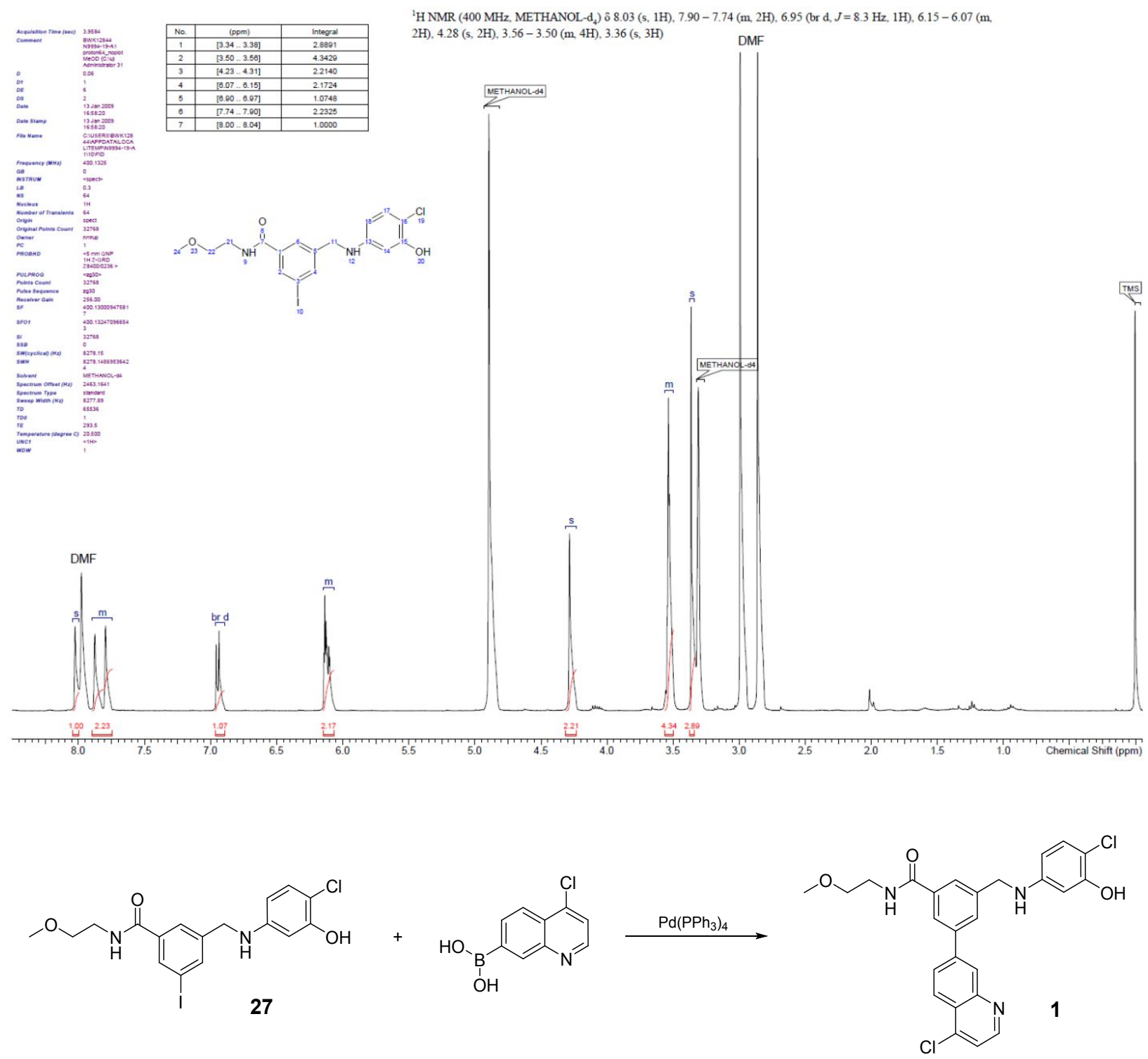

Step 6: To a solution of $3-\{[(4-c h l o r o-3-h y d r o x y p h e n y l) a m i n o] m e t h y l\}-5-i o d o-N-[2-$ (methyloxy)ethyl]benzamide $(\mathbf{2 7}, 0.090 \mathrm{~g}, 0.195 \mathrm{mmol})$ in 1,2-dimethoxyethane (DME) (2 mL) was added palladium tetrakis $(0.011 \mathrm{~g}, 9.77 \mu \mathrm{mol})$ in one portion. The reaction was purged with nitrogen gas and the vessel sealed. After stirring for $\sim 10 \mathrm{~min}$, (4-chloro-7-quinolinyl)boronic acid (0.041 g, $0.195 \mathrm{mmol})$ and sodium carbonate solution $(0.195 \mathrm{~mL}, 0.391 \mathrm{mmol})$ were sequentially added. This heterogeneous mixture was irradiated in a microwave reactor at $100{ }^{\circ} \mathrm{C}$ for $30 \mathrm{~min}$. The reaction was filtered through a 0.45 micron PTFE acrodisc and diluted with DMSO. S 33 
Purification of the crude material using reverse phase HPLC [40-65\% acetonitrile:water $(0.1 \%$ $\mathrm{NH}_{4} \mathrm{OH}$ modifier), $30 \mathrm{~mm}$ Gemini column, $\left.47 \mathrm{~mL} / \mathrm{min}\right]$ gave 3-\{[(4-chloro-3hydroxyphenyl)amino]methyl\}-5-(4-chloro-7-quinolinyl)-N-[2-(methyloxy)ethyl]benzamide (1) (20 $\mathrm{mg}, 21 \%)(\mathrm{RT}=6.9 \mathrm{~min})$ as a white solid. $\operatorname{LCMS}(\mathrm{m} / \mathrm{z}):[\mathrm{M}+\mathrm{H}]^{+}$and $[\mathrm{M}+2+\mathrm{H}]^{+}$calc'd for $\mathrm{C}_{26} \mathrm{H}_{24} \mathrm{Cl}_{2} \mathrm{~N}_{3} \mathrm{O}_{3}, 496.1$ and 498.1; found, 496.0 and 498.1. ${ }^{1} \mathrm{H}$ NMR (400 MHz, DMSO-d $\left.\mathrm{d}_{6}\right) \delta \mathrm{ppm}$ $9.63($ br s, $1 \mathrm{H}), 8.90(\mathrm{~d}, J=4.5 \mathrm{~Hz}, 1 \mathrm{H}), 8.85-8.74(\mathrm{~m}, 1 \mathrm{H}), 8.50(\mathrm{~d}, J=1.8 \mathrm{~Hz}, 1 \mathrm{H}), 8.32(\mathrm{~d}, J$ $=8.6 \mathrm{~Hz}, 1 \mathrm{H}), 8.27-8.22(\mathrm{~m}, 1 \mathrm{H}), 8.18(\mathrm{dd}, J=8.7,1.9 \mathrm{~Hz}, 1 \mathrm{H}), 8.05-7.98(\mathrm{~m}, 1 \mathrm{H}), 7.95-7.90$ (m, 1H), $7.79(\mathrm{~d}, J=4.8 \mathrm{~Hz}, 1 \mathrm{H}), 6.93(\mathrm{~d}, J=8.6 \mathrm{~Hz}, 1 \mathrm{H}), 6.49(\mathrm{t}, J=6.1 \mathrm{~Hz}, 1 \mathrm{H}), 6.23(\mathrm{~d}, J=$ $2.5 \mathrm{~Hz}, 1 \mathrm{H}), 6.11(\mathrm{dd}, J=8.7,2.7 \mathrm{~Hz}, 1 \mathrm{H}), 4.36(\mathrm{~d}, J=5.8 \mathrm{~Hz}, 2 \mathrm{H}), 3.52-3.45(\mathrm{~m}, 4 \mathrm{H}), 3.28(\mathrm{~s}$, $3 \mathrm{H})$. LCMS purity $=97 \%$ by UV at $214 \mathrm{~nm}$.

${ }^{1} \mathrm{H}$ NMR of 1

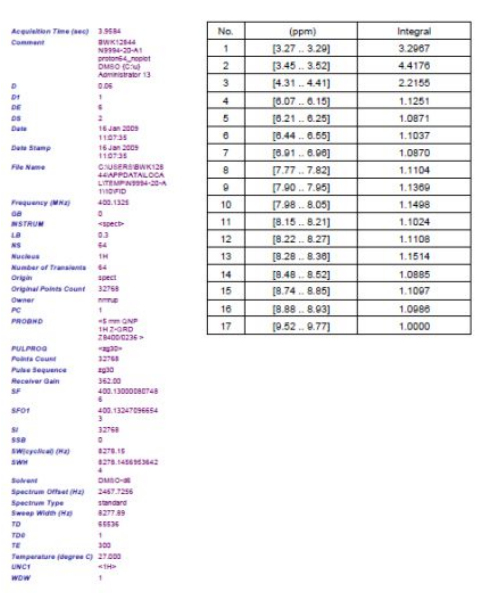

${ }^{1} \mathrm{H}$ NMR $\left(400 \mathrm{MHz}, \mathrm{DMSO}-\mathrm{d}_{\mathrm{f}}\right) 69.63$ (br s, $\left.1 \mathrm{H}\right), 8.90(\mathrm{~d}, J=4.5 \mathrm{~Hz}, 1 \mathrm{H}), 8.85-8.74(\mathrm{~m}, 1 \mathrm{H}), 8.50(\mathrm{~d}, J=1.8 \mathrm{~Hz}, 1 \mathrm{H}), 8.32(\mathrm{~d}, J=8.6 \mathrm{~Hz}, 1 \mathrm{H})$ $8.27-8.22(\mathrm{~m}, 1 \mathrm{H}), 8.18(\mathrm{dd}, J=8.7,1.9 \mathrm{~Hz}, 1 \mathrm{H}), 8.05-7.98(\mathrm{~m}, 1 \mathrm{H}), 7.95-7.90(\mathrm{~m}, 1 \mathrm{H}), 7.79(\mathrm{~d}, J=4.8 \mathrm{~Hz}, 1 \mathrm{H}), 6.93(\mathrm{~d}, J=8.6 \mathrm{~Hz}, 1 \mathrm{H})$ $6.49(\mathrm{t}, J=6.1 \mathrm{~Hz}, 1 \mathrm{H}), 6.23(\mathrm{~d}, J=2.5 \mathrm{~Hz}, 1 \mathrm{H}), 6.11(\mathrm{dd}, J=8.7,2.7 \mathrm{~Hz}, 1 \mathrm{H}), 4.36(\mathrm{~d}, J=5.8 \mathrm{~Hz}, 2 \mathrm{H}), 3.52-3.45(\mathrm{~m}, 4 \mathrm{H}), 3.28(\mathrm{~s}, 3 \mathrm{H})$
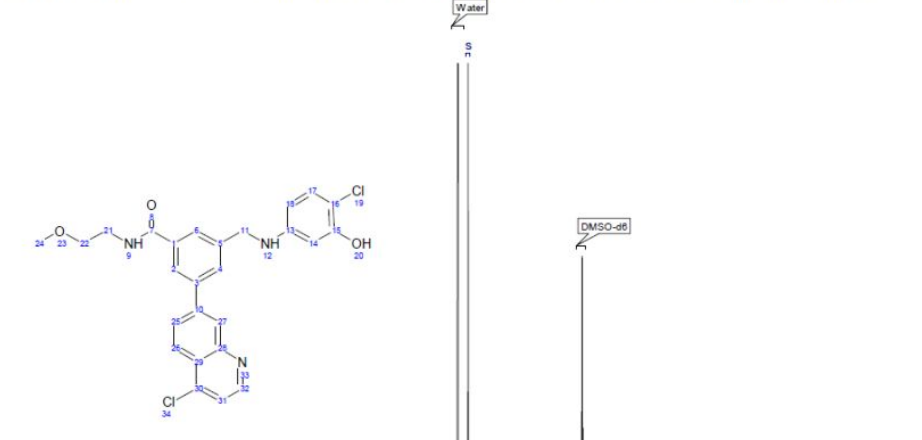
Synthesis of 3-((4-chloro-3-hydroxyphenyl)amino)methyl)-5-(4-((4-chloro-3hydroxyphenyl)amino)quinolin-7-yl)-N-(2-methoxyethyl)benzamide (2)
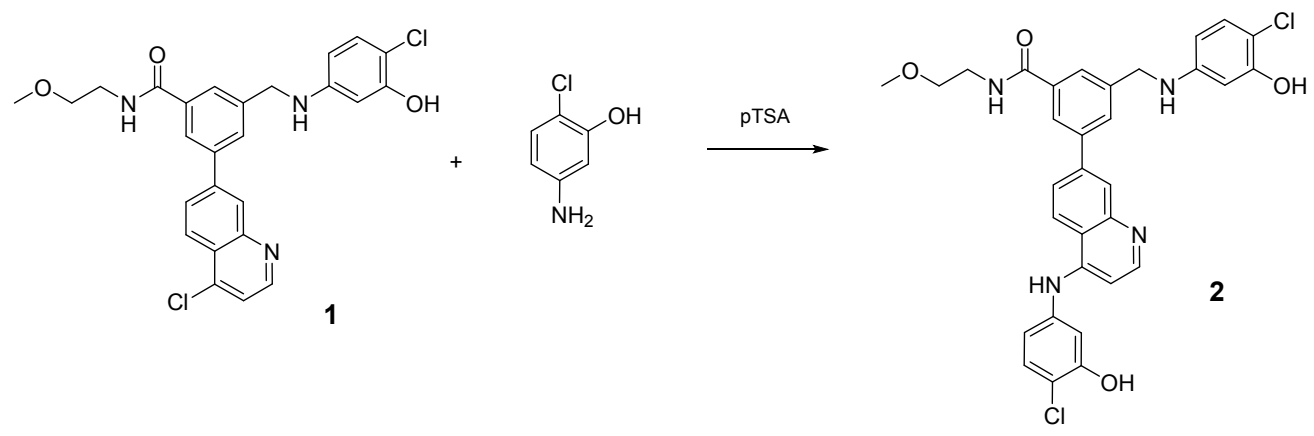

A solution of 3-\{[(4-chloro-3-hydroxyphenyl)amino]methyl $\}-5-(4-c h l o r o-7-q u i n o l i n y l)-N-[2-$ (methyloxy)ethyl]benzamide (1) (5 mg, $0.010 \mathrm{mmol}$ ), 5-amino-2-chlorophenol (1.45 mg, 0.010 $\mathrm{mmol})$, and p-toluenesulfonic acid monohydrate $(0.96 \mathrm{mg}, 0.005 \mathrm{mmol})$ in dimethyl sulfoxide $(0.5$ $\mathrm{mL}$ ) was irradiated in a microwave reactor at $80{ }^{\circ} \mathrm{C}$ for $30 \mathrm{~min}$. Purification of the crude material using reverse phase HPLC [40-70\% acetonitrile:water (0.1\% TFA modifier), $30 \mathrm{~mm}$ Luna column, $47 \mathrm{~mL} / \mathrm{min}] \quad$ gave 3-((4-chloro-3-hydroxyphenyl)amino)methyl)-5-(4-((4-chloro-3hydroxyphenyl)amino)quinolin-7-yl)-N-(2-methoxyethyl)benzamide (2) (1.83 mg, 30\%). LCMS $(m / z):[\mathrm{M}+\mathrm{H}]^{+}$and $[\mathrm{M}+2+\mathrm{H}]^{+}$calc'd for $\mathrm{C}_{32} \mathrm{H}_{28} \mathrm{Cl}_{2} \mathrm{~N}_{4} \mathrm{O}_{4}, 603.1$ and 605.1; found, 603.3 and 605.5. ${ }^{1} \mathrm{H}$ NMR (400 MHz, ACETONITRILE-d ${ }_{3}$ ) $\delta$ ppm 14.01 (br s, 1H), $9.38-9.23$ (m, 1H), $8.51-$ $8.11(\mathrm{~m}, 4 \mathrm{H}), 8.02-7.92(\mathrm{~m}, 1 \mathrm{H}), 7.90-7.74(\mathrm{~m}, 3 \mathrm{H}), 7.64-7.54(\mathrm{~m}, 1 \mathrm{H}), 7.49-7.40(\mathrm{~m}, 1 \mathrm{H})$ $7.13-7.04(\mathrm{~m}, 1 \mathrm{H}), 7.03-6.94(\mathrm{~m}, 1 \mathrm{H}), 6.94-6.78(\mathrm{~m}, 2 \mathrm{H}), 6.34-6.13(\mathrm{~m}, 2 \mathrm{H}), 4.36(\mathrm{~s}, 2 \mathrm{H})$, $3.63-3.52(\mathrm{~m}, 4 \mathrm{H}), 3.35(\mathrm{~s}, 3 \mathrm{H})$. LCMS purity $=97 \%$ by UV at $214 \mathrm{~nm}$. 
${ }^{1} \mathrm{H}$ NMR of 2

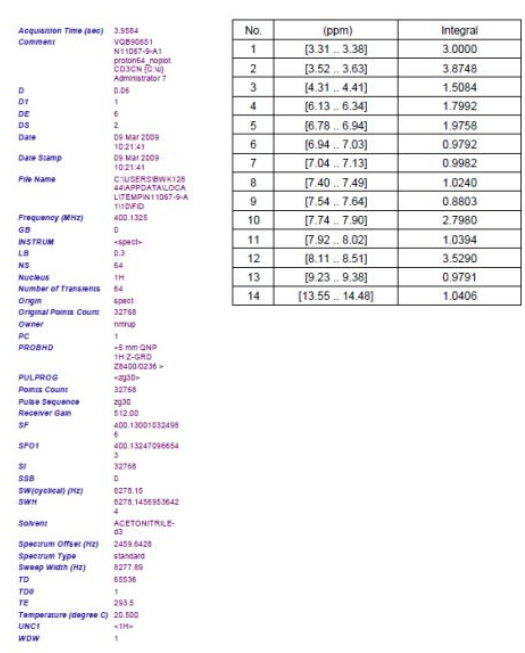

${ }^{1}{ }^{H}$ NMR (400 MHz, ACETONITRILE-d 3 ) $\delta 14.01$ (br s, 1H), 9.38-9.23 (m, 1H), $8.51-8.11(\mathrm{~m}, 4 \mathrm{H}), 8.02-7.92(\mathrm{~m}, 1 \mathrm{H}), 7.90-7.74(\mathrm{~m}, 3 \mathrm{H})$, $7.64-7.54(\mathrm{~m}, 1 \mathrm{H}), 7.49-7.40(\mathrm{~m}, 1 \mathrm{H}), 7.13-7.04(\mathrm{~m}, 1 \mathrm{H}), 7.03-6.94(\mathrm{~m}, 1 \mathrm{H}), 6.94-6.78(\mathrm{~m}, 2 \mathrm{H}), 6.34-6.13(\mathrm{~m}, 2 \mathrm{H}), 4.36(\mathrm{~s}, 2 \mathrm{H}), 3.63-$ $3.52(\mathrm{~m}, 4 \mathrm{H}), 3.35(\mathrm{~s}, 3 \mathrm{H})$
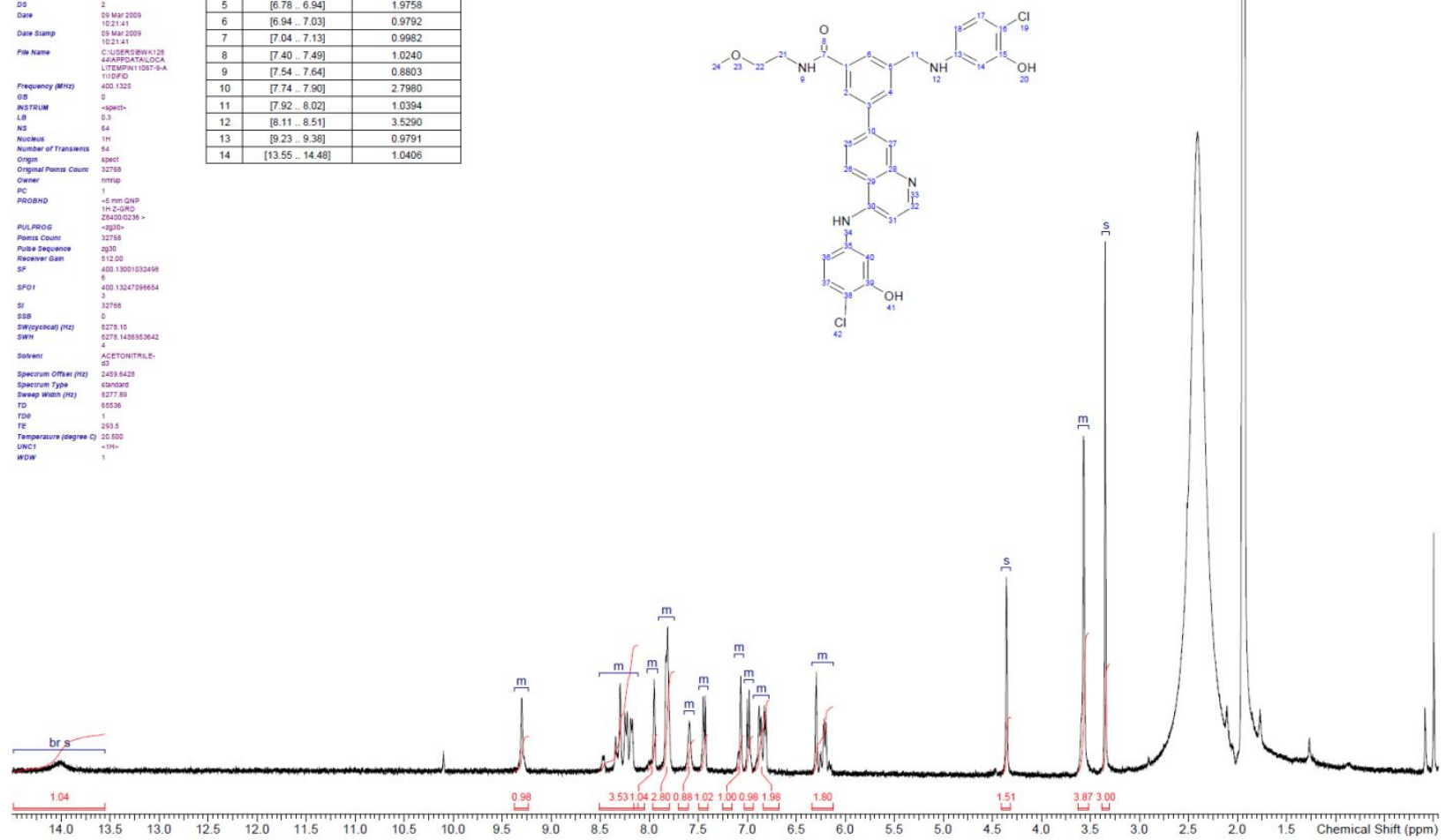

Synthesis 2-chloro-5-[(7-phenyl-4-quinolinyl)amino]phenol (3)<smiles>Clc1ccnc2cc(I)ccc12</smiles><smiles>Nc1ccc(Cl)c(O)c1</smiles>

PTSA<smiles>Oc1cc(Nc2ccnc3cc(I)ccc23)ccc1Cl</smiles> 
Step 1: A mixture of 4-chloro-7-iodoquinoline (0.135 g, $0.466 \mathrm{mmol})$, 5-amino-2-chlorophenol (0.067 g, $0.466 \mathrm{mmol})$, and p-toluenesulfonic acid monohydrate $(4.44 \mathrm{mg}, 0.023 \mathrm{mmol})$ in dimethyl sulfoxide (DMSO) $(2 \mathrm{~mL})$ was irradiated in a microwave reactor at $100{ }^{\circ} \mathrm{C}$ for $30 \mathrm{~min}$. The addition of water resulted in a precipitation. The mixture was filtered and the collected solid washed with water and thoroughly dried to give 2-chloro-5-[(7-iodo-4-quinolinyl)amino]phenol (28, $165 \mathrm{mg}, 89 \%)$. LCMS $(\mathrm{m} / \mathrm{z}):[\mathrm{M}+\mathrm{H}]^{+}$and $[\mathrm{M}+2+\mathrm{H}]^{+}$calc'd for $\mathrm{C}_{15} \mathrm{H}_{11} \mathrm{ClIN}_{2} \mathrm{O}, 397.0$ and 399.0; found, 396.5 and 398.7. ${ }^{1} \mathrm{H}$ NMR (400 MHz, DMSO-d 6 ) $\delta$ ppm 10.92 (br s, $\left.1 \mathrm{H}\right), 10.83-$ $10.78(\mathrm{~m}, 1 \mathrm{H}), 8.52-8.46(\mathrm{~m}, 2 \mathrm{H}), 8.44-8.42(\mathrm{~m}, 1 \mathrm{H}), 8.12(\mathrm{dd}, J=9.0,1.6 \mathrm{~Hz}, 1 \mathrm{H}), 7.51(\mathrm{~d}, J$ $=8.5 \mathrm{~Hz}, 1 \mathrm{H}), 7.10-7.07(\mathrm{~m}, 1 \mathrm{H}), 6.95-6.90(\mathrm{~m}, 1 \mathrm{H}), 6.88(\mathrm{~d}, J=7.0 \mathrm{~Hz}, 1 \mathrm{H})$.

${ }^{1} \mathrm{H}$ NMR of $\mathbf{2 8}$

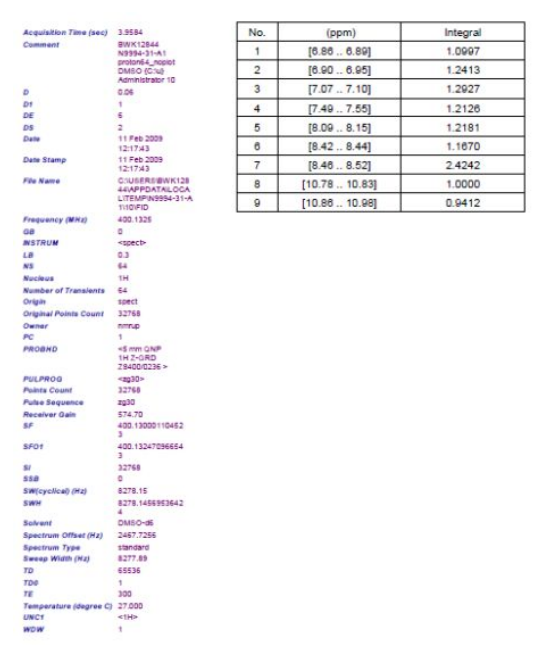

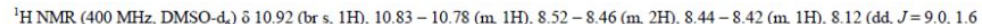
$\mathrm{Hz}, 1 \mathrm{H}), 7.51(\mathrm{~d}, J=8.5 \mathrm{~Hz}, 1 \mathrm{H}), 7.10-7.07(\mathrm{~m}, 1 \mathrm{H}), 6.95-6.90(\mathrm{~m}, 1 \mathrm{H}), 6.88(\mathrm{~d}, J=7.0 \mathrm{~Hz}, 1 \mathrm{H})$
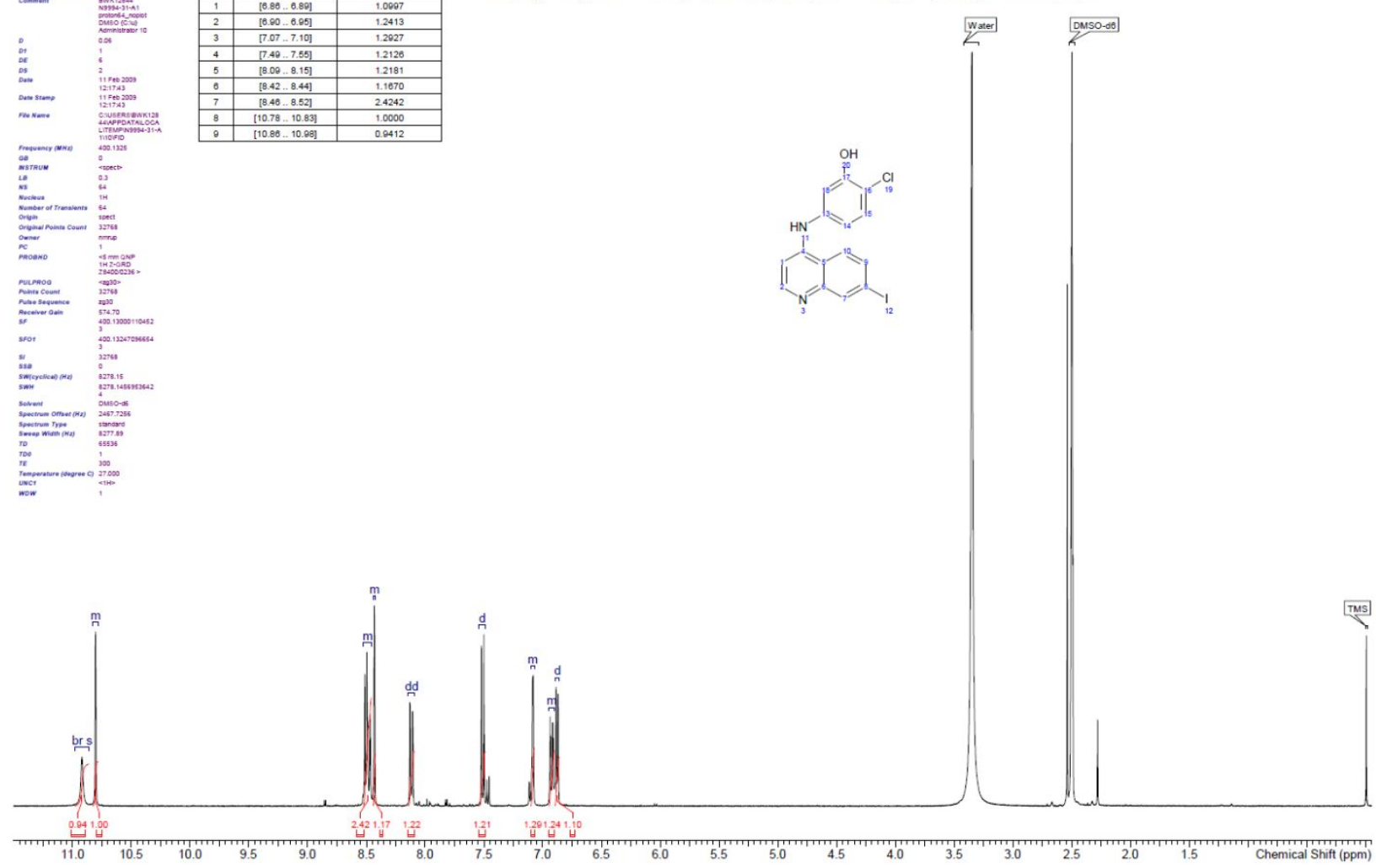

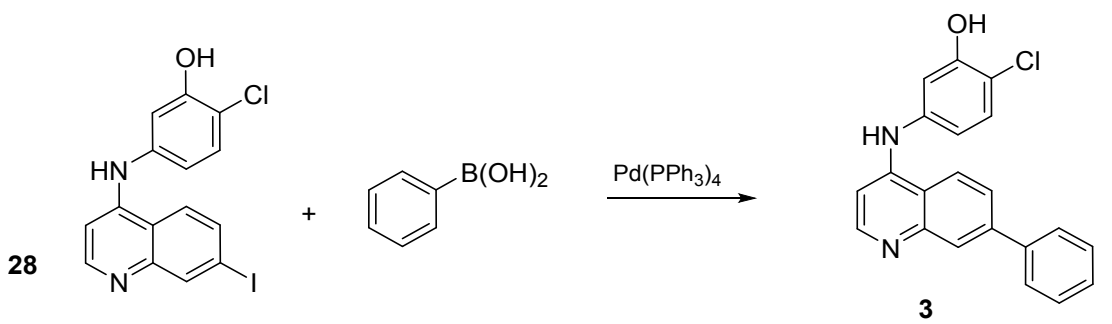

Step 2: A mixture of 2-chloro-5-[(7-iodo-4-quinolinyl)amino]phenol (28, $0.070 \mathrm{~g}, 0.176 \mathrm{mmol})$, phenylboronic acid (0.022 g, $0.176 \mathrm{mmol})$, and palladium tetrakis $(10.20 \mathrm{mg}, 8.82 \mu \mathrm{mol})$ in $1,2-$ dimethoxyethane (DME) $(2 \mathrm{~mL})$ and $2 \mathrm{M}$ sodium carbonate solution $(0.176 \mathrm{~mL}, 0.353 \mathrm{mmol})$ was irradiated in a microwave reactor at $100{ }^{\circ} \mathrm{C}$ for $30 \mathrm{~min}$. Analysis of the reaction by LCMS indicated 2/3 starting material remained. Another $5 \mathrm{mg}$ of palladium tetrakis was added and the mixture irradiated at $120^{\circ} \mathrm{C}$ for $30 \mathrm{~min}$. The reaction was filtered through a 0.45 micron PTFE acrodisc and diluted with DMSO. Purification of the crude material using reverse phase HPLC [30-60\% acetonitrile:water ( $0.1 \%$ TFA modifier), $30 \mathrm{~mm}$ Luna column, $47 \mathrm{~mL} / \mathrm{min}$ ] gave 2 chloro-5-[(7-phenyl-4-quinolinyl)amino]phenol (3) (30 mg, 37\%) (RT=5.8 min) as a light yellow solid. LCMS $(\mathrm{m} / \mathrm{z})$ : $[\mathrm{M}+\mathrm{H}]^{+}$and $[\mathrm{M}+2+\mathrm{H}]^{+}$calc'd for $\mathrm{C}_{21} \mathrm{H}_{16} \mathrm{ClN}_{2} \mathrm{O}, 347.1$ and 349.1; found, 346.9 and 348.9. ${ }^{1} \mathrm{H}$ NMR (400 MHz, DMSO-d $\left.\mathrm{d}_{6}\right) \delta \mathrm{ppm} 14.22$ (br s, $\left.1 \mathrm{H}\right), 10.83-10.76(\mathrm{~m}, 1 \mathrm{H})$, $8.75(\mathrm{~d}, J=9.3 \mathrm{~Hz}, 1 \mathrm{H}), 8.58(\mathrm{~d}, J=7.1 \mathrm{~Hz}, 1 \mathrm{H}), 8.23-8.17(\mathrm{~m}, 2 \mathrm{H}), 7.91-7.86(\mathrm{~m}, 2 \mathrm{H}), 7.65$ $-7.58(\mathrm{~m}, 2 \mathrm{H}), 7.58-7.51(\mathrm{~m}, 2 \mathrm{H}), 7.09-7.05(\mathrm{~m}, 1 \mathrm{H}), 6.99-6.89(\mathrm{~m}, 2 \mathrm{H})$. HRMS $(\mathrm{m} / \mathrm{z})$ : $[\mathrm{M}+\mathrm{H}]^{+}$calc'd for $\mathrm{C}_{21} \mathrm{H}_{16} \mathrm{ClN}_{2} \mathrm{O}, 347.0951$; found, 347.0951. LCMS purity $=100 \%$ by $\mathrm{UV}$ at 214 $\mathrm{nm}$. 
${ }^{1} \mathrm{H}$ NMR of 3

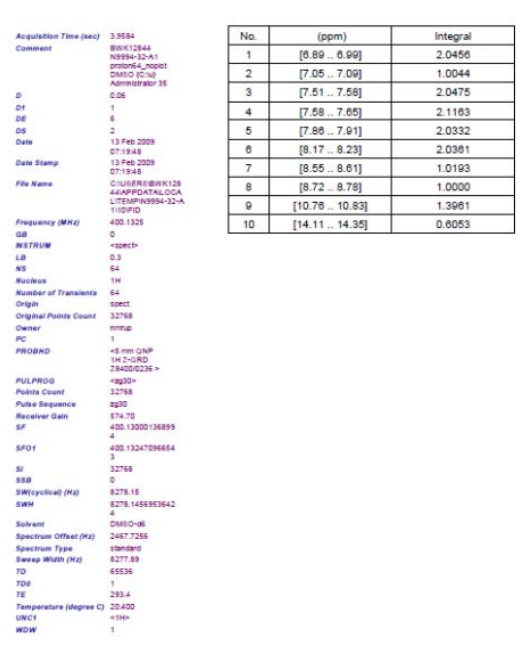

${ }^{1} \mathrm{H} \mathrm{NMR}\left(400 \mathrm{MHz}, \mathrm{DMSO}-\mathrm{d}_{\mathrm{f}}\right) \hat{0} 14.22$ (br s, $\left.1 \mathrm{H}\right), 10.83-10.76$ (m, 1H), 8.75 (d, $\left.J=9.3 \mathrm{~Hz}, 1 \mathrm{H}\right), 8.58(\mathrm{~d}, J=7.1 \mathrm{~Hz}, 1 \mathrm{H})$ $8.23-8.17(\mathrm{~m}, 2 \mathrm{H}), 7.91-7.86(\mathrm{~m}, 2 \mathrm{H}), 7.65-7.58(\mathrm{~m}, 2 \mathrm{H}), 7.58-7.51(\mathrm{~m}, 2 \mathrm{H}), 7.09-7.05(\mathrm{~m}, 1 \mathrm{H}), 6.99-6.89(\mathrm{~m}, 2 \mathrm{H})$
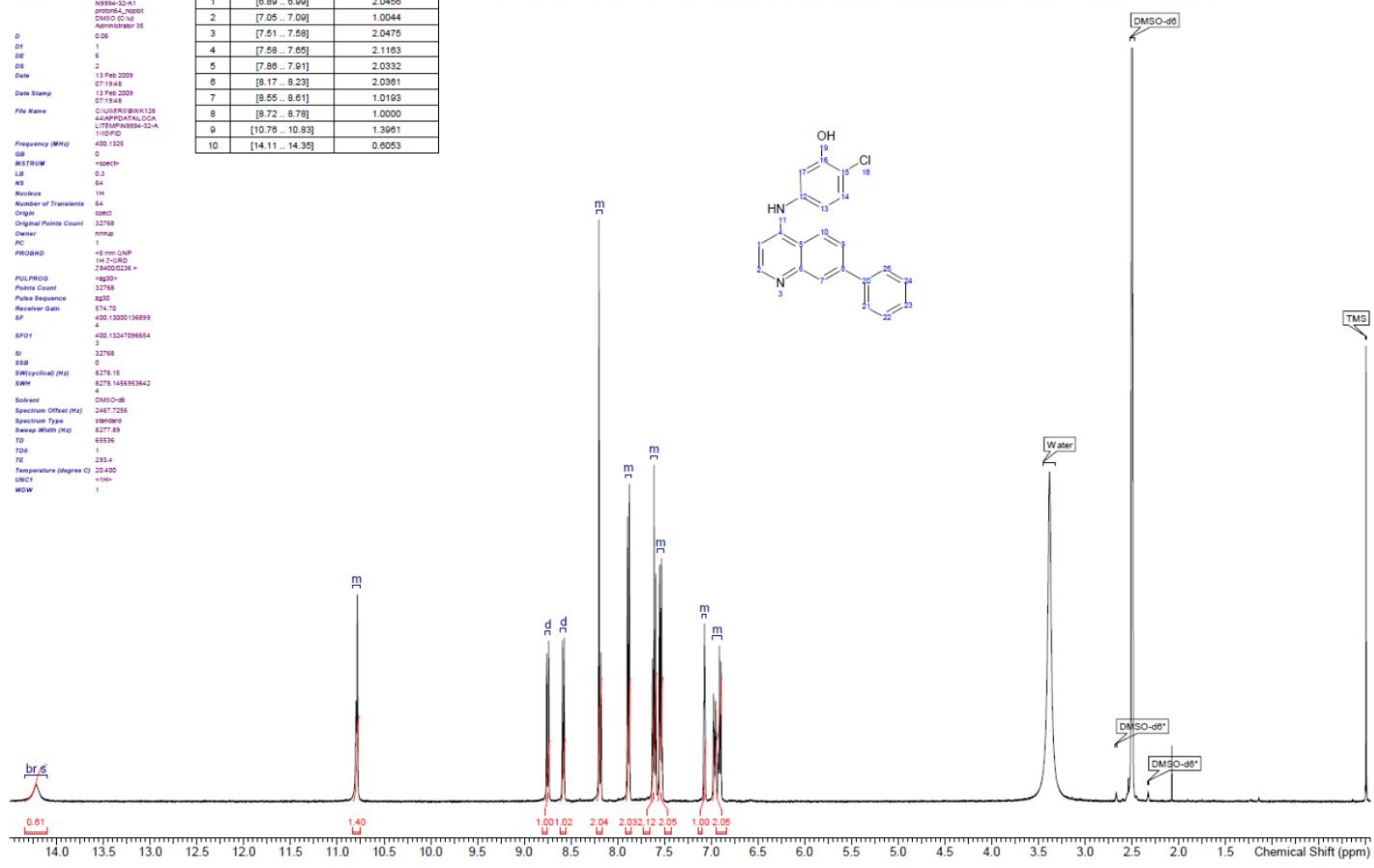

\section{Synthesis of N-(7-phenylquinolin-4-yl)benzo[d]thiazol-5-amine (4)}<smiles>Clc1ccnc2cc(-c3ccccc3)ccc12</smiles><smiles>Nc1ccc2scnc2c1</smiles>

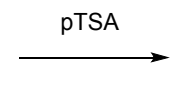<smiles>c1ccc(-c2ccc3c(Nc4ccc5scnc5c4)ccnc3c2)cc1</smiles> 
A solution of 4-chloro-7-phenylquinoline (12 mg, $0.050 \mathrm{mmol}$ ) (see Chem. Commun., 2017, 53, 13063-13066), benzo[d]thiazol-5-amine $(7.5 \mathrm{mg}, 0.050 \mathrm{mmol})$, and $p$-toluenesulfonic acid monohydrate $(1.9 \mathrm{mg}, 0.010 \mathrm{mmol})$ in dimethyl sulfoxide (DMSO) $(1 \mathrm{~mL})$ was irradiated in a microwave reactor at $80{ }^{\circ} \mathrm{C}$ for $30 \mathrm{~min}$. Purification of the crude material using reverse phase HPLC [30-60\% acetonitrile:water (0.1\% TFA modifier), $30 \mathrm{~mm}$ Luna column, $47 \mathrm{~mL} / \mathrm{min}$ ] gave N-(7-phenylquinolin-4-yl)benzo[d]thiazol-5-amine (4) (18 mg, 78\%) (mono TFA salt). LCMS $(m / z):[\mathrm{M}+\mathrm{H}]^{+}$calc'd for $\mathrm{C}_{22} \mathrm{H}_{16} \mathrm{~N}_{3} \mathrm{~S}, 354.1$; found, 354.0. ${ }^{1} \mathrm{H}$ NMR $\left(400 \mathrm{MHz}\right.$, DMSO- $\left.{ }_{6}\right) \delta \mathrm{ppm}$ 14.17 (br s, 1H), 11.07 (s, 1H), $9.55(\mathrm{~s}, 1 \mathrm{H}), 8.83(\mathrm{~d}, J=9.1 \mathrm{~Hz}, 1 \mathrm{H}), 8.57$ (dd, $J=7.1,2.0 \mathrm{~Hz}$, 1H), $8.41(\mathrm{~d}, J=8.6 \mathrm{~Hz}, 1 \mathrm{H}), 8.29-8.20(\mathrm{~m}, 3 \mathrm{H}), 7.95-7.88(\mathrm{~m}, 2 \mathrm{H}), 7.68-7.52(\mathrm{~m}, 4 \mathrm{H}), 6.94$ $-6.88(\mathrm{~m}, 1 \mathrm{H})$. HRMS $(\mathrm{m} / \mathrm{z}):[\mathrm{M}+\mathrm{H}]^{+}$calc'd for $\mathrm{C}_{22} \mathrm{H}_{16} \mathrm{~N}_{3} \mathrm{~S}, 354.1065$; found, 354.1065. LCMS purity $=100 \%$ by UV at $214 \mathrm{~nm}$.

${ }^{1} \mathrm{H}$ NMR of $\mathbf{4}$

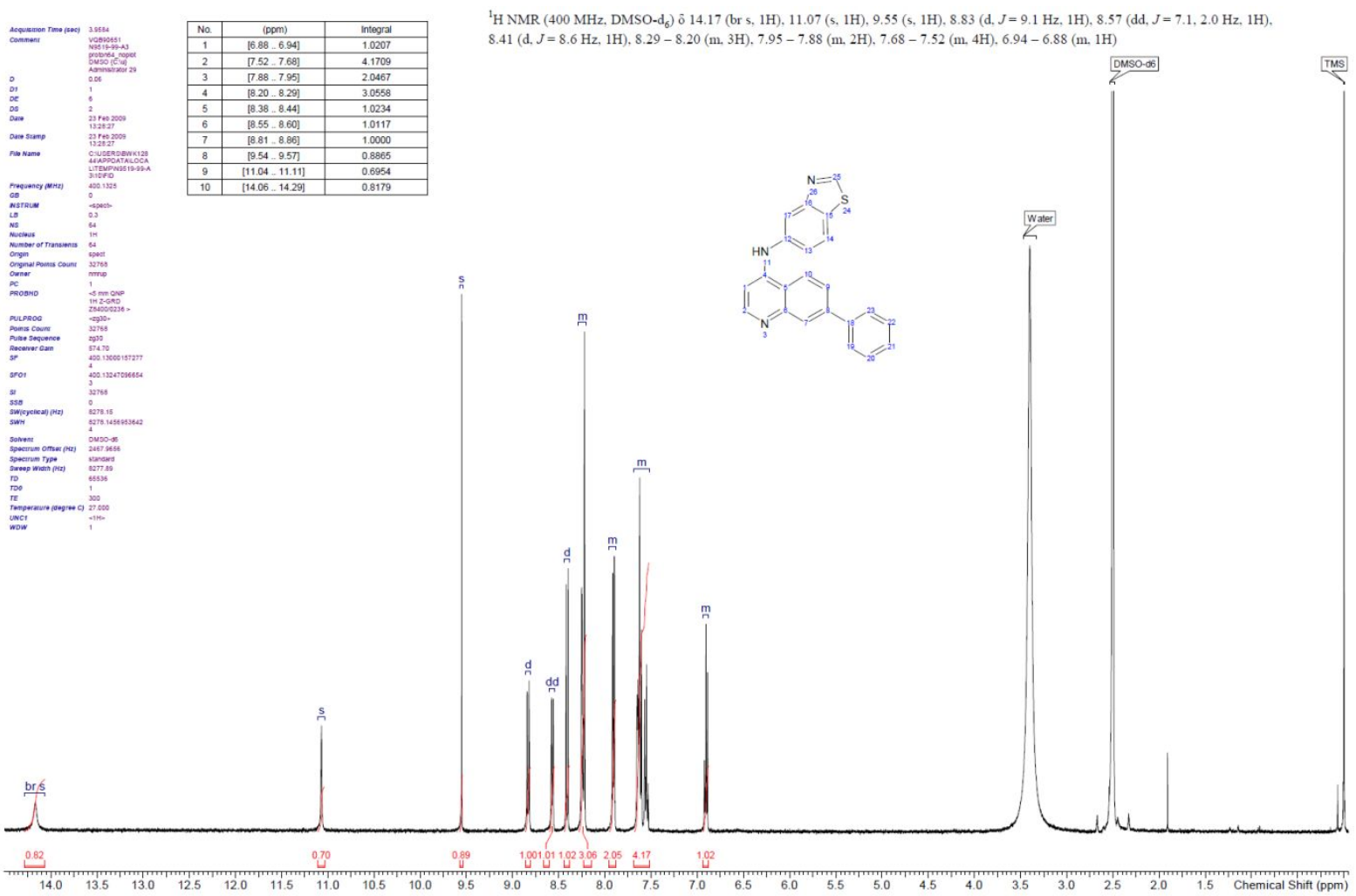


Synthesis of 9H-fluoren-9-yl)methyl (2-((6-(azidomethyl)tetrahydro-2H-pyran-2yl)oxy)ethyl)carbamate (14)
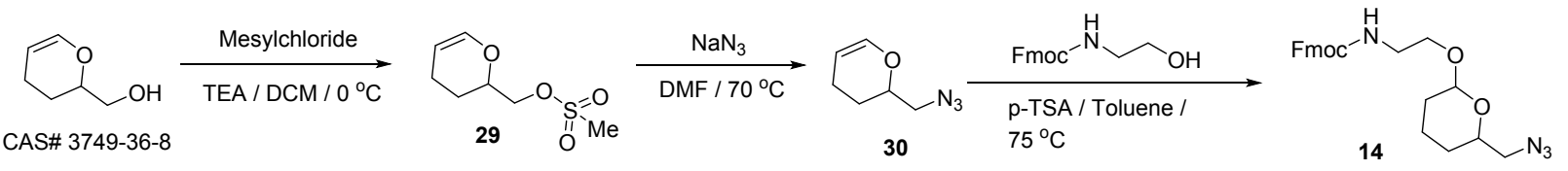

1g (3,4-dihydro-2H-pyran-2-yl)methanol and $4.8 \mathrm{~mL}$ TEA were added into $10 \mathrm{~mL}$ of DCM, and the solution was cooled to $0{ }^{\circ} \mathrm{C}$ under nitrogen atmosphere. $1 \mathrm{~mL}$ Mesylchloride was then added dropwise at $0{ }^{\circ} \mathrm{C}$, and the mixture was stirred for $3 \mathrm{~h}$ at $0{ }^{\circ} \mathrm{C}$. Reaction progress was monitored by TLC. After the reaction is completed, the reaction mixture was quenched with ice water and basified by adding sat. $\mathrm{NaHCO}_{3}$ solution. The product was extracted by DCM $(30 \mathrm{~mL} \times 2)$. Organic layer was separated, washed with brine, dried over $\mathrm{Na}_{2} \mathrm{SO}_{4}$, and concentrated under reduced pressure to give crude product, and the crude product 29 was used in next step without further purification.

The crude 29 from previous reaction was dissolved in $10 \mathrm{~mL} \mathrm{DMF}$, then added $3.4 \mathrm{~g}$ sodium azide under nitrogen atmosphere. The reaction mixture was stirred at 60 to $70{ }^{\circ} \mathrm{C}$ for $36 \mathrm{~h}$. Reaction progress was monitored by TLC. After the reaction is completed, the reaction mixture was cooled and poured into ice water. The product was extracted by diethylether $(20 \mathrm{~mL} \times 2)$. The organic layer was separated, dried over $\mathrm{Na}_{2} \mathrm{SO}_{4}$, and concentrated under reduced pressure to give crude product, and the crude product $\mathbf{3 0}$ was used in next step without further purification.

The crude $\mathbf{3 0}$ from previous reaction was dissolved in $10 \mathrm{~mL}$ toluene, then added $0.4 \mathrm{~g}$-TSA and 1g Fmoc glycinol at RT under nitrogen atmosphere. The reaction mixture was stirred at 70 to 80 ${ }^{\circ} \mathrm{C}$ for $5 \mathrm{~h}$. Reaction progress was monitored by TLC. After the reaction is completed, the reaction mixture was cooled and poured into ice water. The product was extracted by ethylacetate $(30 \mathrm{~mL}$ 
$\times 2$ ). The organic layer was separated, washed with brine, dried over $\mathrm{Na}_{2} \mathrm{SO}_{4}$, and concentrated under reduced pressure to give crude product 14. The crude product $\mathbf{1 4}$ was used in next step purified by $100-200 \mathrm{~m}$ silica gel column chromatography using 10-15\% EtOAc in Hexanes as eluent. $\quad 0.1$ g of (9H-fluoren-9-yl)methyl (2-((6-(azidomethyl)tetrahydro-2H-pyran-2yl)oxy)ethyl)carbamate 14 was obtained with overall $2.7 \%$ yield, LCMS purity $=97.64 \%$ at Maxplot, HPLC purity $=97.03 \%$ by UV at $215 \mathrm{~nm}, 97.66 \%$ by UV at $254 \mathrm{~nm}$., as a mixture of isomers. LCMS m/z $=445.53 / 445.52[\mathrm{M}+\mathrm{Na}]^{+} .{ }^{1} \mathrm{H}$ NMR (400 MHz, DMSO-d $\left.\mathrm{d}_{6}\right) \delta \mathrm{ppm} 7.89(\mathrm{~d}$, $J=7.6 \mathrm{~Hz}, 2 \mathrm{H}), 7.69(\mathrm{~d}, J=7.2 \mathrm{~Hz}, 2 \mathrm{H}), 7.42(\mathrm{t}, J=7.2 \mathrm{~Hz}, 2 \mathrm{H}), 7.36(\mathrm{t}, J=7.2 \mathrm{~Hz}, 2 \mathrm{H}), 4.82$ (br, 1H), 4.22-4.31 (m, 3H), $3.85(\mathrm{~m}, 1 \mathrm{H}), 3.63(\mathrm{~m}, 1 \mathrm{H}), 3.25(\mathrm{~m}, 1 \mathrm{H}), 3.38(\mathrm{~m}, 4 \mathrm{H}), 1.74(\mathrm{~m}, 1 \mathrm{H})$, $1.58(\mathrm{~m}, 5 \mathrm{H}), 1.28(\mathrm{~m}, 1 \mathrm{H})$

${ }^{1} \mathrm{H}$ NMR of 14

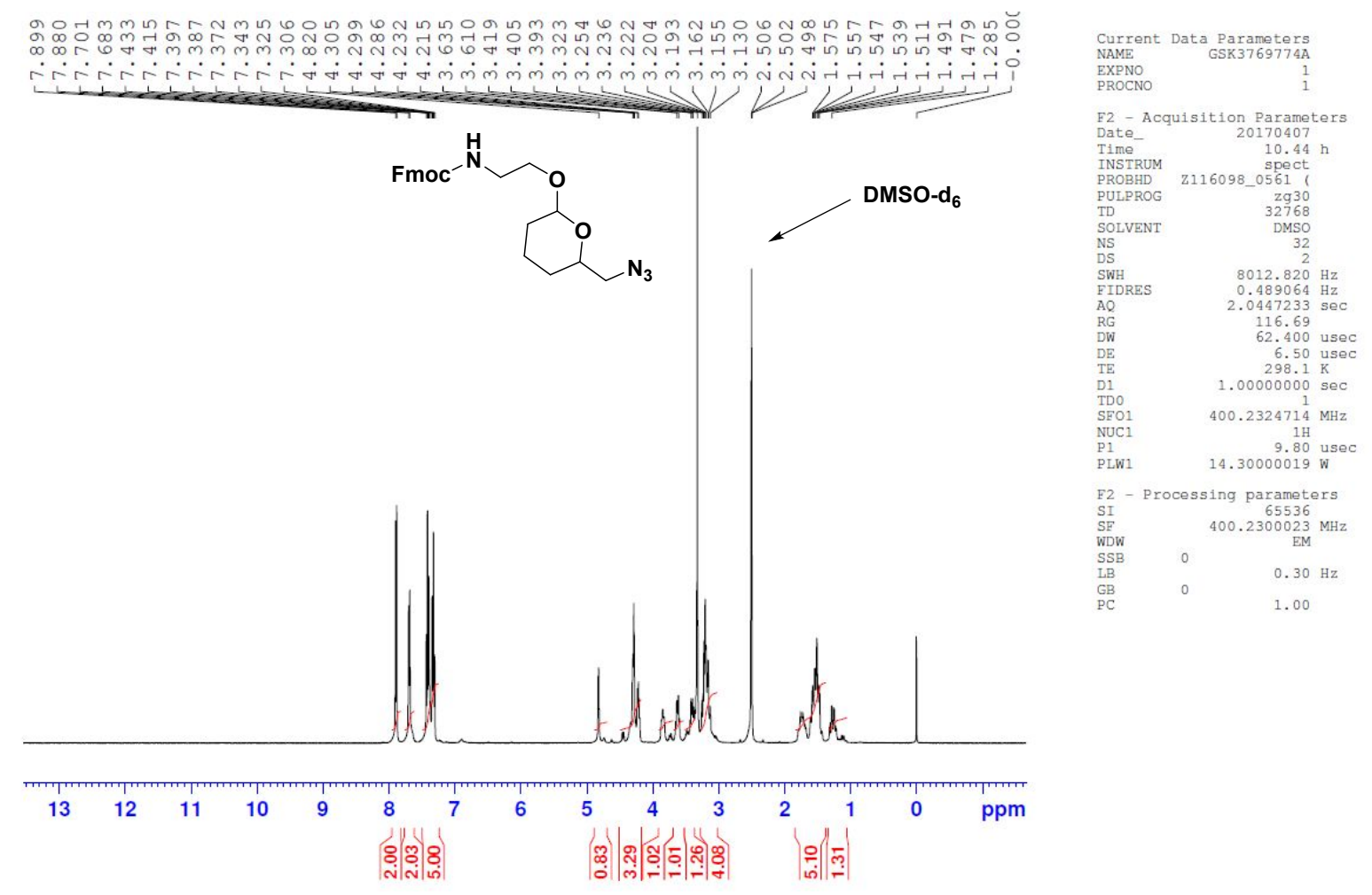




\section{LCMS of 14}

\section{UV Chromatogram}

Detector Type:

PDA

Wavelength Range 1 (nm)

N/A

RT: $0.00-10.00$ SM: $7 G$
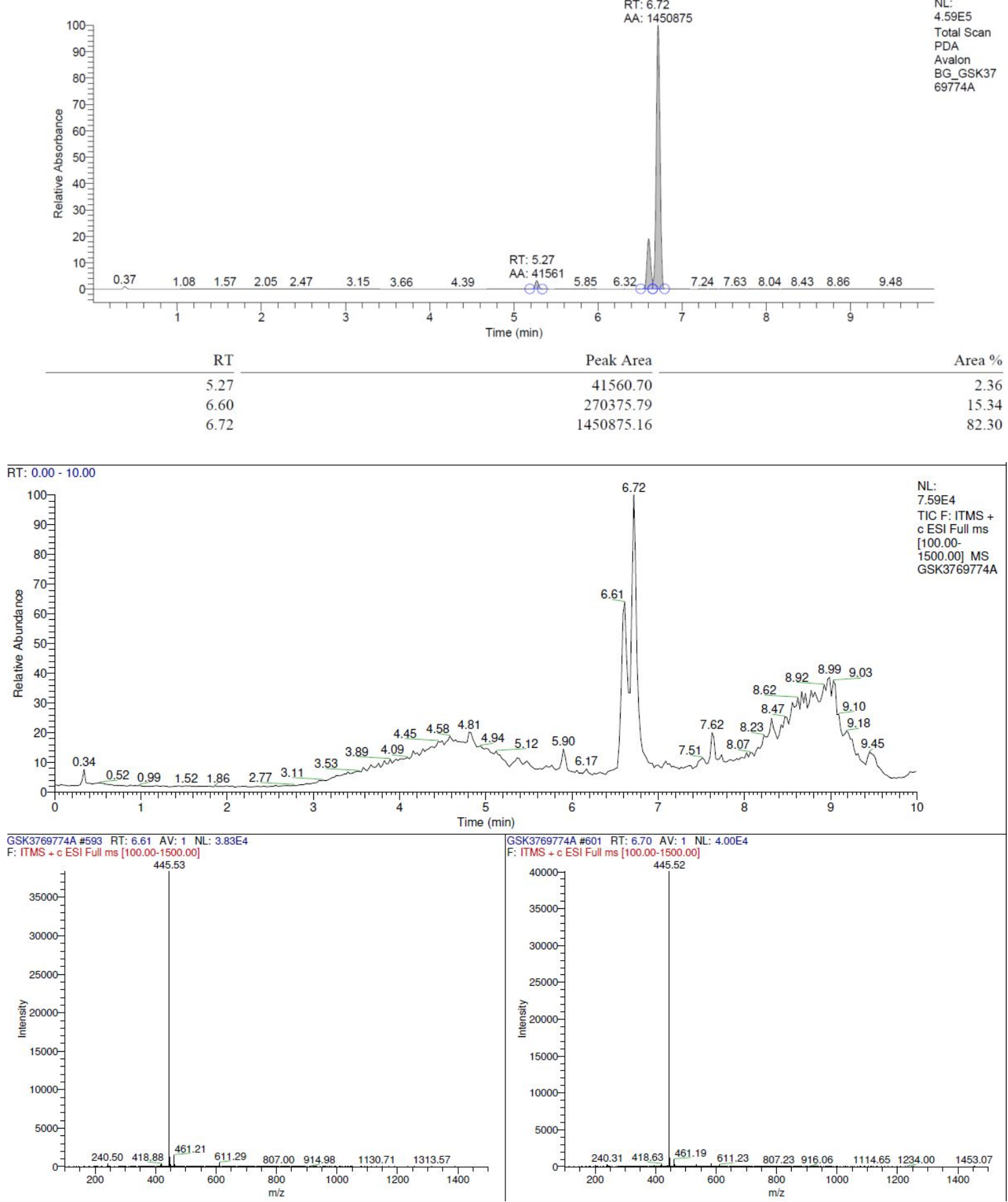


\section{Part III: AS-MS}

LC/MS: The HPLC system was a Thermo Scientific ${ }^{\mathrm{TM}}$ UltiMate $^{\mathrm{TM}} 3000$ Rapid Separation System. The reverse phase column used for the sample analysis was a Kinetex XB-C18 (1.7 $\mu \mathrm{m}$,

$100 \AA \AA, 2.1 \times 50 \mathrm{~mm}$ ) purchased from Phenomenex ${ }^{\circledR}$. Solvent A was $0.1 \%$ formic in $\mathrm{H}_{2} \mathrm{O}$, and solvent $\mathrm{B}$ was $0.1 \%$ formic and $1 \% \mathrm{H}_{2} \mathrm{O}$ in $\mathrm{CH}_{3} \mathrm{CN}$. The elution program was $5 \%$ to $95 \% \mathrm{~B}$ in 2 $\min$ (hold final $0.4 \mathrm{~min}$ ) at $0.6 \mathrm{~mL} / \mathrm{min}$. The mass analysis was carried out on a Thermo Orbitrap (Exactive), a benchtop LC/MS system that delivers high-resolution, accurate-mass (HR/AM) data with fast full-scan capabilities. The ionization source was heated electrospray ionization (HESI). The HESI source Exactive was tuned. The temperature of the probe heater and capillary was kept at $30^{\circ} \mathrm{C}$ and $300{ }^{\circ} \mathrm{C}$, respectively. Ions were collimated using a spray voltage of $3900 \mathrm{~V}$ and an Slens RF voltage of 50 V. Sheath, Aux, and Spare gas were set at 20, and Xcalibur version 4.1.31.9 software (Thermo Fisher Scientific, Inc.) was used for data processing and peak integration. Affinity-MS was used for automatic data analysis. Affinity-MS is a bespoke Microsoft Windowsbased software solution developed by GSK to register, manage, analyze, and report affinity selection mass spectrometry experiments and results.

\section{AS-MS:}

Sample preparation: The lyophilized samples (small molecule mixtures cleaved from DNA) were re-constituted in neat DMSO at a final concentration of $1 \mathrm{mM}$, and then further diluted in selection buffer at $100 \mu \mathrm{M}$ for AS-MS experiments.

Incubation: A total of $2 \mu \mathrm{L}$ of the compound solution in selection buffer was transferred to a 384-well microtiter plate (384 Well Polypropylene Microplates 781201, Greiner Bio-One, Winchester, MA), followed by the addition of $20 \mu \mathrm{L}$ of AS-MS selection buffer with (selection sample) and without $10 \mu \mathrm{M}$ of target protein (RIP2) for the no target control (NTC) sample. The plate was then sealed and the mixture incubated for $1 \mathrm{~h}$ at ambient temperature. These incubation 
mixtures were also used as reference samples that were directly injected into the MS system, not loaded onto the SEC plates. The MS signals from the reference samples were used to compare MS signals from select samples loaded onto SEC columns. Relative Binding Affinity (\%RBA) for cleaved products were then assessed for binding in AS-MS, which indicates that compound recovered in SEC.

Separation of bound and unbound compounds: After incubation of the target protein for $\sim 1 \mathrm{~h}$ to achieve full binding of compounds in the mixtures in equilibrium, the incubation solutions were transferred to a 384-well SEC plate with pinholes in the well bottoms (Fisher Scientific, Multiscreen HTS 384-well filter plates, $0.45 \mu \mathrm{M}$ Durapore, Cat\# MZHVN0W50). The SEC plate was prepared with Bio-Gel P10 fine resin (Bio-Rad 150-4144) and spun at $1054 \times \mathrm{g}$ in a centrifuge (5810R, Eppendorf, Germany) for $3 \mathrm{~min}$ at $4{ }^{\circ} \mathrm{C}$. The recovered NTC, selection samples, and reference (w/o SEC) were analyzed by LC/MS mentioned above.

AS-MS data analysis: Data processing was accomplished with Affinity-MS, a custom automated software solution developed by GSK. The extracted ion chromatogram (XIC) peak areas were used for data analysis. The test compounds were designated as True, False, or Indeterminate in the data analysis by comparing MS signals from the reference, NTC, and selection samples. A True binder was found in the protein-containing sample but absent in the control/NTC samples. On the other hand, the compound found in the protein fraction was also detected in the control/NTC samples. This compound passed through the SEC gel column in the absence of the protein and, therefore, is considered a false-positive hit. The relative binding affinity (RBA\%) was calculated as: (MS signal from Selection samples - MS signal from NTC samples)/MS signal from Reference samples $\times 100 \%$ 
The AS-MS data for THP linker compound $\mathbf{2 1}$ is shown below as an example of how the compound is identified as a binder. LC/MS analysis of the reference sample indicated that compound $\mathbf{2 1}$ is the major cleaved product, which also includes some minor side products and originally produced intermediates (Figure S-3-1). The cleaved products were screened as small molecule mixtures by off-line AS-MS. Ligands that engage the target protein were identified by comparing their $\mathrm{m} / \mathrm{z}$ values (mainly, molecular mass $+\mathrm{H}$ or $\mathrm{Na}$ ) to the molecular masses of the enumerated compounds from that particular well using Affinity-MS software. The extracted ion chromatograms (XIC) of compound 21 in the reference, NTC, and selection samples are shown in Figure S16, which depicts it is a True binder as compound $21(\mathrm{~m} / \mathrm{z} 440.15)$ is found in the protein-containing sample but absent in the control/NTC samples. The RBA\% of compound 21 is $29.7 \%$ (Figure S17).

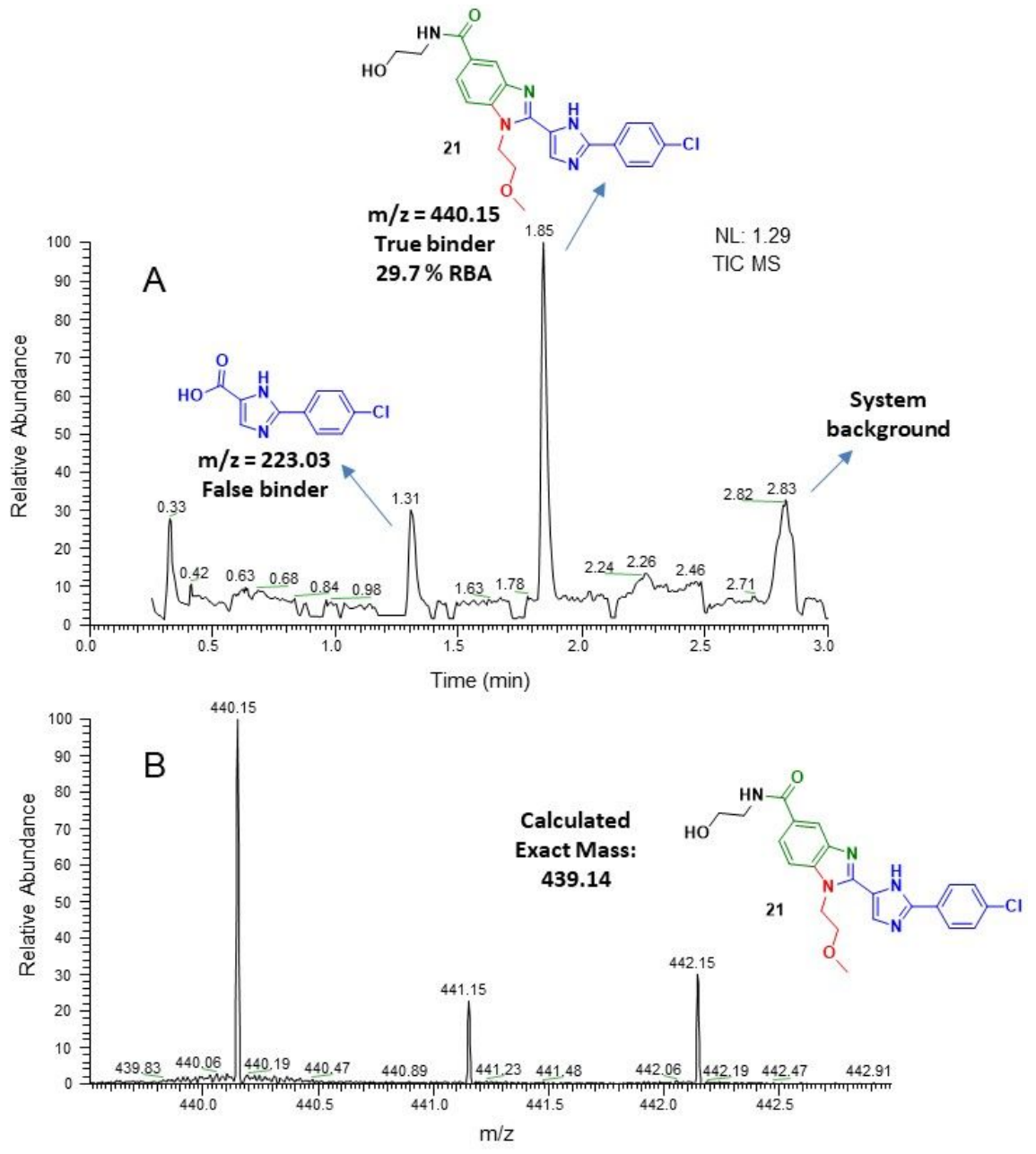




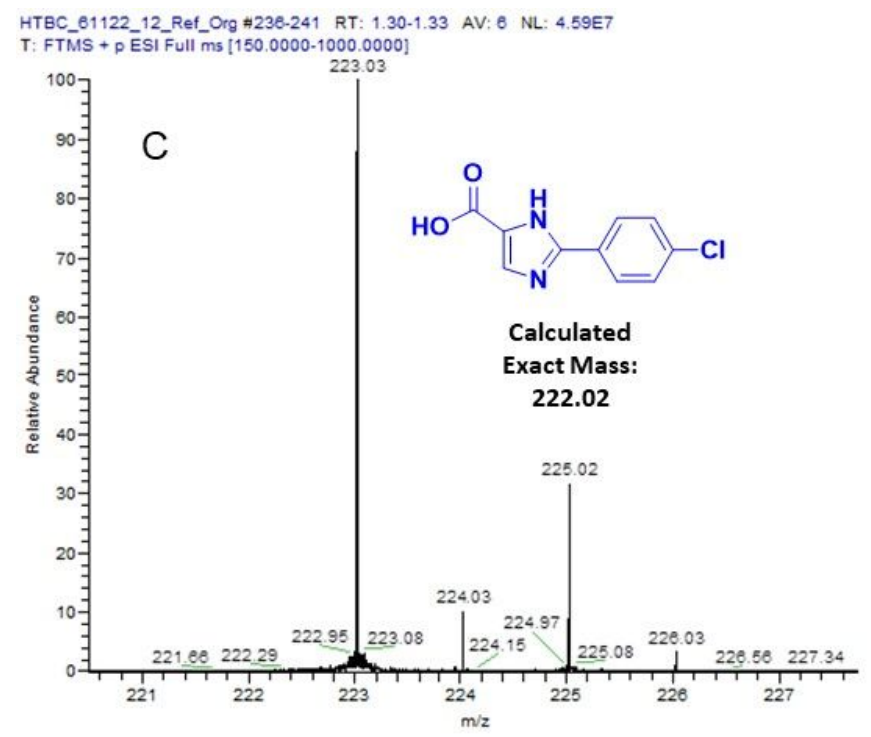

Figure S16. Total ion chromatogram (TIC) of the reference sample for the THP linker compound showing that compound $\mathbf{2 1}$ is the major cleaved product (A). The positive ion of the ESI mass spectrum of the peak at $1.85 \mathrm{~min}(\mathrm{~B})$. Two peaks were separated by $2 \mathrm{~m} / \mathrm{z}$ units with a peak height ratio of $3: 1$, indicating that the molecule contains 1 chlorine atom. The positive ion of the ESI mass spectrum of the peak at $1.31 \mathrm{~min}(\mathrm{C})$, similar to compound $\mathbf{2 1}$, it must contain 1 chlorine atom since two peaks were separated by $2 \mathrm{~m} / \mathrm{z}$ units with a peak height ratio of $3: 1$. 


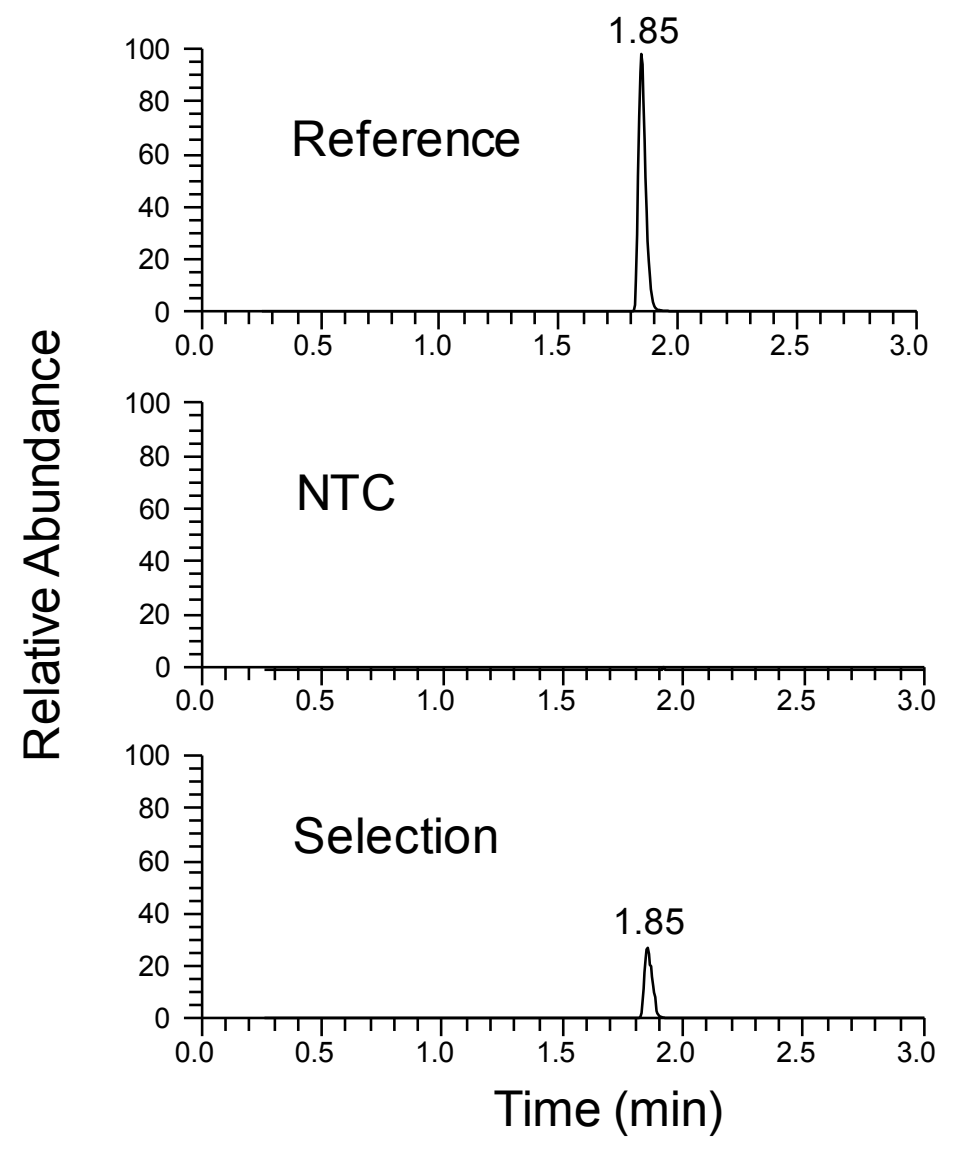

\begin{tabular}{|c|c|c|c|}
\hline Compound 21 & Retention time (min) & Peak Area & \multirow{2}{*}{ RBA (\%) } \\
\hline Reference & 1.85 & $5.15 . \mathrm{E}+08$ & \multirow{2}{*}{$29.7 \%$} \\
\hline NTC & 1.85 & $3.00 . \mathrm{E}+05$ & \\
\hline Selection sample & 1.85 & $1.54 . \mathrm{E}+08$ & \\
\hline
\end{tabular}

Figure S17. Identification of RIP2 binder 21 from the released small molecule mixture by ASMS. Extracted ion chromatograms (XIC) shows compound 21 in the reference, NTC, and selection samples. The \%RBA is calculated based on the peak area in the XIC of each sample. 
Similarly, the RBAs of compounds 11 and 12 (after cleavage, shown in Figure S18) are calculated as following based on the peak area in the XIC. Other peaks including the peak at RT 2.86 min are not related to the desired compounds or side products and they were not observed in the LC/MS spectra including TIC and XIC after SEC.

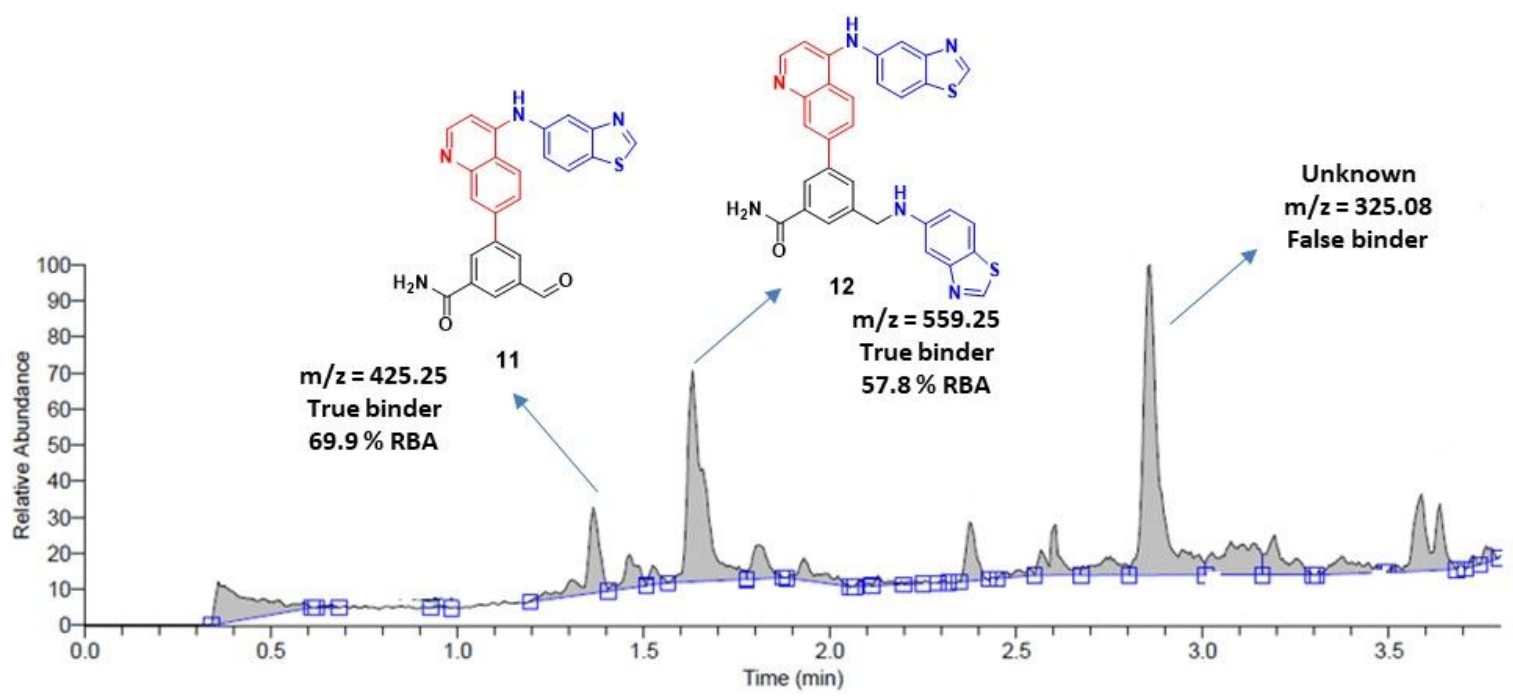

\begin{tabular}{|c|c|c|c|}
\hline Compound 11 & Retention time (min) & Peak Area & RBA (\%) \\
\hline Reference & 1.37 & $2.62 \mathrm{E}+06$ & \multirow{3}{*}{$69.9 \%$} \\
\hline NTC & 1.37 & $1.73 \mathrm{E}+05$ & \\
\hline Selection sample & 1.37 & $2.00 \mathrm{E}+06$ & \\
\hline Compound 12 & Retention time (min) & Peak Area & RBA (\%) \\
\hline Reference & 1.64 & $1.67 \mathrm{E}+06$ & \multirow{3}{*}{$57.8 \%$} \\
\hline NTC & 1.64 & $1.12 \mathrm{E}+05$ & \\
\hline Selection sample & 1.64 & $1.07 E+06$ & \\
\hline
\end{tabular}

Figure S18. Identification of RIP2 binders 11 and 12 from the released small molecule mixture by AS-MS. Extracted ion chromatograms (XIC) shows compound $\mathbf{1 1}$ and $\mathbf{1 2}$ in the reference, NTC, and selection samples. The RBAs are calculated based on the peak area in the XIC of each sample. 